LUCIANO ONDIR FREIRE

DESENVOLVIMENTO DE UMA ARQUITETURA DE CONTROLE DESCENTRALIZADA PARA VEÍCULOS SUBMARINOS BASEADA EM CAN, ARM E ENGENHARIA DE SISTEMAS - CANARMES 


\title{
DESENVOLVIMENTO DE UMA ARQUITETURA DE CONTROLE DESCENTRALIZADA PARA VEÍCULOS SUBMARINOS BASEADA EM CAN, ARM E ENGENHARIA DE SISTEMAS - CANARMES
}

\author{
Dissertação apresentada à Escola \\ Politécnica da Universidade de São \\ Paulo para obtenção do Título de \\ Mestre em Engenharia.
}

São Paulo 2013 


\title{
DESENVOLVIMENTO DE UMA ARQUITETURA DE CONTROLE DESCENTRALIZADA PARA VEÍCULOS SUBMARINOS BASEADA EM CAN, ARM E ENGENHARIA DE SISTEMAS - CANARMES
}

\author{
Dissertação apresentada à Escola \\ Politécnica da Universidade de São \\ Paulo para obtenção do Título de \\ Mestre em Engenharia.
}

Área de Concentração: Engenharia de Controle e Automação Mecânica.

Orientador: Prof. Dr. Ettore Apolônio de Barros

São Paulo 2013 
Este exemplar foi revisado e corrigido em relação à versão original, sob responsabilidade única do autor e com a anuência de seu orientador.

São Paulo, 16 de agosto de 2013.

Assinatura do autor

Assinatura do orientador

FICHA CATALOGRÁFICA

Freire, Luciano Ondir

Desenvolvimento de uma arquitetura de controle descentralizada para veículos submarinos baseada em CAN, ARM e engenharia de sistemas - CANARMES / L.O. Freire. -- versão corr. -- São Paulo, 2013.

$104 \mathrm{p}$.

Dissertação (Mestrado) - Escola Politécnica da Universidade de São Paulo. Departamento de Engenharia Mecatrônica e de Sistemas Mecânicos.

1.Submersíveis não tripulados 2.Robôs 3.Arquitetura de controle I.Universidade de São Paulo. Escola Politécnica. Departamento de Engenharia Mecatrônica e de Sistemas Mecânicos II.t. 


\section{RESUMO}

Os veículos submarinos não tripulados tem uma importância crescente devido à sua flexibilidade e baixo custo. Devido à sua complexidade intrínseca, eles requerem diversas competências diferentes para serem desenvolvidos e permitem realizar pesquisas em vários campos do conhecimento. No contexto de uma universidade, que possui pessoal heterogêneo e de alta rotatividade, faz-se mister adotar uma organização que permita que os esforços de cada aluno possam ser reusados pelos outros, de modo as atividades de pesquisa possam avançar com pouca perda de tempo e retrabalho. Tal necessidade pode ser respondida pela aplicação de conceitos da engenharia de sistemas, tais como modularidade, separação formal entre soluções tecnológicas e necessidades, classificação funcional, critérios para escolha do método de desenvolvimento, uso de referencial normativo técnico, plano tecnológico, integração, verificação e validação e gerenciamento de configurações. Este trabalho se limita a desenvolver uma arquitetura de controle, observando os conceitos de engenharia de sistemas, aplicada a um AUV. É feita uma comparação com outras arquiteturas similares do estado da arte e mostram-se resultados de testes em piscina para esta arquitetura. É mostrado também que foi possível estabelecer a continuidade do desenvolvimento por outros alunos, validando a utilidade da metodologia. Conclui-se que, para aumentar a eficiência da pesquisa universitária, é necessário observar aspectos gerenciais e institucionais além dos aspectos técnicos ao conceber soluções técnicas.

Palavras-chave: Submersíveis não tripulados. Robôs. Arquitetura de controle. 


\begin{abstract}
The unmanned underwater vehicles have a growing position due to their flexibility and low cost. Due to their inherent complexity, they require many different skills to be developed and they allow conducting research in various fields of knowledge. In the context of a university, which has heterogeneous staff and high turnover, there is the need of adopting an organization that allows the efforts of each student be reused by others, so research activities can proceed with little loss of time and rework. This need can be answered by the application of system engineering concepts such as modularity, formal separation between technology solutions and needs, functional classification, criteria for the choice of development method, use of technical reference standard, technological plan, integration, verification and validation and configuration management. This work is limited to development of a control architecture, observing the concepts of systems engineering, applied to an AUV. A comparison is made with other similar architectures in the state of the art and shows up test results in the pool for this architecture. It is also shown that it was possible to keep the development by other students, validating the utility of the methodology. It is concluded that in order to increase the efficiency of university research, it must be observed managerial and institutional aspects beyond the technical aspects when designing technical solutions.
\end{abstract}

Keywords: Underwater unmanned vehicles. Robots. Control architecture. 


\section{SUMÁRIO}

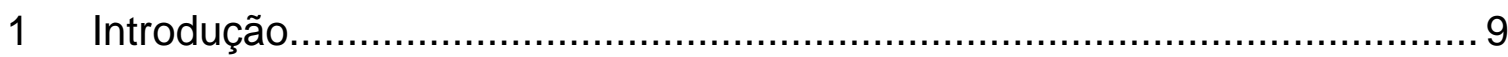

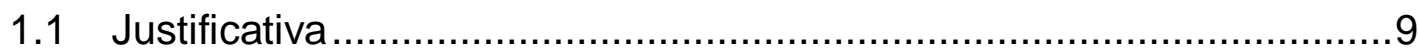

1.2 Objetivos gerais e específicos ......................................................

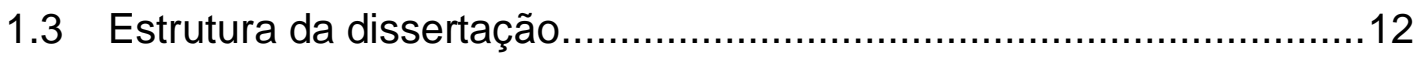

2 Revisão bibliográfica do estado da arte................................................. 13

2.1 Arquiteturas de controle de robôs Móveis - Aplicações em AUVs .....13

2.2 Evolução tecnológica durante o período de estudo .............................18

2.3 Arquiteturas de controle de AUV notáveis .......................................19

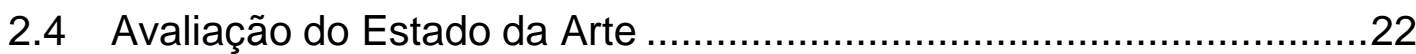

3 Aspectos da Engenharia de Sistemas aplicáveis ao Desenvolvimento de uma Arquitetura de Controle para um AUV ....

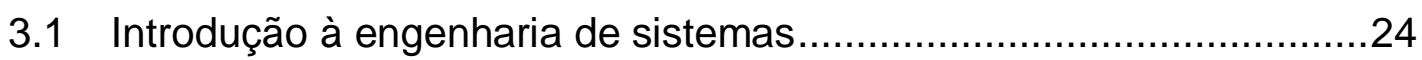

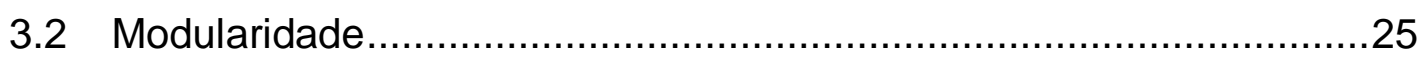

3.3 Separação formal entre soluções tecnológicas e necessidades ........27

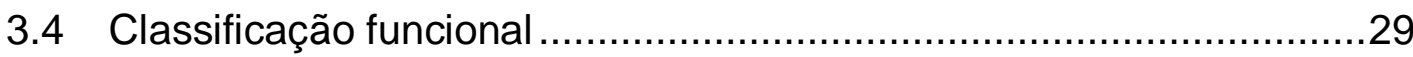

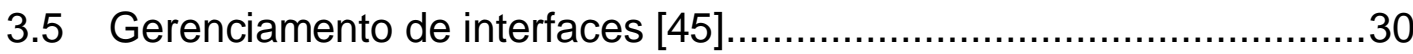

3.6 Decisão sobre o método de desenvolvimento - reuso / fazer / comprar 32

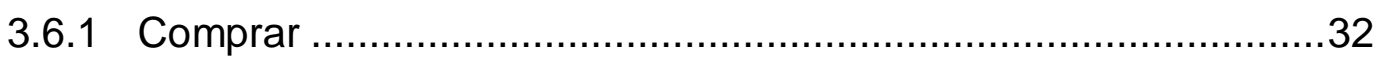

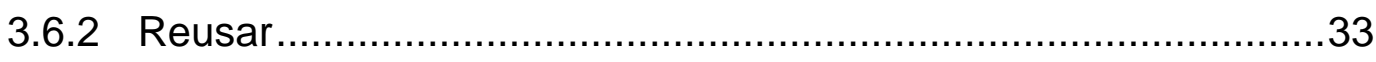

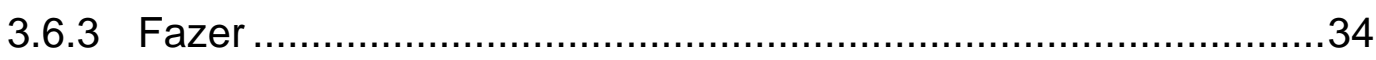

3.7 Escolha de referencial normativo técnico …….................................

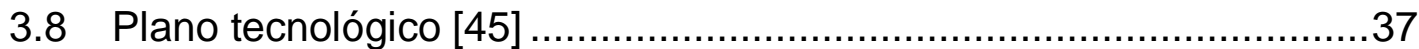

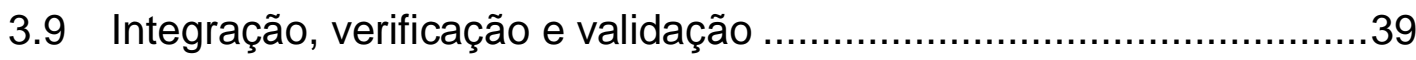

3.10 Gerenciamento de configurações ............................................ 41

3.11 Considerações finais sobre a engenharia de sistemas ...................42

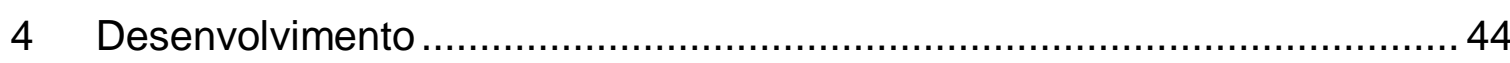

4.1 Estudo de caso do Laboratório de Veículos não Tripulados ...............44

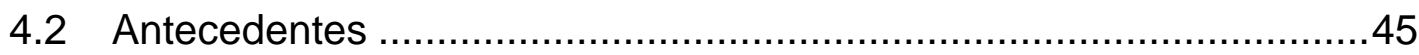

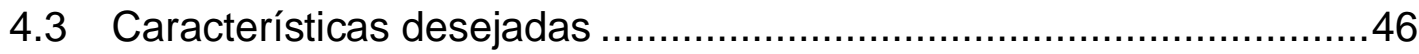

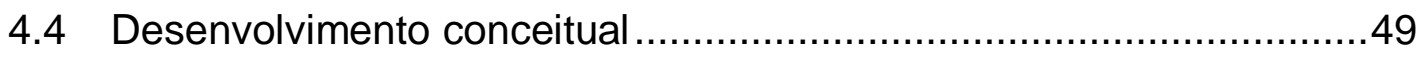

4.4.1 Escolha do método de desenvolvimento ...................................49 


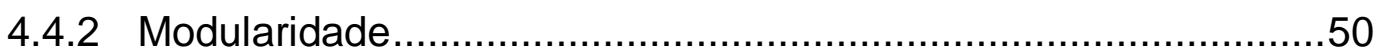

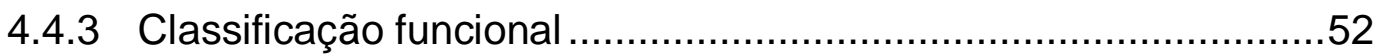

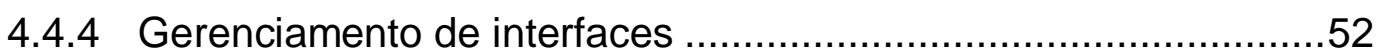

4.4.5 Integração, verificação e validação ............................................52

4.4.6 Gerenciamento de configurações .............................................53

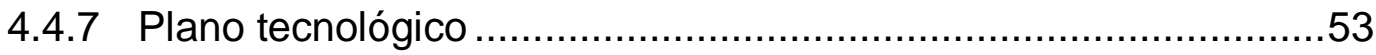

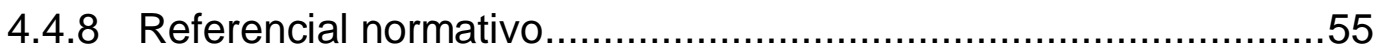

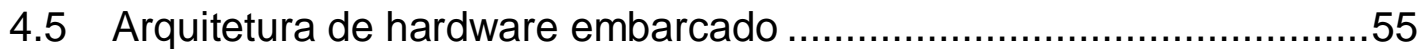

4.5.1 Circuitos de condicionamento e conversão de sinais ....................57

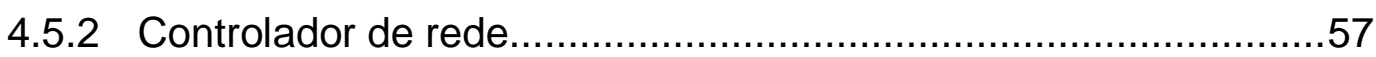

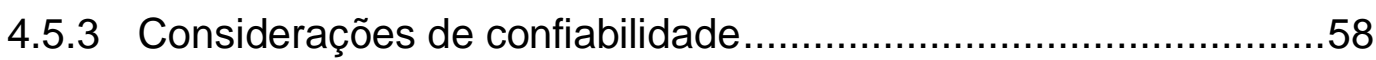

4.5.4 Considerações de robustez mecânica.........................................60

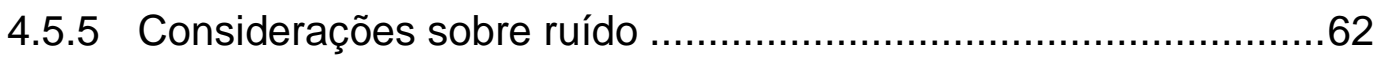

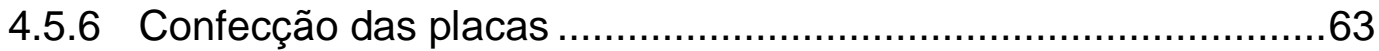

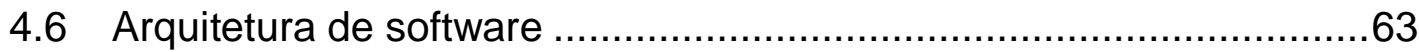

4.6.1 Camada de interação com periféricos .......................................66

4.6.2 Camada de comunicação (memória compartilhada) .....................70

4.6.3 Camada de gerenciamento da missão ........................................71

4.7 Comparação com arquiteturas Notáveis ...........................................71

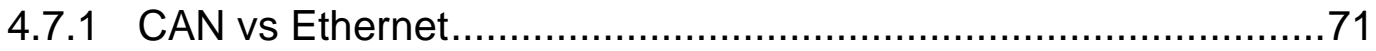

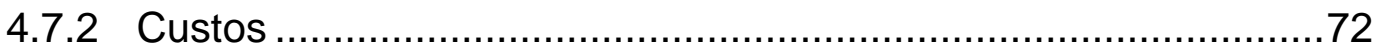

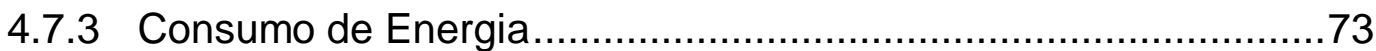

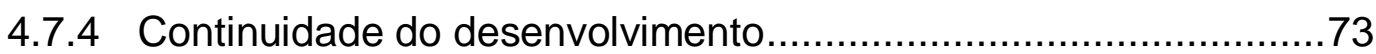

4.7.5 Facilidade de desenvolvimento .................................................

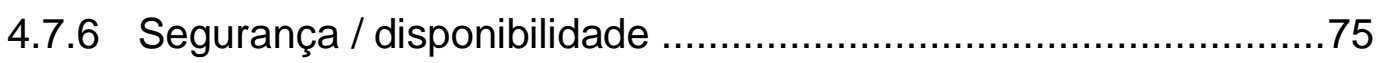

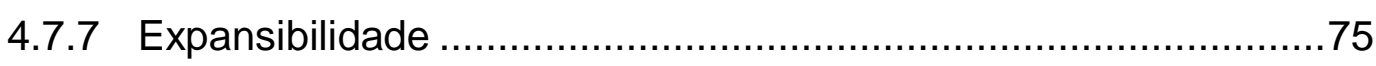

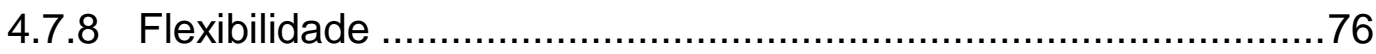

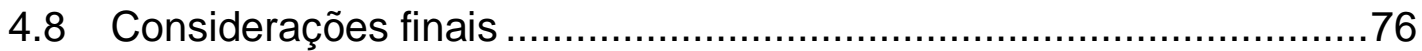

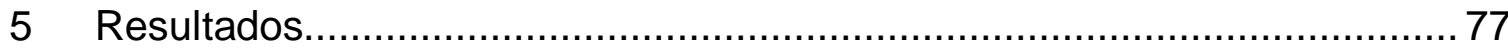

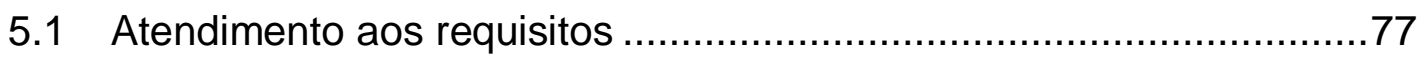

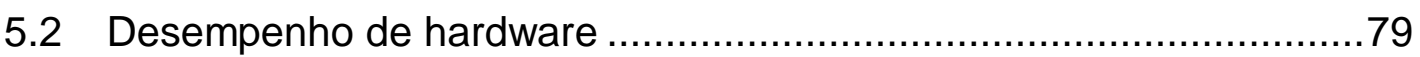

5.3 Validação em piscina do veículo ................................................... 79

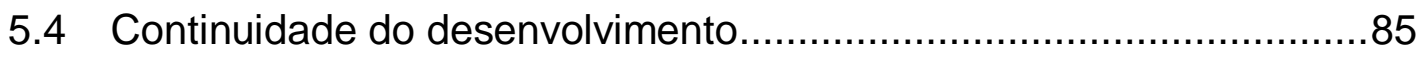

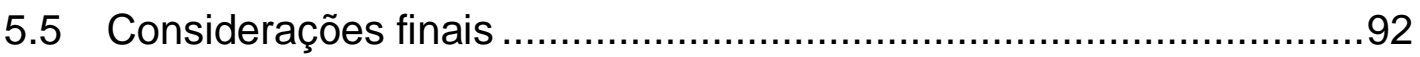




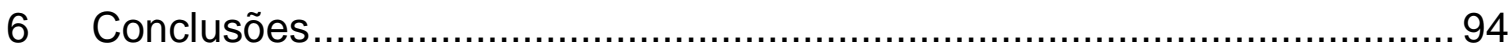

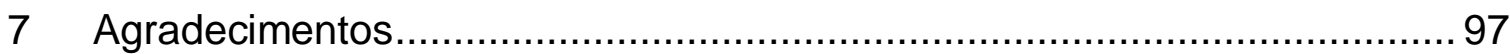

Apêndice A - Convenção de Nomes e Definições ......................................... 98

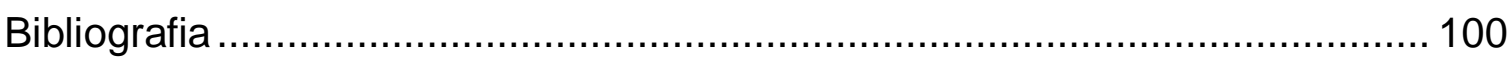




\section{LISTA DE ABREVIATURAS E SIGLAS}

ADC Conversor analógico-digital

ARM7 Advanced RISC Machines versão 7

AUV Autonomous Underwater Vehicle

A/D Analógico-digital

CAN Rede de área para controle

$\mathrm{Cl} \quad$ Circuito integrado

DAC Conversor digital-analógico

D/A Digital-analógico

DSAAV Distributed Software Architecture for Autonomous

Vehicles

FAT Tabela de alocação de arquivos. File Allocation Table

GESAM Generic and Extensible Software Architecture for Mobots

HILS Hardware in-the-loop simulation

IHM Interface homem-máquina

IMU Inertial Measurement Unit

LIPO Lítio-polímero (bateria)

MIPS Mega Instructions Per Second

MISRA Motor Industry Software Reliability Association

PCB Placa de circuito impresso

PWM Modulação por largura de pulso

RF Rádio frequência

RPM rotações por minuto

RTW Real-Time Workshop

RC Rádio controle

RF Rádio Frequência

ROV Remotely Operated Vehicle

SMD Dispositivo montado sobre superfície

SPI Interface serial com periféricos

TCP-IP Transmission Control Protocol/Internet Protocol

TTL Lógica transistor-transistor

UDP User Datagram Protocol 


\section{INTRODUÇÃO}

Este capítulo visa contextualizar o presente trabalho, apresentando a relevância do tema, os objetivos deste trabalho e a estrutura do texto da dissertação.

\subsection{Justificativa}

Este trabalho analisa o projeto de um componente crítico dos veículos autônomos submarinos, AUVs, que é a arquitetura de controle.

Os AUVs têm conquistado um mercado cada vez maior nas áreas de exploração econômica, pesquisa científica e missões militares, nos cenários oceânicos, devido à sua flexibilidade e baixo custo de suas operações se comparado às soluções mais tradicionais. Devido à sua operação não assistida, estes veículos incluem um sistema de controle embarcado relativamente sofisticado.

Nos últimos 50 anos, veículos autônomos submarinos, conhecidos pela sigla AUVs têm aumentado sua participação nas atividades econômicas. Eles oferecem vantagens tais como a habilidade de agir como plataformas que podem carregar sensores de levantamento hidrográfico, obtendo resultados de alta qualidade, livres de ruído da superfície oriundos do movimento de um navio, por exemplo, que seria necessário no caso da utilização de meios alternativos tais como sensores rebocados ou veículos tele-operados (ROVs). Para algumas aplicações, eles oferecem vantagens econômicas e possibilidades de multiplicação rápida. Particularmente, o alto custo de manter um navio no mar para conduzir um levantamento leva à procura de soluções que não envolvam navios de superfície. Adicionalmente, AUVs estão se tornando bem consolidados em várias aplicações, em especial de uso militar e de uso acadêmico.

Por outro lado, dada a natureza interdisciplinar do projeto de AUVs e sua crescente complexidade, seu desenvolvimento é um campo fértil para a aplicação de ideias oriundas da engenharia de sistemas. Mesmo no caso de pequenos veículos desenvolvidos por universidades, existem problemas de engenharia mecânica (vasos de pressão e selos), engenharia naval (arranjo, hidrodinâmica e integração casco - motor - hélice), engenharia elétrica (atuadores, distribuição e armazenamento de energia), engenharia da computação (processadores e redes de dados), engenharia de controle (algoritmos de controle e arquitetura de controle) e engenharia de software (drivers de baixo nível e funções de alto nível) para serem tratados. Esse número de competências e assuntos resulta em uma complexidade 
muito grande, que, comumente impede que uma única pessoa consiga executar um projeto satisfatório de um AUV.

Isso significa que um projeto bem consolidado possui muito desenvolvimento acumulado, feito por diferentes pessoas. Tal projeto não pode ser feito no âmbito de um trabalho acadêmico sem prejuízo da finalidade do mesmo, ainda que o desenvolvimento do AUV seja necessário para a condução da pesquisa.

Entretanto, a própria interdisciplinaridade dos AUVs pode jogar a favor da pesquisa científica, pois uma única plataforma pode servir de base para a produção de conhecimento em vários campos do saber humano. Mas, para isso, o reuso de soluções é fundamental para reduzir custos e tempo. Reuso, por sua vez, requer modularidade e gerenciamento de interfaces, 0 que permite que muitos contribuidores, sejam do meio acadêmico ou não, possam trabalhar em paralelo. Outro requisito fundamental é a flexibilidade, que é ter uma solução técnica que possa facilmente ser modificada para absorver novas funcionalidades.

Um elemento primordial dos AUVs é a arquitetura de controle, pois a execução de uma missão de maneira autônoma pode requerer a avaliação de situações, a tomada de decisões e a execução de ações de maneira automática, o que só pode ser gerado a partir de um sistema sofisticado de hardware e software embarcados. Além disso, em um ambiente universitário, é necessário que a arquitetura de controle seja flexível para que possa incorporar novas funcionalidades.

Esse trabalho propõe uma alternativa à arquitetura de controle apresentada em [1], que é de caráter genérico e extensível para veículos autônomos, usando ferramentas de alta produtividade e que facilitam o processo de certificação junto a autoridades de segurança. Tal arquitetura foi concebida no âmbito de uma empresa de alta tecnologia, o que implica em pessoal altamente capacitado e com baixa rotatividade, tornando essas ferramentas atraentes e muito eficazes. Entretanto, no âmbito do laboratório, a utilização continuada dessa arquitetura esbarrou em fatores humanos, dada a dificuldade de programadores (alunos) subsequentes em usar de maneira proficiente as sofisticadas ferramentas de engenharia de software adotadas para o seu desenvolvimento.

É fundamental levar em conta o perfil do pessoal disponível para a condução das atividades em um laboratório universitário nacional. Do ponto de vista do desenvolvimento, conta-se, basicamente, com dois grupos de recursos humanos: 
um de curto prazo (alunos de graduação, com dedicação média de um ano) e o de médio prazo (alunos de pós-graduação com dedicação que varia entre dois e cinco anos). Cada aluno tem um histórico diferente, tendo habilidades e interesses completamente distintos, exceto por algumas competências básicas do curso de graduação em engenharia. Além disso, a dedicação dos mesmos é comprometida por cursos e atividades de estágio.

Assim sendo, no cenário exposto, é importante se reduzir ao máximo o tempo de aprendizado e treinamento do programador no seu processo de integração à equipe de desenvolvimento e utilização da arquitetura de controle, tentando-se tirar proveito da formação que ele já traz de suas atividades acadêmicas. A experiência indica que empregar ferramentas amplamente conhecidas, apesar de não serem as mais produtivas em ambientes empresariais, resulta em melhor rendimento, haja vista que os alunos podem começar a trabalhar depois de muito pouco tempo de treinamento e, tomados cuidados para assegurar a retenção do conhecimento, o trabalho vai sendo integrado ao capital intelectual do laboratório. Outro fator é a redução do número de tecnologias, pois havendo menor quantidade de componentes diferentes, menos tempo de treinamento é requerido de cada participante.

Concluindo, para que seja desenvolvido continuamente um veículo autônomo submarino dentro de um laboratório universitário existe uma série de condições a serem atendidas. Dentre eles está a existência de uma arquitetura modular com interfaces bem definidas, uso de ferramentas conhecidas e simples, componentes robustos e presentes no mercado local, escolha cuidadosa de tecnologias (levando em conta peso, volume, consumo, complexidade de uso, consolidação no mercado) e é desejável que a arquitetura seja genérica e extensível e atenda a requisitos de segurança.

\subsection{Objetivos gerais e específicos}

Os objetivos gerais são:

a) Propor e analisar, sob o ponto de vista da engenharia de sistemas, os princípios norteadores da condução de projetos no âmbito de um laboratório universitário com a finalidade de permitir o trabalho em paralelo de grupos multidisciplinares e o acúmulo de conhecimento; 
b) Estabelecer, a partir dos princípios analisados na seção anterior, os requisitos de tecnologia e ferramentas de desenvolvimento para a arquitetura de controle de um AUV.

O objetivo específico é propor uma arquitetura de controle de baixo custo para um AUV ao cenário de desenvolvimento de um laboratório universitário nacional caracterizado anteriormente. A metodologia de trabalho deve ser sumária, visando à obtenção de um AUV operacional em curto espaço de tempo. São consideradas apenas as implementações necessárias à execução de manobras pré-programadas pelo AUV. Todavia, as estruturas de software e hardware devem ser compatíveis com a incorporação de outras funcionalidades, expansões e adoção de redundâncias.

\subsection{Estrutura da dissertação}

No capítulo 2 é apresentada a revisão bibliográfica feita para este trabalho.

No capítulo 3 apresenta-se a engenharia de sistemas e seus tópicos que foram julgados pertinentes para esse trabalho.

No capítulo 4 a arquitetura proposta é apresentada em termos gerais, de hardware e de software. Neste mesmo capítulo é feita uma breve comparação com outras arquiteturas.

No capítulo 5, os resultados de desempenho da arquitetura e de continuidade do trabalho são apresentados. Segue-se uma apresentação das conclusões no capítulo 6. 


\section{REVISÃO BIBLIOGRÁFICA DO ESTADO DA ARTE}

Este capítulo apresenta a pesquisa, especialmente voltada para AUVs, feita sobre arquitetura de controle de veículos submarinos não tripulados. O período estudado foi de 1994 a 2010, que abrange a maioria dos trabalhos de arquitetura de controle de AUVs no âmbito acadêmico.

Devido à complexidade da implementação dos veículos submarinos e suas especificidades, optou-se por estudar apenas as arquiteturas de controle aplicadas nesse campo, e não outras arquiteturas empregadas também em outros tipos de robôs. Citam-se as principais famílias de arquiteturas e dois exemplos interessantes, com objetivos similares ao deste trabalho. Por fim, este capítulo apresenta uma avaliação geral do estado da arte, bem como uma análise das tecnologias que surgiram ou desapareceram no período, o que permite ter uma ideia das tendências correntes.

\subsection{Arquiteturas de controle de robôs Móveis - Aplicações em AUVs}

Existem vários termos que devem ser conhecidos para que se possa compreender a linguagem usada pelos autores da área. A arquitetura de hardware pode ser centralizada, descentralizada ou mista [3]. Por centralizada entende-se que um único computador gerencia todo o AUV. Tem a vantagem de facilitar o desenvolvimento e de ser a arquitetura mais simples, porém não é flexível, ficando limitada à capacidade do computador usado, seja em termos de processamento, seja em termos de entradas e saídas.

Uma arquitetura de hardware descentralizada emprega vários processadores comunicando-se entre si por meio de uma rede de dados. Esta arquitetura tem a vantagem de ser flexível e permitir expansões virtualmente ilimitadas. A desvantagem é o aumento da complexidade trazida com a rede de dados e consequentes problemas de comunicação.

Uma solução de compromisso é a arquitetura mista, onde são empregados pequenos processadores para resolver problemas simples, tais como controlar sensores e atuadores, amostrar sinais e prover segurança. $O$ processamento mais pesado é feito em um processador mais poderoso, que se comunica com os outros por meio de um protocolo simples, como RS232, por exemplo.

Em termos de arquitetura de controle, existem vários tipos na literatura [3]: 
Hierárquica - existem vários níveis de hierarquia, as decisões são tomadas no nível superior e os níveis inferiores tratam apenas de processamento de sinais recebidos de sensores e o comando dos atuadores. Os níveis inferiores não possuem iniciativa, o que significa que cada mudança no ambiente deverá ser percebida pelos componentes de nível inferior, a informação será transmitida para os componentes de nível superior, onde será analisada e uma decisão será tomada. O componente de nível superior distribui ordens aos componentes de nível inferior de modo a executar as ações previstas. A vantagem desta arquitetura é a simplicidade conceitual e a separação em diversos níveis. As desvantagens são o elevado tempo de resposta (baixa reatividade) e a grande complexidade do componente de nível superior, dependendo da missão. Fazer modificações nesta arquitetura também pode ser bastante custoso, pois, uma vez que todos os níveis de decisão são rigidamente acoplados, uma modificação pode gerar consequências em todos os níveis.

Heterárquica - existe apenas um nível hierárquico, onde todos os processos tem a mesma prioridade e ocorrem em paralelo. Tem as vantagens de ser mais simples do que a arquitetura hierárquica, melhor resposta temporal, porém surgem problemas de coordenação. Para algumas aplicações onde os diferentes processos podem ocorrer de maneira independente, esta pode ser uma boa opção.

Comportamental - inspirada na biologia, parte do pressuposto de que um conjunto de comportamentos simples, ativados quando ocorre uma alteração no ambiente; por exemplo, ao detectar um obstáculo, contorná-lo, pode resolver problemas muito complexos, à similaridade do que ocorre com insetos. Permite uma organização, pois cada comportamento pode ser uma tarefa diferente, mantém as tomadas de decisão bastante simples e uma resposta temporal razoável, uma vez que, quando um comportamento não está ativo, ele apenas monitora se as condições para sua ativação estão sendo satisfeitas ou não.

Híbrida - Busca-se uma solução de compromisso misturando elementos de qualquer uma das arquiteturas anteriores para chegar a uma solução razoável em função do problema a ser resolvido.

A Tabela 1 apresenta os AUVs estudados no presente trabalho. Apresenta-se nesta tabela informações sobre a arquitetura de controle $\mathrm{e}$ as tecnologias empregadas. Tais informações servirão de base para o estudo a ser apresentado a seguir. 
Tabela 1 - Revisão bibliográfica dos AUVs atuais

\begin{tabular}{|c|c|c|c|c|c|}
\hline Ano & $\begin{array}{l}\text { Arquitetura de } \\
\text { hardware / controle }\end{array}$ & Processador & $\begin{array}{l}\text { Sistema } \\
\text { Operacional }\end{array}$ & Rede & Ref. \\
\hline 1994 & $\begin{array}{l}\text { centralizada / não } \\
\text { menciona }\end{array}$ & $\begin{array}{l}\text { Neuron Chip Set } \\
350 \mathrm{MHz} 68030\end{array}$ & VxWorks & LONTalk & [2] \\
\hline 1997 & $\begin{array}{l}\text { mista / híbrida } \\
\text { (hierárquica/heterárqui } \\
\text { ca) }\end{array}$ & SBC & QNX & STD 32 & [3] \\
\hline 1998 & $\begin{array}{l}\text { descentralizada } \\
\text { hierárquica }\end{array}$ & MC68020+FPU & OS/9 & $\begin{array}{l}\text { Ethernet/ } \\
\text { RS232 }\end{array}$ & [4] \\
\hline 1999 & $\begin{array}{l}\text { descentralizada / não } \\
\text { menciona }\end{array}$ & não menciona & não menciona & CAN & [5] \\
\hline 2000 & $\begin{array}{l}\text { descentralizada } \\
\text { híbrida }\end{array}$ & não menciona & VxWorks & $\begin{array}{l}\text { não } \\
\text { menciona }\end{array}$ & [6] \\
\hline 2000 & $\begin{array}{l}\text { descentralizada / não } \\
\text { menciona }\end{array}$ & $\begin{array}{l}\text { pentium-based } \\
\text { embedded } \\
\text { PC104 }\end{array}$ & não menciona & CAN & [7] \\
\hline 2001 & $\begin{array}{l}\text { descentralizada } \\
\text { hierárquica }\end{array}$ & PC104 & $\begin{array}{l}\text { Solaris/Hugin } \\
\text { OS }\end{array}$ & Ethernet & [8] \\
\hline 2001 & $\begin{array}{l}\text { descentralizada } \\
\text { hierárquica }\end{array}$ & PC104 & QNX & $\begin{array}{l}\text { LonTalk, } \\
10 \mathrm{Mbit} / \mathrm{s} \\
\text { Ethernet }\end{array}$ & [9] \\
\hline 2001 & $\begin{array}{l}\text { descentralizada / não } \\
\text { menciona }\end{array}$ & $\begin{array}{l}166-\mathrm{MHz} \\
\text { Pentium }\end{array}$ & QNX & Ethernet & [10] \\
\hline 2002 & $\begin{array}{l}\text { centralizada / híbrida } \\
\text { (hierárquica/heterárqui } \\
\text { ca) }\end{array}$ & $x 486$ & VxWorks & Ethernet & [11] \\
\hline 2002 & $\begin{array}{l}\text { centralizada } \\
\text { hierárquica }\end{array}$ & PC104 & não menciona & $\begin{array}{l}\text { Ethernet/ } \\
\text { CANBus }\end{array}$ & [12] \\
\hline 2003 & $\begin{array}{l}\text { descentralizada / não } \\
\text { menciona }\end{array}$ & PC104 & Linux & Ethernet & [13] \\
\hline 2003 & $\begin{array}{l}\text { centralizada / não } \\
\text { menciona }\end{array}$ & $\begin{array}{ll}50 & \mathrm{MHz} \\
\mathrm{MC680060} & \end{array}$ & VxWorks & $\begin{array}{l}\text { não } \\
\text { menciona }\end{array}$ & [14] \\
\hline 2004 & $\begin{array}{l}\text { descentralizada ' } \\
\text { hierárquica modificada }\end{array}$ & $\begin{array}{l}\text { Pentium-based } \\
\text { PC-104/uP }\end{array}$ & VxWorks & $\begin{array}{l}\text { Ethernet } \\
\text { e VME- } \\
\text { bus }\end{array}$ & [15] \\
\hline 2005 & $\begin{array}{l}\text { descentralizada } \\
\text { híbrida }\end{array}$ & não menciona & não menciona & Ethernet & [16] \\
\hline 2005 & $\begin{array}{l}\text { descentralizada / não } \\
\text { menciona }\end{array}$ & $\begin{array}{l}\text { Power } \\
233 \mathrm{MHz}\end{array}$ & Tornado II & & [17] \\
\hline 2005 & $\begin{array}{l}\text { descentralizada / não } \\
\text { menciona }\end{array}$ & não menciona & não menciona & $\begin{array}{l}\text { I2C, } \\
\text { Ethernet }\end{array}$ & [18] \\
\hline 2006 & $\begin{array}{l}\text { não menciona / híbrida } \\
\text { (hierárquica/heterárqui } \\
\text { ca) }\end{array}$ & não menciona & não menciona & $\begin{array}{l}\text { não } \\
\text { menciona }\end{array}$ & [19] \\
\hline 2006 & $\begin{array}{l}\text { descentralizada } \\
\text { comportamental }\end{array}$ & PC104 & não menciona & $\begin{array}{l}\text { não } \\
\text { menciona }\end{array}$ & [20] \\
\hline 2006 & $\begin{array}{l}\text { descentralizada } \\
\text { hierárquica }\end{array}$ & não menciona & não menciona & Ethernet & [21] \\
\hline
\end{tabular}




\begin{tabular}{|c|c|c|c|c|c|}
\hline Ano & $\begin{array}{l}\text { Arquitetura de } \\
\text { hardware / controle }\end{array}$ & Processador & $\begin{array}{l}\text { Sistema } \\
\text { Operacional }\end{array}$ & Rede & Ref. \\
\hline 2006 & $\begin{array}{l}\text { centralizada / não } \\
\text { menciona }\end{array}$ & $\begin{array}{l}\text { (Advantech } \\
\text { PCM3350) }\end{array}$ & RT-Linux & $\begin{array}{l}\text { I2C e } \\
\text { ethernet }\end{array}$ & [22] \\
\hline 2006 & $\begin{array}{l}\text { descentralizada / não } \\
\text { menciona }\end{array}$ & não menciona & não menciona & CAN & [23] \\
\hline 2006 & $\begin{array}{l}\text { centralizada / não } \\
\text { menciona }\end{array}$ & $\mathrm{X} 86$ & Windows XP & Ethernet & [24] \\
\hline 2006 & $\begin{array}{l}\text { centralizada / não } \\
\text { menciona }\end{array}$ & Intel ULV Celeron & Windows 98 & $\begin{array}{l}\text { não } \\
\text { menciona }\end{array}$ & [25] \\
\hline 2007 & $\begin{array}{l}\text { descentralizada / } \\
\text { híbrida } \\
\text { (hierárquica/heterárqui } \\
\text { ca) }\end{array}$ & $\begin{array}{ll}\text { AMD } & \text { Geode } \\
300 \mathrm{MHz} & \end{array}$ & Linux & $\begin{array}{l}\text { Ethernet } \\
\text { NTP }\end{array}$ & [26] \\
\hline 2007 & $\begin{array}{l}\text { centralizada } \\
\text { hierárquica }\end{array}$ & 886 & QNX & Ethernet & [27] \\
\hline 2007 & $\begin{array}{l}\text { descentralizada / não } \\
\text { menciona }\end{array}$ & $\begin{array}{ll}\text { AMD } & \text { Geode } \\
300 \mathrm{MHz} & \end{array}$ & Linux & $\begin{array}{l}\text { Ethernet } \\
\text { NTP }\end{array}$ & [28] \\
\hline 2007 & $\begin{array}{l}\text { não menciona / } \\
\text { heterárquica } \\
\text { modificada }\end{array}$ & não menciona & Linux & $\begin{array}{l}\text { não } \\
\text { menciona }\end{array}$ & [29] \\
\hline 2007 & $\begin{array}{l}\text { centralizada / não } \\
\text { menciona }\end{array}$ & intel X86 & Linux & I2C & [30] \\
\hline 2007 & $\begin{array}{l}\text { centralizada / não } \\
\text { menciona }\end{array}$ & Compact $\mathrm{PCl}$ & não menciona & Ethernet & [31] \\
\hline 2008 & $\begin{array}{l}\text { descentralizada / não } \\
\text { menciona }\end{array}$ & $\begin{array}{l}\text { STR9 ARM/PC- } \\
104\end{array}$ & Linux & Ethernet & [32] \\
\hline 2008 & $\begin{array}{l}\text { descentralizada } \\
\text { hierárquica }\end{array}$ & PC104 & Linux & Ethernet & [33] \\
\hline 2008 & $\begin{array}{l}\text { descentralizada } \\
\text { deliberativa (híbrida) }\end{array}$ & $\begin{array}{l}244 \mathrm{MHz} \mathrm{PC} / 104 \\
/ 367 \mathrm{MHz} \text { EPIC } \\
\text { EPX-GX500 AMD } \\
\text { Geode }\end{array}$ & QNX & Ethernet & [34] \\
\hline 2008 & $\begin{array}{l}\text { não menciona / } \\
\text { hierárquica modificada }\end{array}$ & não menciona & não menciona & $\begin{array}{l}\text { não } \\
\text { menciona }\end{array}$ & [35] \\
\hline 2008 & $\begin{array}{l}\text { centralizada / não } \\
\text { menciona }\end{array}$ & $\begin{array}{l}\text { x86-compatible } \\
64 \text { bit } 300 \mathrm{MHz}\end{array}$ & $\begin{array}{l}\mu \mathrm{C} / \mathrm{OS} \\
\text { certified) }\end{array}$ & CAN & [36] \\
\hline 2009 & $\begin{array}{l}\text { centralizada } \\
\text { hierárquica }\end{array}$ & $\begin{array}{l}\text { CMX147786CX } \\
650 \mathrm{MHz} \text { (RTD) }\end{array}$ & VxWorks & $\begin{array}{l}\text { Ethernet/ } \\
\text { RS232 }\end{array}$ & [37] \\
\hline 2009 & $\begin{array}{l}\text { descentralizada / } \\
\text { híbrida } \\
\text { (hierárquica/heterárqui } \\
\text { ca) }\end{array}$ & não menciona & não menciona & $\begin{array}{l}\text { não } \\
\text { menciona }\end{array}$ & [38] \\
\hline 2009 & $\begin{array}{l}\text { descentralizada } \\
\text { hierárquica }\end{array}$ & x86 e ARM9 & Linux & RS232 & [39] \\
\hline 2009 & $\begin{array}{l}\text { descentralizada } \\
\text { híbrida }\end{array}$ & PC104 & Linux & RS232 & [40] \\
\hline 2010 & $\begin{array}{l}\text { descentralizada } \\
\text { híbrida }\end{array}$ & $x 86$ & Linux & Ethernet & [41] \\
\hline
\end{tabular}


Dos 40 artigos pesquisados, nota-se uma tendência forte para as arquiteturas descentralizadas (23 ocorrências, contra 11 centralizadas e 1 mista). Quanto à arquitetura de controle, existe indefinição entre arquiteturas mistas (10) e arquiteturas hierárquicas (11 autores). São raras as arquiteturas heterárquicas.

Quanto às tecnologias, foram avaliados também os tipos de computadores empregados, os sistemas operacionais e os tipos de rede de dados. Quanto aos processadores empregados, a maioria utilizou x86 e placas do padrão PC-104. Supõe-se que isso se deve ao pequeno volume e possibilidade de expansão deste padrão. Alguns usam também processadores ARM9, que são bem mais econômicos em termos de consumo energético e aquecimento. Um autor reporta problemas de aquecimento dentro do veículo devido ao PC-104 [33].

O sistema operacional mais usado foi o Linux e suas variantes, tais como 0 RT-Linux (11 autores). Nota-se também o emprego do VxWorks (6 autores) e QNX (5 autores). Chamou a atenção o uso do $\mu \mathrm{C} / \mathrm{OS}$, que é um sistema operacional criado em $\mathrm{C}$ e que pode ser empregado em microprocessadores, além de ter uso gratuito para pesquisa e código fonte aberto.

A rede de dados mais empregada é sem dúvida o padrão Ethernet (21 autores). Outros protocolos também são comuns, tais como RS232 (4 autores), CAN (5 autores) e I2C (3 autores). Entretanto, alguns autores reportam problemas com cabeamento muito volumoso do padrão Ethernet, principalmente quando o número de sensores e atuadores aumenta [19]. Um autor vai mais longe e compara vários tipos de rede de dados em termos de volume, cabeamento e taxa de transmissão de dados, e conclui que a melhor opção seria o uso de uma rede CAN [12]. Existem autores que propõem CAN como uma solução interessante para um AUV devido à sua simplicidade, confiabilidade, baixo consumo energético e pequena quantidade de cabos [5][23][36].

Para funções de alto nível, existe também o Robot Operational System (ROS) [51], que apesar do nome, não é um sistema operacional, mas uma biblioteca de funções de interesse da robótica móvel que pressupõe que os problemas de baixo nível já tenham sido resolvidos. O ROS estabelece uma camada de comunicação estruturada em cima de um sistema operacional, permitindo que diversos processos estabeleçam uma comunicação ponto a ponto entre si. 
O ROS é uma solução para problemas diferentes daqueles resolvidos pelo presente trabalho. No entanto, ele segue a mesma filosofia e tem objetivos similares, que é permitir o trabalho em paralelo de várias equipes, prover expansibilidade e reuso de componentes já desenvolvidos, com a vantagem de não ficar dependente de softwares proprietários. Assim, o ROS é uma opção a ser estudadas para trabalhos futuros, quando funções de alto nível estiverem sendo desenvolvidas.

\subsection{Evolução tecnológica durante o período de estudo}

Em virtude de o período de estudo abranger duas décadas, é interessante avaliar os desenvolvimentos tecnológicos nesse período para identificar tendências, tecnologias emergentes e fornecer as bases para a tomada de decisões.

A referência [3] apresenta uma visão geral das tecnologias em uso no período de 1984 a 1995, citando 25 diferentes arquiteturas. Nesta época predominavam os processadores da série 68000 da Motorola, abrangendo 16 das 25 arquiteturas. Os processadores da série x86 eram uma minoria, com apenas 3 arquiteturas. Nota-se um gradual abandono dos processadores da série 68000 em favor da família x86 no final da década de 90 e início dos anos 2000, sendo o último caso em 2003 [14].

A Tabela 2mostra as principais tecnologias empregadas nos trabalhos vistos e sua data de lançamento, bem como o período no qual elas foram empregadas.

Tabela 2 - Evolução tecnológica no período em estudo

\begin{tabular}{llll}
\hline Tecnologia & Lançamento & $\begin{array}{l}\text { Período } \\
\text { Emprego em AUVs }\end{array}$ \\
\hline SPARC (processador) & 1987 & 1988 a 2001 & 3 \\
\hline 68000 (processador) & 1979 & 1983 a 2003 & 16 \\
\hline x86 (processador) & 1985 & 1989 a 2010 & 18 \\
\hline AMD Geode (processador) & 1999 & 2007 a 2008 & 3 \\
\hline ARM9 (processador) & 1997 & 2005 a 2009 & 2 \\
\hline LONTALK (rede de dados) & 1990 & 1993 a 2003 & 3 \\
\hline Ethernet (rede de dados) & 1980 & 1995 a 2010 & 20 \\
\hline CAN (rede de dados) & 1986 & 1995 a 2008 & 3 \\
\hline RS232 (rede de dados) & 1969 & 1993 a 2009 & 4 \\
\hline VxWorks & 1987 & 1987 a 2009 & 10 \\
\hline QNX & 1982 & 1997 a 2008 & 5 \\
\hline Linux & 1991 & 2003 a 2010 & 8 \\
\hline
\end{tabular}

A família x86 começa a ser utilizada em 1989, ganha mais espaço no final da década de 90, e permanece até 2010 como a tecnologia dominante. Especial 
atenção merece a família Geode da AMD, que é logicamente compatível com a família x86 e tem um baixo consumo energético e começa a ser empregado no final da década de 2000 .

Outra família de processadores de baixo consumo que começa a ser empregada no final dos anos 2000 é a família ARM9, que vem ganhando muito espaço no mercado de produtos eletrônicos portáteis.

Quanto aos protocolos de rede, a rede LONTalk foi um pouco usada na década de 1990 e no início dos anos 2000. O padrão Ethernet parece entrar tardiamente no ramo, somente em meados da década de 1990 e depois permanece como o principal protocolo de rede, apesar de alguns inconvenientes.

Como alternativas aparecem a rede CAN e a rede RS232. Tais protocolos, às vezes, não substituem a rede Ethernet, mas servem de complementação [3][37].

Quanto aos sistemas operacionais, aparentemente o VxWorks foi o mais utilizado até meados da década de 2000, quando o Linux começa a aparecer com bastante frequência e se torna o mais utilizado na década de 2000. O QNX tem um papel secundário a partir de 1997 e continua até os dias atuais.

\subsection{Arquiteturas de controle de AUV notáveis}

Foi julgado oportuno analisar mais a fundo duas arquiteturas de controle contemporâneas deste trabalho que possuem objetivos e soluções similares e que possam servir de referência.

Uma arquitetura de controle considerada interessante para esse trabalho foi a arquitetura backseat [41]. Essa arquitetura segrega as funções de controle intrínsecas ao veículo das funções de serviço que interessam ao usuário. As funções de controle do veículo são providas pelo fabricante (como atuação de lemes, controle de profundidade, emersão em emergência) e são implementadas em um processador chamado frontseat. As tarefas a serem implementadas pelo usuário (como levantamento hidrográfico, aquisição de dados para estudo de teorias hidrodinâmicas) são executadas em outro processador chamado backseat, como mostrado na Figura 1. Os dois computadores comunicam-se por meio de um protocolo padrão usando uma rede de dados. Tal disposição visa facilitar a troca de veículo ou reaproveitar um veículo para outro tipo de missão diferente da original, pois é fácil reutilizar drivers de baixo nível do veículo e suas funções de segurança 
que já foram extensivamente testadas, reduzindo o retrabalho e aumentando a confiabilidade do software.

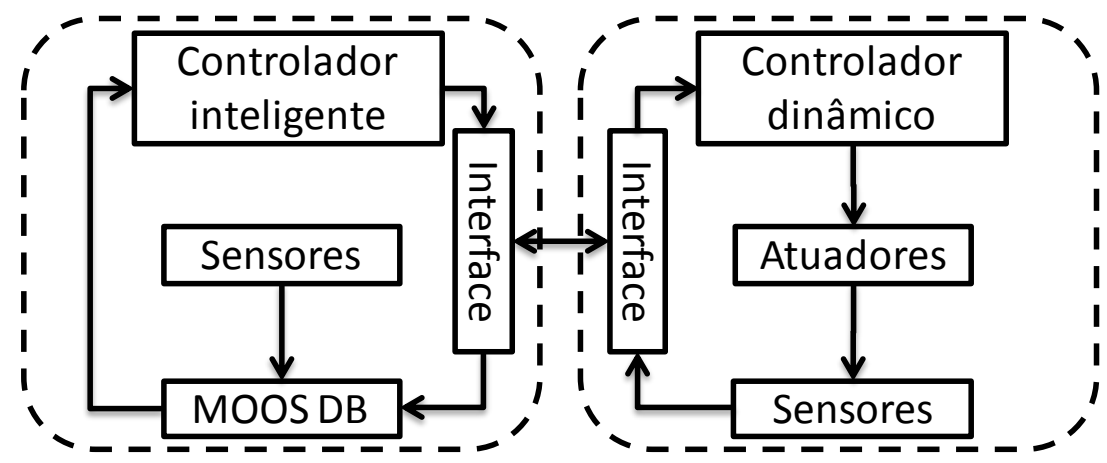

Figura 1 Arquitetura backseat. Traduzido de [41].

Conforme mostrado na Figura 1, Tarefas de alto nível (planejamento da missão, aquisição e processamento de dados) são executadas no computador denominado backseat. Tarefas de baixo nível, como leitura de sensores e controle de profundidade são feitas pelo frontseat. $O$ protocolo de comunicações entre os dois é padronizado, permitindo a troca de qualquer um dos dois.

A arquitetura de controle backseat [41] é um projeto de software de fonte aberta para a comunicação de processos de software em execução nos nós individuais de uma rede de plataformas autônomas. É portátil e independente de plataforma. Contém processos que se comunicam através de um processo chamado de quadro de avisos MOOSDB. É o núcleo da arquitetura e lida com a comunicação entre os processos usando uma arquitetura publicar e inscrever. Assim, todos os processos podem publicar variáveis compostas de pares nome / valor. Quando uma variável for alterada, todos os processos que pediram inscrição para essa variável receberão uma notificação, e eles podem solicitar o novo valor da variável. Os processos incluem todas as funções de controle necessários, bem como de detecção e de processamento. Assegura-se que cada processo possa ocorrer em freqüência especificada e trata de novas mensagens a cada iteração em uma maneira publicar e inscrever.

Esta arquitetura tem o mérito de possuir uma boa estrutura de software, modularidade e facilidade de reutilização. A modularidade também melhora a segurança, ainda que se torne dependente de fornecedores de AUVs que estejam dispostos a se adequar ao protocolo adotado. Por outro lado, uma única falha no equipamento ou software do processo pode causar a perda da missão porque o 
processo é executado em um único computador e todas as outras aplicações dependem do mesmo. A base de dados central também é um gargalo para obter informações. Esta arquitetura é baseada em um protocolo TCP-IP que, por sua vez, requer um sistema operacional e um hardware compatível. Uma vez que utiliza um protocolo definido para comunicação entre 0 frontseat e 0 backseat, torna-se obrigatório empregar AUVs que já se encontram em conformidade com este protocolo, dependendo da disponibilidade de AUVs compatíveis no mercado.

Outra arquitetura muito inspiradora é a DSAAV (Distributed Software Architecture for Autonomous Vehicules) [33]. Esta arquitetura assume uma abordagem mecânica modular para o AUV. Isto significa que cada módulo AUV (exemplos: módulo de bateria, módulo do sensor, o módulo de propulsão) tem interfaces padronizadas, tanto em termos de hardware como de software. A arquitetura de software é desenvolvida através de pacotes de Ethernet UDP, tornando o software muito leve e isso permite empregar microcontroladores sem um stack TCP-IP ou sistema operacional. A comunicação tem uma arquitetura ponto a ponto. A arquitetura de software é composta por 4 camadas. Uma representação gráfica dessa arquitetura é a Figura 2.

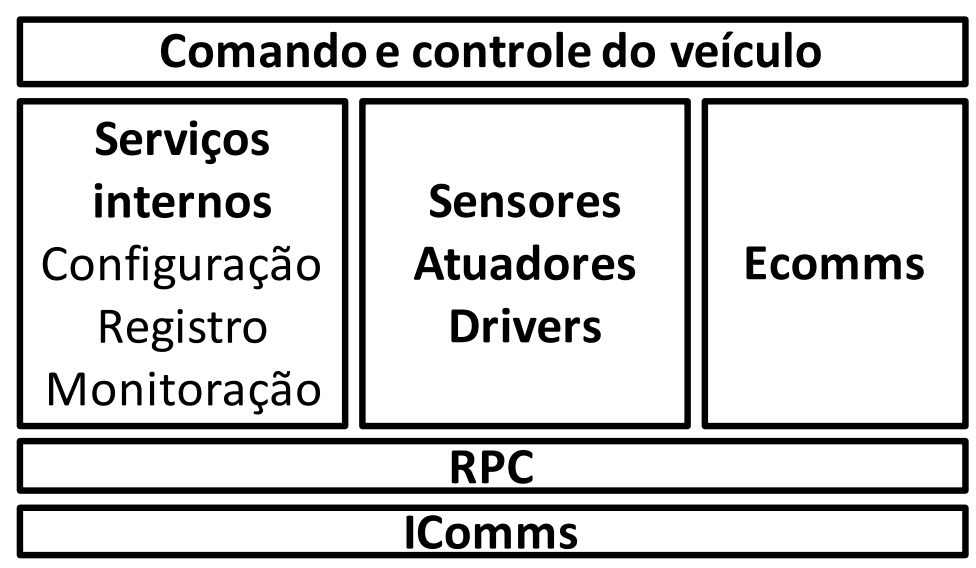

Figura 2 Arquitetura de software DSAAV. Traduzida de [33].

A camada na parte inferior (IComms) fornece uma aplicação de serviço de mensagens pouco confiável sobre a espinha dorsal de comunicação disponível, que pode ser qualquer protocolo, mas no exemplo, é o UDP Ethernet / IP. A próxima camada implementa uma semântica de chamada de procedimento remoto, que fornece confiabilidade para a comunicação e permite a identificação on-line de serviços disponíveis. A terceira camada é composta dos serviços, como serviços 
essenciais (configuração, registro e armazenamento de dados, monitoração do estado dos módulos), drivers de hardware para todos os sensores e atuadores e interface de comunicação externa para os outros veículos e centro de controle. A camada superior abriga os componentes de comando e controle que utilizam os serviços da camada inferior para alcançar as missões do veículo.

Os principais benefícios desta arquitetura são:

- Arquitetura distribuída com suporte para modularidade de hardware e software;

- Robustez e distribuição de carga de processamento através de comunicação ponto a ponto;

- Independência da tecnologia de rede de comunicação;

- Protocolo leve adequado para microcontroladores de baixa potência, o que reduz as necessidades de energia e melhora a confiabilidade, já que estes microcontroladores trabalham em uma temperatura mais baixa;

- A distribuição de componentes em vários nós é quase transparente para os desenvolvedores de software;

- Flexibilidade e extensibilidade;

- Possibilidade de reprogramação dos nós através de Ethernet usando um serviço em conformidade com a arquitetura, o que significa que não há necessidade de acesso físico para atualizar o firmware.

Uma desvantagem para esta arquitetura é a falta de segregação entre as funções de segurança e as demais funções. Isto significa um erro no software pode comprometer todo o AUV, o que, por sua vez, impõe um elevado nível de qualidade a todo o software, a fim de evitar perigo para o veículo, retardando o tempo de desenvolvimento.

\subsection{Avaliação do Estado da Arte}

Basicamente, pode-se afirmar que, no estado atual da arte, os autores que trabalham com AUVs tem mostrado uma preferência por arquiteturas de hardware descentralizado com arquiteturas de controle hierárquicas ou mistas. 
Computadores de grande poder de processamento são a escolha mais comum, mas causam problemas de perda de autonomia devido ao consumo e podem contribuir também para o aquecimento dentro do vaso de pressão do veículo. Uma solução bem comum é o uso de processadores da família ARM, que têm poder de processamento bastante razoável (cerca de 50 MIPS para ARM7 e cerca de 250 MIPS para ARM9 e ARM11, contra cerca de 3000 MIPS de um x86 Pentium IV) e pouco consumo e dissipação térmica (cerca de 0,4 W para um ARM7 e cerca de 30 $\mathrm{W}$ para um x86). Considerando um AUV com um consumo global de $200 \mathrm{~W}$, pode-se dizer que a adoção de processadores ARM tem um impacto significativo na autonomia.

O tipo de rede de dados mais usado é o padrão Ethernet, apesar de problemas de aumento de cabeamento e consumo energético. A rede CAN surge como uma alternativa bastante interessante, dadas as suas características de taxa de transmissão, confiabilidade da transmissão, baixo custo, baixo consumo energético, prioridade com arbitração não destrutiva - assegurando a possibilidade de tempo real - e pouco cabeamento.

Quanto ao sistema operacional, o uso de sistemas de tempo real não é necessariamente a tendência dominante. Vários autores empregam Linux e alguns empregam Windows. Por outro lado, aparentemente o emprego de sistema operacional é uma necessidade, haja vista que não foram encontrados veículos desenvolvidos somente com microprocessadores sem sistema operacional. Uma razão plausível é que o sistema operacional proporciona uma infraestrutura bastante interessante ao desenvolvimento. Um caso bastante interessante foi o emprego do $\mu \mathrm{C} / \mathrm{OS}$ que é aberto e gratuito para universidades e é portável para microprocessadores, além de ser desenvolvido em linguagem $C$ que é acessível para alunos de graduação, o proporciona também uma melhor aprendizagem acerca do que é e como funciona um sistema operacional.

Vários autores demonstraram preocupação de empregar uma arquitetura modular, seja em termos mecânicos, elétricos ou de software, para facilitar o reuso e a adaptação de um veículo já existente a um novo emprego [1][5][9][11][12][19][27] [32][33][40][41], além da questão da redução de custos. 


\section{ASPECTOS DA ENGENHARIA DE SISTEMAS APLICÁVEIS AO DESENVOLVIMENTO DE UMA ARQUITETURA DE CONTROLE PARA UM AUV}

Este capítulo apresenta a engenharia de sistemas e seus tópicos que são interessantes para o desenvolvimento de um AUV em um contexto institucional, ou seja, que incorporará contribuições de diversos atores distribuídos no tempo e no espaço.

Evidentemente, a engenharia de sistemas é um campo muito vasto e aborda muitos problemas não aplicáveis ao desenvolvimento de AUVs. Dentre os conceitos da engenharia de sistemas, foram escolhidos a modularidade, a separação formal entre soluções tecnológicas e necessidades, a classificação funcional, o gerenciamento de interfaces, métodos de desenvolvimento, referencial normativo técnico, plano tecnológico, integração, verificação e validação, e por fim, gerenciamento de configurações.

Tais conceitos foram considerados úteis a esse trabalho em uma análise subjetiva e superficial, não havendo a ambição de fazer uma análise exaustiva de tudo o que a engenharia de sistemas pode oferecer.

\subsection{Introdução à engenharia de sistemas}

Engenharia de sistemas é um campo interdisciplinar da engenharia com foco na maneira de gerenciar e projetar sistemas complexos ao longo de todo o seu ciclo de vida [45]. Questões como logística, coordenação de diferentes equipes e automação se tornam exponencialmente mais difíceis com 0 aumento da complexidade. A engenharia de sistemas lida então com métodos de trabalho e ferramentas para gerenciar riscos e envolve disciplinas tanto técnicas quanto centradas no ser humano, como engenharia de controle, engenharia industrial, estudo de organizações e gerenciamento de projeto.

O termo engenharia de sistemas pode ser encontrado já na década de 1940, nos laboratórios Bell Telephone [42]. A necessidade de identificar e gerenciar as propriedades de um sistema como um todo, o que em projetos complexos pode apresentar uma grande diferença com relação à soma das partes, motivaram o departamento de defesa dos Estados Unidos e a NASA a empregar a engenharia de sistemas [44]. 
A engenharia de sistemas prega 0 uso de ferramentas e métodos para compreender e gerenciar a complexidade de sistemas, tais como modelagem, simulação, arquitetura de sistemas, otimização, dinâmica de sistemas, análise de sistemas, análise estatística, análise de confiabilidade e tomada de decisão.

\subsection{Modularidade}

Para dominar a complexidade e dividir as tarefas para cada pessoa ou equipe, o sistema global precisa ser dividido em partes menores, denominadas subsistemas [43][44][45]. Assim, é possível desenvolver em paralelo as diversas partes e chegar à conclusão do projeto dentro de um prazo menor do que se houvesse um desenvolvimento em série. Além disso, é possível agrupar famílias de competências dentro de cada subsistema, reduzindo a necessidade de um elevado número de competências diferentes dentro de cada módulo, o que reduz a quantidade de pessoal necessária para levar a cabo o projeto.

O grande problema da modularidade é a questão da posterior integração. A comunicação entre diversas equipes, cada uma com um área de conhecimento diferente, é algo bastante complicado. Além disso, a divisão de responsabilidades é algo que costuma trazer muitos desentendimentos se não for tratada de modo claro, objetivo e logo no início do projeto. De qualquer modo, sempre que houver uma interface entre dois subsistemas desenvolvidos por pessoas diferentes, haverá necessidade de uma atividade de integração dos dois subsistemas, e de verificação e validação dos dois sistemas integrados, além das atividades de integração, verificação e validação de cada subsistema isoladamente [45].

Assim sendo, cada interface deve ser bem definida nos estágios iniciais do projeto, de modo que cada pessoa possa desenvolver seu sistema de acordo com as especificações globais e as restrições impostas pelas interfaces. Além disso, toda interface implica em um engessamento do projeto, pois se um módulo precisar mudar a interface, haverá impactos no projeto de outros subsistemas, gerando atrasos e retrabalho. Isso significa que a definição correta das interfaces é algo crítico para um projeto.

A outra decorrência da modularidade é a evidente necessidade da redução de interfaces, seja em número, seja em complexidade, pois cada interface implica em trabalho adicional de coordenação, atividades de integração, verificação e validação, riscos para o projeto, aumento de tempo de desenvolvimento e de custos. 
Consequentemente, o responsável ou coordenador do sistema será forçado a buscar uma arquitetura que facilite o desenvolvimento do produto, reduzindo o número de competências diferentes, reduzindo a interação entre pessoas, especialmente de competências diferentes, e que permita uma rápida identificação das interfaces. Para que haja uma identificação rápida das interfaces, os subsistemas devem ser bem conhecidos pelo responsável. Caso não sejam, eles devem ser evitados ou tratados de maneira especial para evitar riscos ao projeto.

Então pode-se afirmar que os critérios para dividir um sistema em subsistemas são, em ordem de prioridade:

a. Simplificação de interfaces: isso implica em não cortar malhas de controle ao meio, reduzir o número de interfaces ao máximo e definir de maneira objetiva e quantificada as interfaces.

b. Autonomia sobre a solução técnica: implica que a responsabilidade do desenvolvedor de cada módulo é sobre a função desempenhada pelo mesmo e não sobre as suas especificações. Desta maneira, cada responsável tem a liberdade de escolher a arquitetura mais adequada de acordo com o seu conhecimento, abrindo espaço para a inovação e o progresso.

c. Unicidade da responsabilidade: Cada função pode ter apenas um responsável. Caso haja necessidade de competências além da área do desenvolvedor do módulo, ele deverá contratar serviços de terceiros, mas a integração estará sempre sob sua responsabilidade. É necessário que haja sempre uma relação de subordinação entre as partes envolvidas, de modo a garantir sempre, a cada nível do sistema, que haja uma autoridade com poder decisório e com a responsabilidade de arcar com as consequências destas decisões.

d. Agrupamento de competências: é desejável que cada módulo tenha o menor número de competências possível, facilitando o projeto e requerendo menor número de engenheiros. Assim, é desejável que um módulo tenha apenas componentes mecânicas (estruturas, selos), outro módulo seja apenas elétrico (baterias, cabos, disjuntores), outro seja eletrônico (processadores, placas de aquisição de sinais), e assim por diante. 
Para que os responsáveis dos subsistemas possam trabalhar de maneira efetiva e coordenada, evitando o retrabalho, o coordenador deve prover as seguintes informações [45]:

a. Comportamento do sistema de nível superior: sejam casos de uso ou estados gerais da planta, ou uma lista de transientes, um modelo objetivo do comportamento esperado do sistema deve ser apresentado para todos os responsáveis de subsistema para que os mesmos saibam todas as condições dimensionantes para seu módulo.

b. Propósito de cada subsistema: o responsável geral deve informar o que os subsistemas devem fazer para cada situação prevista na seção acima. Pode haver sistemas que não são empregados em todas as situações.

c. Desempenho de cada subsistema: Cada caso de uso deve ser acompanhado de uma especificação quantitativa de desempenho para cada condição, tal como potência fornecida, vazão, temperatura, velocidade máxima, entre outros.

d. Interfaces de cada subsistema: Deve ser informado a cada responsável as interfaces que o seu subsistema tem com outros sistemas. Exemplos de interface são: peso, volume, consumo elétrico, consumo de fluido refrigerante, conectores elétricos, flanges de tubulações, suportes mecânicos, espaço para manutenção, rede de dados, protocolos de comunicação, entre outros.

Vale lembrar que o projeto de tais subsistemas consiste essencialmente em informação e que pode ser replicada inúmeras vezes a custos muito baixos. O custo da criação do projeto, por sua vez, é muito elevado. Assim sendo, sempre que possível é interessante fazer subsistemas genéricos, de modo que eles possam ser reaplicados a diversos projetos, o que é denominado projeto para reuso. Evidentemente, a criação de subsistemas genéricos tem um custo maior e tais subsistema têm desempenhos inferiores, se comparados a subsistema feitos sob medida para uma aplicação específica.

\subsection{Separação formal entre soluções tecnológicas e necessidades}

Durante o projeto de um produto complexo, o propósito de cada sistema é a informação central passada entre cada nível hierárquico [45]. Procedendo dessa forma, cada nível hierárquico tem autonomia para explorar, até o limite de seu 
conhecimento, as possibilidades tecnológicas do estado da arte, mantendo a inovação e reduzindo custos, pois se torna possível relacionar custos às funções (que são relativamente permanentes), e não mais às soluções tecnológicas (que são transitórias, dada a rápida evolução tecnológica atual).

À medida que o projeto avança, vai sendo desenvolvida uma árvore funcional, pois cada responsável de subsistema vai precisar de uma série de funcionalidades internas dentro de seu sistema para atender aos propósitos gerais fixados pelo responsável imediatamente superior [45]. Cada uma dessas funcionalidades corresponderá a um módulo que terá um responsável pelo seu desenvolvimento.

Depois que as soluções tecnológicas forem todas escolhidas, haverá também uma árvore do produto, pois cada sistema é dividido em subsistemas, que por sua vez também são divididos em subsistemas menores.

Evidentemente, existe uma correlação, idealmente biunívoca, entre a árvore funcional e a árvore do produto. Na prática, entretanto, sabe-se que, em geral, tal relação não é biunívoca, pois cada módulo termina fazendo mais do que uma função. A função, no entanto, não pode ser desempenhada por mais de um módulo, pois isso significaria deixar a responsabilidade de uma função compartilhada por dois responsáveis diferentes, ferindo o princípio da unicidade da responsabilidade.

Durante a vida útil do produto, é importante manter o registro das funções sendo desempenhadas pelos sistemas e subsistemas até o nível de componentes, pois assim será mais fácil lidar com a obsolescência dos componentes, uma vez que é mantida a memória do que cada parte deve fazer. Tal informação também é particularmente útil ao adaptar um produto a uma nova aplicação.

É importante, no entanto, estabelecer diferenças entre requisitos funcionais e requisitos não funcionais. Os requisitos funcionais são o objetivo fim do cliente e abrangem as funcionalidades e desempenho. Requisitos não funcionais, por outro lado, são restrições de fabricação, confiabilidade, segurança, fatores humanos, condições ambientais e interface [45]. Tais requisitos podem gerar subsistemas que se destinam a mitigar desvantagens geradas pela solução adotada, tais como problemas de fabricação, perigos devido a falhas de equipamentos ou baixa confiabilidade.

Evidentemente, se surgir, em um futuro distante, uma solução que permita satisfazer todos os requisitos sem que haja subsistemas dedicados aos requisitos não funcionais, esta solução provavelmente será a melhor opção. Entretanto, se não 
ficar registrado que um determinado subsistema apareceu apenas para corrigir um problema intrínseco de uma solução, o pessoal então encarregado de tomar a decisão não saberá se esse subsistema pode ou não ser eliminado sem riscos para o projeto. Existirá então o risco, em versões futuras do produto, de manter um subsistema dispendioso sem necessidade.

\subsection{Classificação funcional}

Para este trabalho, segurança não está relacionada à integridade do pessoal, mas do veículo submarino, uma vez que o veículo em questão não possui tripulantes. Entende-se que, mesmo o AUV sendo muito mais barato do que os competidores, como navios de superfície, a perda de um AUV implica em custos elevados e atrasos em um projeto, o que não é desejável.

A norma IEC61508 [42] define as diretrizes para o projeto e manutenção de sistemas eletrônicos de segurança. Esta norma estabelece quatro níveis de integridade (sendo 1 o mais baixo e 4 o mais elevado) que podem ser empregados como referência de acordo com a necessidade da redução do risco. Define-se risco um binômio probabilidade / consequência. Um risco pode ser aceitável se ele tiver uma probabilidade muito baixa ou uma consequência insignificante.

Caso exista um risco inaceitável em uma determinada instalação, é necessário adicionar barreira (para mitigar a gravidade da consequência) ou sistemas de segurança (para reduzir a probabilidade de ocorrência). Quanto maior a redução da probabilidade de ocorrência necessária, maior o nível de integridade. Todo tipo de equipamento tem uma taxa de falha associada. Essa taxa de falha geralmente é mais elevada no início da vida útil do equipamento devido a problemas de fabricação. No final da vida útil, essa taxa também tem a tendência de se elevar devido ao desgaste.

No projeto de sistemas que afetam a segurança e que devem ter uma confiabilidade elevada para assegurar a segurança, cuidados especiais com a fabricação e projeto devem ser tomados [42]. Tais cuidados têm um custo elevado e que é proporcional ao nível de segurança. Entretanto, reduzir a taxa de falhas devido ao desgaste pode ser praticamente impossível ou muito caro.

Se for empregada uma arquitetura na qual a função de prover segurança é completamente separada da função normal do equipamento, conforme vista na Figura 3, será possível empregar cuidados especiais de projeto e fabricação somente em uma pequena parte do equipamento, reduzindo o custo e mantendo a 
segurança. Além disso, uma vez que o equipamento que provê a função de segurança não trabalha o tempo todo, são reduzidos os problemas de desgaste.

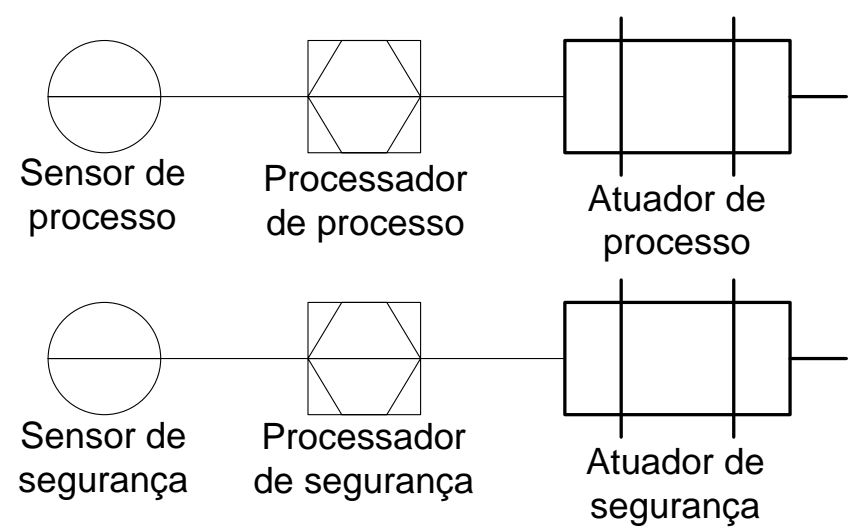

Figura 3 Arquitetura típica de um sistema de controle com requisitos de segurança [42]

Adicionalmente, funções de segurança requerem equipamentos simples, são facilmente identificáveis e não variam muito de geração para geração do sistema. Assim, funções de segurança podem ser reusadas com maior frequência do que as funções normais de controle, que variam bastante de versão para versão. Através do reuso, pode-se reduzir o custo das funções de segurança. Assim ocorre uma economia de esforço muito grande na atualização do sistema de controle normal, que não precisa de um controle de qualidade do nível de sistemas de segurança.

Entretanto, nem sempre é possível separar as funções de segurança das demais funções (exemplo: propulsão). Tais funções, neste trabalho, são denominadas como funções operacionais críticas. Estas são custosas por necessitarem um controle de qualidade rigoroso para todo o sistema associado e devem ser reduzidas ao máximo.

Concluindo, ao se estabelecer níveis diferenciados de funções e critérios objetivos para enquadrar uma determinada função em um determinado nível, mantendo independência e segregação, entre os diversos níveis, torna-se possível atender a critérios elevados de segurança e manter um padrão de qualidade normal para a maior parte dos sistemas [42].

\subsection{Gerenciamento de interfaces [45]}

Uma vez que o projeto progride definindo subsistemas e as interfaces entre os subsistemas, deve-se atentar para o fato de que cada subsistema diz respeito a apenas um responsável e cada interface diz respeito a, no mínimo, dois 
responsáveis. Assim sendo, modificar interfaces é pelo menos duas vezes mais oneroso do que modificar um subsistema. À parte a solução trivial de reduzir o número de interfaces, a solução clássica é manter um controle rígido sobre as interfaces e à clarificação da natureza das mesmas.

Existem muitos tipos de interfaces, tais como:

- Peso (massa e posição do centro de massa);

- Volume (volume total e dimensões);

- Fixação mecânica (calços, jazentes, apoios, prendedores);

- Alimentação elétrica (tipo, tensão, tipo de cabeamento, conectores);

- Dados (protocolo, taxa de transmissão, meio físico);

- Fluidos (flanges, tubulações, tipo de fluido, pressão, temperatura);

- Transferência de calor (dissipação térmica, refrigeração);

- Penetrações estruturais (furos, prensa cabos, janelas de inspeção);

- Interface entre partes de software.

Haja vista a enorme gama de possibilidades que os responsáveis de subsistema têm para o projeto e a dificuldade de modificar as interfaces, é muito útil, logo no início do projeto, estabelecer interfaces padronizadas a serem empregadas por todos. Isso reduz o esforço de projeto, uma vez que o número de desenhos a serem produzidos diminui, facilita a troca entre os componentes e flexibiliza posteriores modificações. A desvantagem é que tal abordagem de projeto requer um responsável geral experiente na área que conheça as necessidades mais gerais e que gaste um tempo vislumbrando um conjunto de soluções integradas que forme um arcabouço intrinsecamente harmonioso, possibilitando solucionar uma grande gama de problemas.

Concluindo, uma vez definidos os subsistemas de um sistema, as interfaces também precisam ser precisamente caracterizadas para possibilitar a posterior integração [45]. Nas fases de projeto de subsistemas e durante a vida útil do sistema, mudanças em interfaces devem ser evitadas tanto quanto possível. Se realmente necessário, a decisão da mudança de interface entre dois subsistemas deve ficar sempre a cargo do responsável do sistema e nunca ser permitido que um desenvolvedor de subsistema mude a interface. Os dados de interface, junto com as informações de funcionalidade que o subsistema deve prover, devem ser mantidos 
durante toda a vida do sistema para permitir novas versões e compensar a obsolescência.

\subsection{Decisão sobre o método de desenvolvimento - reuso / fazer / comprar}

Para obter um sistema qualquer, pode-se lançar mão de três recursos: compra, reuso de outro sistema e fazer o sistema desejado [45]. Cada uma dessas opções tem suas vantagens e desvantagens, analisadas a seguir:

\subsubsection{Comprar}

Existem muitas modalidades de compra:

a) Caixa branca: quando o fornecedor providencia o produto com toda a documentação necessária para que sejam feitas modificações, reparos e inspeções no produto. Incluem-se aí código-fonte de software e suas especificações. É sempre desejável a obtenção de tais informações para evitar uma dependência muito grande de um fornecedor ao longo da vida útil do produto.

b) Caixa preta: quando o fornecedor fornece o produto com uma documentação que permite apenas a manutenção do produto na forma como ele é. Pode ser uma imposição do fornecedor devido a segredos industriais. Isso cria uma relação de dependência e deve ser evitado. Em alguns casos, não é possível evitar, tais como em produtos que requerem alta tecnologia e envolvem segredos estratégicos.

c) Função completa: Um sistema serve para prover uma função. Ao invés de especificar um componente, a organização pode especificar uma função ao fornecedor. Assim sendo o fornecedor irá tomar parte no processo construtivo do sistema global e garantir a satisfação do desempenho da função. Isso reduz o trabalho da equipe de projeto por um lado, mas aumenta o poder do fornecedor junto à organização contratante.

Se essa função for crítica ao sistema, levar muito tempo para ser desenvolvida ou não puder ser efetivada por mais de um fornecedor, devido à necessidade de uma capacitação especial, o fornecedor saberá que tem a capacidade de atrasar o projeto e demandará, ao longo do desenvolvimento, sucessivos aportes de capital. A experiência aponta para um aumento de preço em relação à estimativa inicial. 
A compra é adequada para subsistemas pequenos, de desenvolvimento rápido ou médio e que possam ser feitos por mais de um fornecedor disponível no mercado e é altamente inconveniente se essas três condições não forem atendidas.

Para funções de segurança, que são simples, facilmente identificáveis desde o início do projeto e sofrem poucas mudanças ao longo do projeto, a compra é geralmente uma boa opção. Adicionalmente, do ponto de vista de análise de segurança, é interessante haver total independência entre o executor e o inspetor, bem como um contrato formal entre as partes.

\subsubsection{Reusar}

O conceito de desenvolvimento com reuso tem algumas implicações:

a) os produtos desenvolvidos pela instituição são genéricos, ou seja, são adaptáveis a uma gama de aplicações, o que implica em flexibilidade e margens no dimensionamento. Para que isso seja possível, eles devem ser modulares e ter poucas e bem definidas interfaces. Os produtos mais complexos são construídos a partir de componentes simples;

b) a instituição já possui uma quantidade de produtos;

c) a instituição possui competência para adaptar os produtos a uma nova situação; e

d) o reuso quase nunca é total. Pelo menos uma parte dos produtos reusados precisam sofrer modificações.

Vantagens: diminuição do custo e tempo de desenvolvimento de novos sistemas, emprego de componentes já testados extensivamente em condições de trabalho normais, com modos de falha e confiabilidade possivelmente conhecidos, maior facilidade de efetuar a manutenção (devido à modularidade), diminuindo o custo do produto e a disponibilidade. Além disso, o risco do projeto não se eleva para o caso de um produto já bem testado.

Desvantagens: o projeto de componentes genéricos toma mais tempo e recursos do que o projeto de componentes específicos para uma determinada situação. Se não houver uma expectativa de que, no futuro, haverá uma necessidade similar, desenvolver um componente genérico pode ser ineficiente.

Além disso, nem sempre o responsável do novo sistema aceita o componente já testado, exigindo outro desenvolvimento. Por isso, a instituição deve adotar regras de projeto muito explícitas no sentido de exigir uma justificativa para pedir o desenvolvimento de um novo produto. 
Um produto genérico geralmente não é ótimo para um caso específico. Ele costuma ser razoável para uma gama de aplicações. Se o sistema a ser desenvolvido necessitar de um desempenho muito grande, pode ser que uma boa parte dos componentes tenha que ser específicos.

Conclusão: dificilmente um novo sistema terá apenas componentes reusados. Entretanto, para redução de custos, riscos (de projeto e técnico), consecução de objetivos de confiabilidade, disponibilidade e segurança (funções de segurança), o emprego de reuso será sempre interessante. Para sistemas experimentais com alto desempenho, severas restrições de peso, volume, forma e outras características, e cujos componentes não tem a expectativa de serem reusados, componentes sob encomenda podem ser a melhor solução.

Funções de segurança, depois de verificada a aplicabilidade ao projeto corrente, são frequentemente reusadas, pois elas são relativamente modulares, caras para serem produzidas e mudam pouco dentro de uma família de sistemas. Isso significa que a especificação das funções de segurança deve levar em conta o provável reuso posterior.

\subsubsection{Fazer}

Sistemas que devem ser feitos pela própria organização são aqueles:

a) que são vitais para o sistema, ou seja, podem causar atraso no projeto se não forem feitos;

Se a organização se vir dependente de um determinado colaborador para cumprir o cronograma, o mesmo imporá sucessivos aportes de capital ou fará imposições indesejadas sobre o projeto. Isso ocorre devido ao peso estratégico de seu sistema no desempenho da organização contratante. Por isso, deve-se evitar dependência para que os prazos e os orçamentos sejam cumpridos.

b) para os quais existe falta de capacitação do mercado nacional de fazê-lo;

Sistemas de alta tecnologia muitas vezes não são dominados pelo mercado nacional. A opção de depender de fornecedores estrangeiros costuma ser muito incômoda devido ao elevado preço, taxas de câmbio, 
falta de apoio técnico e problemas logísticos no futuro. Além disso, muitos sistemas não estão à venda e precisam ser feitos no País.

c) que demoram muito tempo para serem produzidos;

Tendo em vista que projeto e construção de meios navais tomam muito tempo, os sistemas que tomam muito tempo para serem construídos tem um impacto grande no cronograma. Se um sistema vital deixa de ser feito, o projeto pode ser atrasado do tempo necessário para a construção desse sistema. Se isso ocorre com vários sistemas, o projeto começa a correr risco. Esse é um aspecto que dá a um fornecedor externo a possibilidade de fazer exigências mais elevadas perto do evento de entrega do sistema e do meio naval. Nesta época, a autoridade se encontra espremida pelos prazos e tenderá a fazer uso de suas últimas reservas para finalizar o projeto. Mas, se vários fornecedores, ao mesmo fizerem elevações nas exigências por pagamento, provavelmente o programa estourará o orçamento;

d) que não podem ser rapidamente definidos pela equipe de projeto devido à falta de informações.

Neste caso, as especificações completas para o sistema só serão obtidas em fases muito avançadas de projeto. Isso significa que haverá várias mudanças na especificação ao longo das fases de projeto. Cada mudança implicará em pagamentos adicionais caso o sistema seja desenvolvido por um fornecedor externo. Além disso, a própria formalidade contratual entre a organização contratante e o fornecedor engessa esse processo e gera atrasos, além de retrabalho e aumento do custo.

Tipicamente, para sistema de controle de um veículo, as funções normais de operação devem ser especificadas e produzidas pela própria organização, pois elas incorrem nos itens a, c e d descritos anteriormente. Por outro lado, funções de segurança tipicamente podem ser terceirizadas nas aplicações navais, pois elas são facilmente identificáveis, sofrem poucas alterações, são relativamente simples e a formalidade contratual é interessante do ponto de vista de análise de segurança, a saber, a independência entre aquele que produz e aquele que verifica [42]. 
Entretanto, para fazer um determinado sistema, as seguintes condições devem ser encontradas:

a) a própria organização possui pessoal com as competências necessárias à produção;

b) os materiais necessários à construção dos sistema estão disponíveis;

c) deve ser possível adquirir (fazer, comprar ou reusar) as ferramentas necessárias;

d) treinamentos adicionais necessários devem ser identificados e previstos no cronograma.

A equipe que produzirá o sistema deve então checar se todas as especificações estão completas e disponíveis, se todas as máquinas e ferramentas necessárias estão prontas, se o pessoal está pronto para produzir, se existe um processo adequado e testado de produção, se os programadores estão prontos (treinados dentro da filosofia a ser implementada - programadores geralmente tem sua própria maneira de trabalhar e nem sempre se adaptam a novas maneiras), se as instalações de teste estão disponíveis e se os casos de teste do software foram adequadamente definidos.

$\mathrm{Na}$ prática, fazer significa integrar vários componentes que possam ser comprados no mercado. Não é possível projetar desde a matéria prima bruta (minério, por exemplo). Mas deve ser tomado cuidado para que os componentes estejam disponíveis quando necessário.

A desvantagem de fazer é a necessidade de um núcleo técnico que domine as competências necessárias à integração. Isso significa adquirir a competência por algum meio (pesquisa e desenvolvimento, transferência de tecnologia) e mantê-la. Para isso, esse núcleo técnico deve ter uma carreira estável para reduzir a rotatividade de pessoal e manter as competências. Adicionalmente, esse pessoal deve ser mantido em trabalhos relacionados a essas competências para manter a qualificação.

Para o caso específico de um laboratório, as competências críticas podem ser mantidas por meio dos professores envolvidos, por meio de técnicos com estabilidade e em menor grau, por meio dos alunos. Manter competências muito específicas usando alunos tem suas complicações, dado que eles permanecem pouco tempo no laboratório. 


\subsection{Escolha de referencial normativo técnico}

Diversos ramos da engenharia desenvolvem normas e padrões para assegurar a qualidade e padronizar o trabalho. Tais padrões de engenharia contém uma vasta experiência acumulada em seu conteúdo, refletindo o emprego de boas práticas já extensivamente testadas no mercado [45].

Sempre que possível e aplicável, é interessante identificar normas e padrões de engenharia ou recomendações que possam agregar valor ao projeto. No caso de um laboratório universitário, existe também a vantagem educacional, que é iniciar os alunos à prática de projeto baseado em normas.

Um aspecto é que o custo financeiro de incorporar tais normas pode ser praticamente nulo, pois elas já existem e podem ter acesso gratuito. A única desvantagem é que os alunos precisam de um tempo a mais para estudar as normas, o que implica um custo em termos de esforço.

\subsection{Plano tecnológico [45]}

Atualmente, existe uma evolução tecnológica muito veloz e existem muitas opções disponíveis no mercado. Ao se adotar uma estrutura hierárquica de projeto, onde os desenvolvedores de subsistemas tem liberdade para encontrar a solução que Ihes parece mais adequada, existe a tendência natural de emprego de muitos tipos de tecnologias diferentes para um mesmo tipo de problema, como por exemplo, conectores e cabos elétricos.

Essa tendência cria problemas logísticos, que é manter um estoque de uma grande variedade de componentes diferentes que, no fim, fazem a mesma coisa e provavelmente não são intercambiáveis.

Além disso, cada tecnologia tem um modo de funcionamento que às vezes requer um tempo considerável de aprendizado. Se dois desenvolvedores usam tecnologias diferentes, por exemplo, linguagem de programação, ambiente de desenvolvimento, microprocessadores, sensores, entre outros, fica muito difícil realocar pessoal de um subsistema para outro, pois será necessário muito tempo de aprendizado.

Existe ainda o problema da obsolescência. Algumas vezes uma tecnologia tem um desempenho muito interessante para uma dada aplicação, porém se ela deixar de ser fabricada, o projeto encontrará contratempos para sanar o problema. 
Se for definido um pequeno conjunto de soluções admissíveis para o projeto logo de início, todos esses problemas podem ser minimizados, reduzindo o custo devido à economia de escala e redução de estoques e os atrasos no projeto devido à diminuição de variáveis imprevisíveis.

Entretanto, não basta que o número de tipos de componentes seja reduzido para que o andamento do projeto esteja assegurado. Os seguintes aspectos devem ser levados em consideração na escolha das tecnologias empregadas:

a. Maturidade [45]: nos dias de hoje existe uma acelerada evolução tecnológica. Novas tecnologias surgem o tempo todo e velhas tecnologias desaparecem. A experiência mostra que muitas tecnologias aparecem, mas poucas se firmam no mercado. As tecnologias que não conseguem uma parcela do mercado tendem a desaparecer muito rapidamente. Por outro lado, tecnologias que já se firmaram como um padrão tendem a persistir em produção por tempos mais longos. Dessa forma, ao começar um projeto, que deve durar vários anos, é interessante buscar tecnologias maduras e amplamente difundidas, mas que ainda não começaram a cair em desuso. Essa abordagem reduz o risco de ter que tratar problemas de obsolescência. Exemplos de tecnologias maduras são o padrão Ethernet e a rede CAN.

b. Conhecimento da tecnologia: bastante relacionado à maturidade, é a facilidade com que se pode obter pessoal com capacidade de lidar com a tecnologia em questão, seja por meio de admissão ou treinamento do pessoal. Tecnologias amplamente conhecidas geralmente dispõem de amplo acesso à documentação na internet, sejam programadores que divulgam seus códigos antigos, sejam universidades ou fabricantes.

c. Desempenho técnico: às vezes é possível achar no mercado novas tecnologias que tenham um desempenho muito elevado. Existe uma natural tendência de orientar a escolha no sentido do melhor desempenho e esquecer outras opções que também atendam os requisitos e que tenham outras vantagens para o projeto no longo prazo. Deve-se combater essa tendência de buscar um ponto de desempenho sacrificando todos os outros fatores e lembrar que, após 
atingir o nível mínimo de desempenho requerido pela aplicação, o excesso de capacidade pode ser inútil.

d. Custo: Ao escolher uma tecnologia é muito importante atentar para o modo de emprego da mesma. Se o ambiente de uso for hostil por diversas razões, tais como manuseio, atmosfera salina, choques, pessoal inexperiente, o emprego de tecnologias dispendiosas poderá acarretar grandes gastos imprevistos. Por outro lado, as consequências da falha desse equipamento devem ser levadas em conta em termos de custo ou atrasos no projeto. Em suma, a probabilidade de danificar o componente durante a operação normal e as consequências para o projeto devem ser pesadas para cada tipo de tecnologia.

e. Disponibilidade no mercado local e tempo de aquisição: um fator que acrescenta muita confiança ao projeto é ter a disponibilidade, no mercado local, dos componentes empregados. Isso permite reduzir estoques e evita atrasos devidos a falha de componentes, que podem ser rapidamente repostos. Depender de um importador sujeita o projeto a muito tipo de imprevisto e adiciona um tempo de aquisição grande a qualquer componente extra. Usar componentes feitos sob encomenda também pode gerar atrasos e gastos adicionais por ficar sujeito à disponibilidade de um fornecedor único.

\subsection{Integração, verificação e validação}

Uma vez adotada a modularidade para permitir reuso e desenvolvimento paralelo de subsistemas, apesar da adoção de padrões de interface, problemas de integração são muito frequentes. Isto se explica pelos contrastes no entendimento das especificações pelos diferentes desenvolvedores responsáveis pelo sistema. Assim sendo, cada subsistema deve ser concebido de maneira a poder ser testado individualmente e depois ser testado de maneira integrada ao sistema de nível superior.

Faz parte das boas práticas de engenharia ter um processo gradual de validação dos sistemas junto ao cliente [45]. Dada a complexidade de uma arquitetura de controle, recursos específicos e atividades devem ser planejadas para levar a cabo esse processo. Tais recursos tem seu custo, mas representam um 
ganho em termos de risco para o projeto e redução de atrasos. Uma vez que o custo de mão de obra é o principal condicionante do custo de desenvolvimento de um sistema de controle, uma redução nos atrasos implica em uma redução no custo total. As ferramentas consideradas necessárias, no caso de um laboratório de uma universidade, são:

- Um espaço para acomodar os simuladores e sistema de controle em desenvolvimento (hardware in the loop);

- Um espaço para acomodar modelos físicos (atuadores e sensores sendo integrados) empregados nas atividades de desenvolvimento e testes;

- Os processadores e placas de entrada e saída a serem utilizadas;

- Software de desenvolvimento de código e programação e hardware para programação e depuração associado;

- Computadores pessoais;

- Redes de dados a serem empregadas no veículo.

De acordo com [42], a perda de um AUV seria classificada como uma consequência menor e bastaria um fator de redução de risco associado ao nível de integridade 1 para tornar esse risco aceitável. Assim sendo, o processo de desenvolvimento de hardware e software deverá seguir a ideia geral de um componente com o nível de integridade 1 . Tal nível de integridade requer controle de qualidade e verificação por outra pessoa, por exemplo, mas não requer nenhum tipo de ferramenta especial ou formação do pessoal envolvido, como é o caso dos níveis de integridade 3 e 4.

Para reduzir o tempo de desenvolvimento e facilitar os testes, faz-se mister desenvolver simuladores estimulados para checar se o software de controle foi corretamente desenvolvido. Tais simuladores podem ou não incluir as características dinâmicas dos equipamentos que eles simulam. A inclusão da dinâmica se faz necessária quando o controle é em tempo contínuo (PID, por exemplo). Se por um lado a inclusão da dinâmica permite inserir melhor o realismo nos testes, ela requer um tempo de desenvolvimento considerável se comparada aos simuladores de interface, que são suficientes para controle de processo a eventos discretos. 
Esses simuladores são desenvolvidos a partir das especificações geradas pelo responsável do sistema de nível superior. Devem ser produzidos em paralelo com o sistema de controle e permitem fazer a verificação do código fonte baseada nas especificações. Simuladores não tem, teoricamente, qualquer possibilidade de identificar erros na especificação.

Após o término da codificação e verificação de cada módulo de software, será necessário integrá-lo ao sistema global, resolvendo os problemas de interface e interação entre cada módulo.

Depois de integrar todos os subsistemas no sistema de controle, inicia-se os testes de desempenho global e compara-se com os requisitos do responsável. Devem ser feitos testes para averiguar cada um dos desempenhos. Ao final, tendo sido resolvidos todos os problemas, o sistema de controle já se encontra pronto para ser instalado no AUV.

Deve-se ter especial atenção à proteção dos equipamentos durante a instalação e manuseio dos equipamentos do veículo e do sistema de controle. É importante lembrar que a operação de um veículo submarino pode ser cansativa e repetitiva, o que aumenta enormemente a possibilidade de erros. Assim sendo precauções devem ser tomadas para evitar conexões em lugares errados - por meio de conectores polarizados e que não encaixam em outro lugar que não o correto, por exemplo - cabos devem ser protegidos contra cortes, superfícies quentes e esforços mecânicos.

\subsection{Gerenciamento de configurações}

Com o avanço do projeto e a existência de versões do sistema global já em operação, é necessário registrar detalhadamente qual a versão de cada módulo para cada sistema, sendo essa informação denominada configuração [45]. Naturalmente, à medida que problemas apareçam, seja por problemas na concepção, seja por adição de novos requisitos, alguns subsistemas sofrem modificações. Após tais modificações, uma nova atividade de integração, verificação e validação deve ser feita para demonstrar o correto funcionamento do conjunto. Finalmente, essa nova configuração tem que ser registrada para permitir o acompanhamento e a manutenção do sistema. 
Sem um gerenciamento de configurações adequado, a manutenção do sistema fica mais difícil por não se saber ao certo qual a versão correta que cada módulo deve ter, o que implica em retrabalho de integração maior após cada modificação [45].

\subsection{Considerações finais sobre a engenharia de sistemas}

Com o surgimento de projetos de elevada complexidade e consequente aumento de diferentes competências necessárias, o trabalho coordenado por vários atores (pessoas e instituições) passou a ser necessário. Para facilitar essa coordenação, adota-se o conceito de sistema, que é uma entidade com interfaces entradas e saídas - bem conhecidas e que tipicamente fica sob a responsabilidade de um único ator. Assim, os projetos de elevada complexidade se tornam até certo ponto modulares para permitir o trabalho em paralelo e aproveitar as competências de cada ator.

Obviamente, o gerenciamento das interfaces se torna uma questão crítica para o sucesso do projeto, pois um mero erro de compreensão sobre uma interface pode tornar o sistema como um todo inviável. Assim, durante todas as fases do projeto e construção, a verificação das interfaces deve ser executada regularmente.

Adicionalmente, atividades de integração, verificação e validação devem ser previstas em todos os níveis de sistemas e subsistemas.

Para explorar ao máximo o conhecimento de cada ator e explorar a evolução tecnológica, não se deve impor a cada ator como projetar o sistema, mas apenas o que o sistema deve fazer (requisitos funcionais) e suas características intrínsecas (requisitos não funcionais, como segurança). Esse conceito chama-se separação formal entre soluções e necessidades.

Outro aspecto muito importante é a classificação funcional, que é separar completamente funções relacionadas à segurança das funções normais. Assim é possível projetar um sistema que atenda aos requisitos de segurança sem impor um controle de qualidade rigoroso para todo o projeto.

Cada ator deve ter em mente quais as vantagens e desvantagens que cada método de desenvolvimento apresenta, a saber: o reuso, a compra e fazer.

Para aproveitar o conhecimento já criado nas normas de engenharia e manter a consistência por todo o projeto, é necessário estabelecer a priori quais as normas a serem aplicadas em todo o projeto. 
Sistemas complexos, devido ao enorme esforço de projeto que eles demandam, tendem a serem usados por muito tempo e possuem várias necessidades similares em vários subsistemas. Assim, para facilitar a logística e reduzir custos, é muito interessante limitar as soluções tecnológicas que possam ser empregadas por cada ator em se tratando de itens simples, como cabos, componentes eletrônicos e tubulações.

Por fim, sistemas complexos sofrem muitas modificações ao longo de sua vida para atender a diferentes requisitos. Assim, gerenciar as configurações para evitar esforços recorrentes de integração, verificação e validação é muito importante.

Observados esses preceitos, espera-se obter resultados razoáveis com um esforço de projeto reduzido no longo prazo, obtendo a continuidade e o acúmulo de conhecimento produzido por cada ator. 


\section{DESENVOLVIMENTO}

Busca-se, neste capítulo, apresentar o laboratório de veículos não tripulados, a versão anterior do sistema de controle do AUV Pirajuba, os requisitos e o desenvolvimento da arquitetura criada para este trabalho.

\subsection{Estudo de caso do Laboratório de Veículos não Tripulados}

O Laboratório de Veículos não Tripulados possui tipicamente alunos de iniciação científica e de pós-graduação. $O$ foco do laboratório é desenvolver robôs submarinos para diversas aplicações, tais como levantamentos hidrográficos, inspeções submarinas, e estudos oceanográficos. Como suporte a essas atividades, são feitos estudos e desenvolvimentos relativos à hidrodinâmica, algoritmos de controle e algoritmos de navegação.

Os alunos de iniciação científica permanecem tipicamente apenas de 1 a 3 anos no laboratório. Alunos de mestrado permanecem no máximo 3 anos e alunos de doutorado ficam de 3 a 4 anos.

Cada aluno tem diferentes tipos de experiência e aspirações. A missão do laboratório é desenvolver novas tecnologias, mas também tem o objetivo de propiciar condições de engrandecimento pessoal e intelectual para os colaboradores. Assim, o tema de cada trabalho deve ser capaz de ser enquadrado na moldura de tempo disponível dos alunos, nos interesses do laboratório e nas aspirações individuais de cada aluno.

Isso implica que quase sempre os alunos trabalham em um assunto que é novo para eles, requerendo aprendizado sobre as tecnologias (sensores, atuadores, computadores, ambientes de desenvolvimento, linguagens de programação) e sobre as dificuldades inerentes dos veículos submarinos, tais como estanqueidade, pesos e centros, integração casco - motor - hélice, manobrabilidade, navegação, etc.

$\mathrm{O}$ orçamento também é limitado. A maior parte do financiamento vem de fundos a prazo perdido que impõem prazos, requerem muitos controles e criam uma carga de trabalho administrativo considerável. O mercado local tem muitas restrições, sendo a grande maioria dos componentes importados. A compra de um item no exterior por meio de uma importadora, além de incorrer em custos elevados, é lenta e tem pouca confiabilidade. Além disso, algumas das tecnologias empregadas pelo laboratório muitas vezes são consideradas críticas para o 
desenvolvimento de armamentos e sofrem restrições de importação, como as unidades de medição inerciais.

As instituições que prestam serviços de apoio aos ensaios tem um comportamento irregular devido à existência de clientes mais importantes, como grandes empresas. Muitas vezes os prazos impostos pelas financiadoras não podem ser cumpridos devido a repetidos adiamentos na execução dos serviços. Mesmo que os alunos do laboratório façam a maior parte do trabalho da instituição, a simples necessidade de empregar as instalações (que ficam quase sempre à disposição das grandes empresas) já torna a execução dos serviços muito difícil.

Existem também empresas ligadas ao ramo de artigos náuticos que agregam bastante ao laboratório, com um know-how de muitos anos e boa disponibilidade. Por outro lado, o custo é elevado.

Os alunos, devido à sua inexperiência, têm a tendência de danificar frequentemente os equipamentos. Essa tendência, acoplada à demora da compra de itens importados e à imposição de prazos por parte das instituições financiadoras, cria complicações ao progresso da pesquisa e desenvolvimento nesse laboratório.

Em suma, o laboratório precisa gerenciar uma alta rotatividade potencial de pessoal, dificuldades na compra de alguns equipamentos e serviços especializados, orçamento limitado, prazos apertados e vários controles administrativos. Neste cenário, deve-se apresentar resultados científicos embasados em desenvolvimentos tecnológicos concretos.

\subsection{Antecedentes}

O AUV Pirajuba possuía uma abordagem de controle híbrida, seguindo a arquitetura GESAM, proposta em [1] em 2008. Fazia uso de um PC104 com sistema operacional de tempo real (QNX), um barramento ethernet, software desenvolvido usando ferramentas gráficas (Rhapsody) e microprocessadores Rabbit 3000 como interface com os sensores e atuadores. O PC104 lia diretamente as saídas de uma bússola eletrônica e de uma unidade de medição inercial por meio de duas portas RS232.

Essa arquitetura, que possuía uma metodologia rigorosa de desenvolvimento de software, usando uma linguagem gráfica, foi pensada para a aplicação em veículos autônomos, que precisam resolver problemas de navegação, guiagem e controle. Na aplicação de identificação dinâmica foram observadas algumas desvantagens, tais como um grande número de cabos ethernet causando 
congestionamento no limitado espaço interno do veículo, frequentes problemas de maus contatos nos conectores RJ-45 do hub-switch e dificuldade de acesso a componentes para reposição. Somando-se a isso, observou-se que o aprendizado necessário para fazer uma manutenção no sistema demandava um tempo muito longo de treinamento no uso da ferramenta escolhida, incompatível com o tempo disponível que um aluno no curso de graduação fazendo iniciação científica possui.

Essa arquitetura de controle foi concebida como base para um veículo aéreo a ser empregado em uma microempresa. Para esse propósito, essa arquitetura se mostrou adequada com o tempo, pois ela respondia aos requisitos para certificação de software aeronáutico e a empresa conta com pessoal permanente e dedicado.

A Tabela 3 lista os equipamentos usados no AUV Pirajuba para esta primeira versão, que foi muito importante para ganhar experiência e perceber uma série de problemas simples, mas que não são evidentes para quem não tem experiência na área.

Tabela 3 - Equipamentos do AUV Pirajuba

\begin{tabular}{ll}
\hline Sistema & Interface \\
\hline IMU VG600AA 202 & RS232 \\
\cline { 2 - 2 } & Analógica \\
\hline Bússola TCM2 & RS232 \\
\hline Servos Rádio Controle & Digital \\
\cline { 2 - 2 } & Analógica \\
\hline Sensor Pressão MLH & Analógica \\
\hline Servomotor Maxon & Analógica \\
\hline Giroscópio KVH & Analógica \\
\hline Sensor de presença de líquido & Digital \\
\hline Acelerômetros ADXL & RS232 \\
\hline Odômetro Doppler - DVL & RS232 \\
\hline Modem de Rádio Frequência & RS232 \\
\hline
\end{tabular}

Devido ao problema de continuidade do desenvolvimento, decidiu-se optar por uma arquitetura mais simples e que pudesse ser mantida por alunos sem experiência em engenharia de software e com pouco tempo de formação, permitindo acumular o conhecimento no laboratório.

\subsection{Características desejadas}

Neste item são apresentadas as características que a arquitetura de controle a ser produzida deve ter, enunciadas pelo orientador. São elas: 
Modularidade: A arquitetura de controle deve ser modular, para tirar proveito do exposto na seção 3.225, com uma interface de dados bem definida e padronizada, com uma alimentação elétrica também padronizada (item 3.5).

Robustez: Devem-se empregar componentes compactos e robustos ao manuseio, com intertravamentos mecânicos para impedir erros de montagem que venham a danificar o material.

Facilidade de desenvolvimento: Para o desenvolvimento do software, deve-se empregar ferramentas de amplo conhecimento pelo mercado e pelo meio acadêmico, de modo que não seja necessário empregar pessoal com alta qualificação. $O$ uso de ferramentas já bem conhecidas permite também aproveitar a experiência contida em padrões de desenvolvimento de código, tornando-o mais fácil de manter e de atingir um grau de segurança.

Baixo custo: Quanto ao hardware, é importante que os componentes estejam disponíveis no mercado local, tenham um baixo custo e que sejam utilizados em larga escala na indústria. É desejável que os componentes sejam padronizados para facilitar a logística.

Baixo consumo energético: um veículo autônomo submarino tem uma reserva de energia bastante limitada. Assim sendo, toda economia de energia resulta em um aumento de raio de ação e autonomia. Existe um ganho extra que é a eliminação de uma grande fonte de calor dentro do veículo, que acarreta um aumento na corrosão das placas de circuito impresso, reduzindo a confiabilidade.

Pequeno volume: o espaço dentro de um veículo submarino é sempre limitado. Todos os seus componentes devem ser o mais compactos possível, devendo caber dentro de um cubo de lado de $10 \mathrm{~cm}$.

Baixo tempo de desenvolvimento: entende-se por tempo de desenvolvimento o intervalo de tempo entre o início do projeto e o término de sua implementação. Concorrem para esse objetivo vários conceitos, tais como reuso, desenvolvimento paralelo, padronização e robustez.

Alta segurança e disponibilidade: Apesar de não envolver risco à vida humana, uma perda de veículo seria um revés significativo para o laboratório. Assim, cuidados devem ser tomados para evitar a perda de um veículo e assegurar que a arquitetura de controle não seja um ponto fraco na confiabilidade do veículo.

Expansibilidade: a arquitetura de controle deve ser capaz de incorporar novos sensores e atuadores, bem como novas funcionalidades. 
Flexibilidade: a arquitetura deve ser adaptável a novas aplicações, de maneira a manter o mesmo padrão para desenvolvimentos futuros.

Continuidade do desenvolvimento: Assegurar que novos alunos tenham condições de compreender o sistema em curto prazo, modificar e adicionar novos subsistemas. Deve-se buscar a orientação a objetos para permitir o reuso e diminuir o tempo de desenvolvimento no futuro. Para viabilizar a modularidade das tarefas sendo executadas, é desejável o uso de um sistema operacional, pois um software desenvolvido sem o suporte de um sistema operacional (foreground / background) não pode ser facilmente dividido em módulos [52].

As tarefas que a arquitetura de controle deve efetuar são:

1. controle da propulsão;

2. atuação das superfícies de controle;

3. aquisição da tensão nas baterias, corrente no servomotor de propulsão, profundidade, sinais da IMU e Bússola;

4. Processamento de dados que permita a execução de manobras simples - manobra de giro e zig-zag;

5. armazenamento de dados; e

6. comunicação com uma estação-base

O desenvolvimento da arquitetura de controle deve seguir as seguintes etapas:

1. estabelecer uma concepção de arquitetura de controle levando em consideração a realidade do laboratório, os custos, a disponibilidade dos componentes, a confiabilidade de hardware e software, o tempo de treinamento mínimo para o pessoal envolvido, a velocidade de implementação, a extensibilidade e a generalidade.

2. definir o hardware a ser usado, projetando placas e escolhendo conectores e cabeamento.

3. elaboração da estrutura do software embarcado.

4. implementação e testes de bancada, seguidos de testes em campo. 


\subsection{Desenvolvimento conceitual}

O texto a seguir mostra passo a passo as decisões tomadas durante 0 desenvolvimento da arquitetura, como as características foram tratadas, bem como sua justificativa ou antecedente histórico.

\subsubsection{Escolha do método de desenvolvimento}

O sistema de controle de um AUV é uma parte vital, ou seja, sem ele, o AUV não pode funcionar. Adicionalmente, envolve um tempo relativamente longo de desenvolvimento se comparado ao projeto do AUV como um todo e tem interações com a arquitetura do AUV, afetando peso, volume, confiabilidade e consumo elétrico.

Não existem muitas empresas no país dispostas a participar de um projeto dessa envergadura, tendo em vista que a maioria das empresas relacionadas à automação não tem experiência na área marítima ou trabalha apenas com grandes clientes.

Além disso, o sistema de controle deve ser flexível e se adaptar a futuras gerações do veículo. Assim sendo, o sistema de controle deverá ser continuamente modificado e atualizado para cada projeto. Não é um produto que pode ser especificado, comprado e entregue uma única vez.

À luz desses fatos e do exposto na seção 3.6, chega-se à conclusão de que o desenvolvimento do sistema de controle do AUV deve ser de responsabilidade dos recursos humanos próprios do laboratório. Por outro lado, esbarra-se no problema da obtenção e qualificação do pessoal, ferramentas e material necessário.

Uma vez que a grande maioria do pessoal não é permanente, não se pode usar ferramentas que requeiram treinamentos longos e que estejam dentro do conhecimento da maioria. Os materiais usados tem que ser facilmente comprados, custar pouco individualmente e ser robustos, haja vista que o pessoal a ser empregado é, em sua grande maioria, inexperiente. Uma vez que a figura do professor é permanente, as competências mais sofisticadas devem ser dominadas pelo professor, tais como a maneira de gerenciar o projeto, a criação de subsistemas, definição das interfaces, definição da missão, identificação de competências a serem adquiridas e gerenciamento de configurações.

Para reduzir o tempo de desenvolvimento, a solução a ser adotada é o desenvolvimento para reuso. Isso significa que os componentes devem ser superdimensionados para acomodar futuras expansões e deve ser desenvolvido um conjunto de opções que abranjam a grande maioria de tarefas que um sistema de 
controle de um AUV pode fazer. Deve ser mantido um tipo de interface único de modo que os componentes sejam intercambiáveis e sejam facilmente reaproveitados em outros projetos. A definição de interfaces simples também ajudará no desenvolvimento de novos componentes e no desenvolvimento em paralelo.

\subsubsection{Modularidade}

A base da arquitetura é a ideia proposta por [5], e similar ao desenvolvido em [36], que é empregar uma rede CAN ligando vários microprocessadores que gerenciam sensores e atuadores e um nó de processamento central capaz de fazer cálculos mais complexos, tais como navegação, mapeamento e planejamento de trajetória, conforme representado na Figura 4.

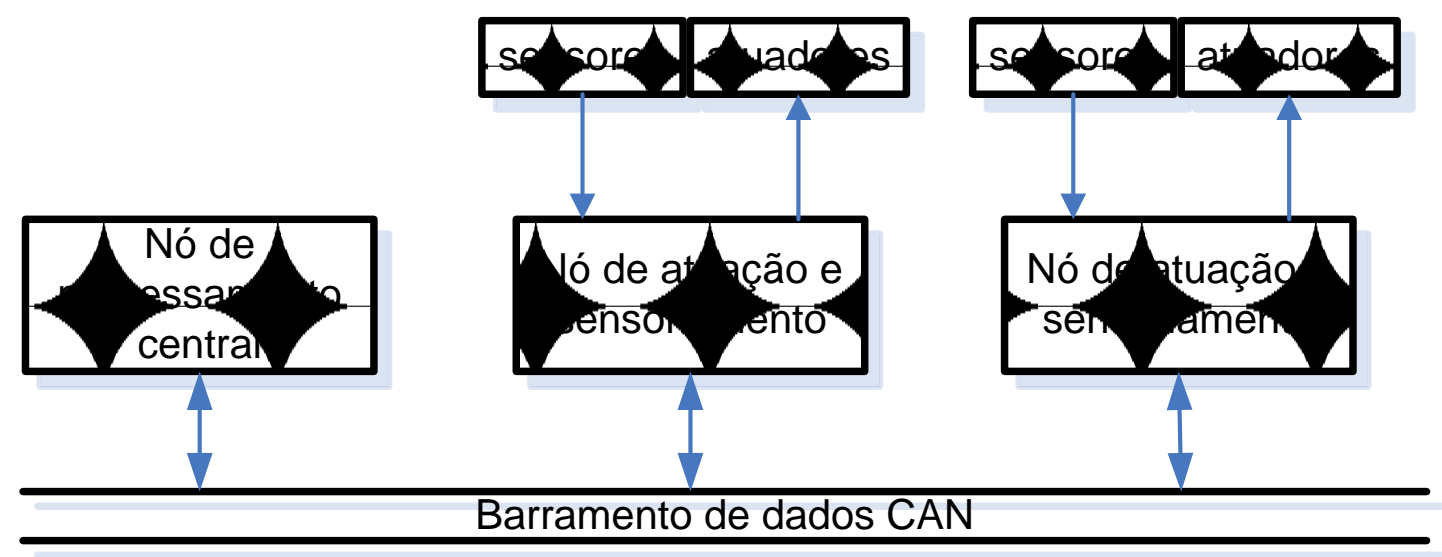

Figura 4 Arquitetura baseada em rede CAN. Traduzido de [5].

O uso de uma arquitetura centralizada foi descartado pelas seguintes razões:

- Introduzir novos sensores a posteriori (item 4.3 - expansibilidade);

- Criar subsistemas simples com interfaces definidas que possam ser feitos por um único responsável (item 4.3 - modularidade);

- Distribuir o processamento entre vários nós à medida que o sistema for crescendo (item 4.3 - flexibilidade);

- Facilitar a consecução das metas de resposta temporal (item 4.3 facilidade de desenvolvimento);

- Facilitar a melhoria da confiabilidade, reduzindo as possíveis falhas de modo comum (item 4.3 - alta segurança e disponibilidade).

Levando em conta as experiências anteriores com ethernet e a análise dos autores vista na revisão bibliográfica, foi decidido, com o fim de aumentar a confiabilidade, a robustez mecânica, diminuir o custo, diminuir o tempo para obtenção de sobressalentes, reduzir os cabos e o volume de bordo, abandonar por 
hora o uso de ethernet e adotar uma rede CAN. Além disso, é uma tecnologia usada na indústria automobilística, o que assegura sua permanência no mercado por um longo tempo.

Considera-se que a rede CAN é bem mais simples, necessitando apenas de um barramento de dois fios, enquanto que a rede Ethernet requer um hub switch ao qual todos os nós são ligados, produzindo fisicamente uma rede na forma de estrela, além de exigir um cabo com mais fios.

Atualmente o AUV Pirajuba possui dez sensores e atuadores usados para a execução de diversas manobras para testar teorias hidrodinâmicas. Todos emitem dados a $10 \mathrm{~Hz}$, sendo que o tamanho da mensagem de cada sensor ou atuador pode ser assumida conservativamente como de oito bytes. Fazendo a multiplicação, a taxa de transmissão de dados fica por volta de 6,4kbit/s, enquanto que a rede CAN pode atingir $1 \mathrm{Mbit} / \mathrm{s}$. Por meio dessa análise superficial pode-se afirmar que, para essa aplicação, a rede CAN é satisfatória para o presente AUV e permite ainda futuras expansões.

Pode parecer um sobredimensionamento empregar vários nós de processamento sendo que apenas um nó central poderia ser capaz de atender aos requisitos, porém o desenvolvimento fica mais fácil de ser gerenciado, tal como visto na seção 3.2. A interface entre os subsistemas fica bastante simples, permite-se o trabalho em paralelo em vários subsistemas, cada desenvolvedor tem uma boa autonomia e tem a responsabilidade bem definida e limitada, bem como se permite que a experiência anterior possa ser aproveitada ou que o aluno desenvolva uma determinada competência que seja de seu interesse.

Assim, após informado ao aluno as especificações básicas de seu módulo, descritas na seção 3.2 (comportamento geral do AUV, propósito do módulo, desempenhos a serem atingidos, tais como resposta temporal e frequência de amostragem, e interfaces - alimentação elétrica, conectores, protocolo de comunicação, taxa de transmissão máxima), ele pode executar o desenvolvimento do mesmo sem maiores empecilhos.

Para permitir a modularidade do software, ou seja, para evitar que uma modificação em uma parte do software cause diretamente problemas em outras partes do software, tal como ocorre em um sistema foreground / background [52], deverá ser adotado um sistema operacional, que por sua vez, proverá uma 
infraestrutura para facilitar o desenvolvimento. Para facilitar o reuso e a organização, deverá ser adotada uma filosofia de orientação a objetos.

A arquitetura modular facilita estabelecer um único responsável por funcionalidade, o que por sua vez permite identificar de maneira imediata problemas de ordem técnica e gerencial, permitindo soluções rápidas para ambos.

\subsubsection{Classificação funcional}

Para tirar proveito das ideias contidas na seção 3.4, que é atingir o grau mínimo de segurança com um esforço reduzido, decidiu-se estabelecer dois níveis de segurança. Os nós de processamento que potencialmente afetam a sobrevivência do AUV deverão ser desenvolvidos com um padrão de qualidade mais elevado e empregar um hardware mais robusto. Outros sistemas serão desenvolvidos sem imposições de hardware ou padrões de programação.

Para atingir a qualidade de software nos equipamentos críticos, pretende-se adotar a MISRA-C, pois esta norma provê uma série de recomendações que tornam o código mais legível, evitam os problemas mais conhecidos da linguagem e tornam mais raros os erros de falha humana.

O projeto dos componentes de hardware será norteado pelas recomendações contidas em [49]. Assim, aproveita-se o conhecimento já acumulado em outras aplicações para benefício desse projeto, tal como sugere a seção 3.7.

\subsubsection{Gerenciamento de interfaces}

As interfaces devem ser rigidamente controladas para manter a consistência da arquitetura de controle como um todo, não sendo jamais permitido que um desenvolvedor altere o tipo de conector, protocolo, o volume da caixa que encapsula cada nó empregado ou a ferramenta de desenvolvimento, de maneira a evitar os problemas apontados na seção 3.5, que é o retrabalho em todos os outros sistemas e a inconsistência com o resto da arquitetura.

\subsubsection{Integração, verificação e validação}

Como previsto na seção 3.9, uma arquitetura modular requer um procedimento padrão de integração, verificação e validação, descrito a seguir: ao receber a sua tarefa de desenvolvimento, cada programador receberá também o objeto a ser controlado ou monitorado, e trabalhará sozinho nesta atividade. Após desenvolver o código, o programador deverá validar o funcionamento isolado do seu módulo. Caso seja um módulo crítico, deve-se verificar também se o software atende aos critérios da norma em vigor. Finalmente, deve-se integrar o módulo à rede CAN, 
verificando-se o funcionamento em paralelo com todos os outros módulos. Sugerese que esta última etapa deva ser executada sob supervisão de alguém com experiência no desenvolvimento e utilização da arquitetura, de modo a diminuir a probabilidade de erros que levem a danos ao AUV.

\subsubsection{Gerenciamento de configurações}

Dada a complexidade do AUV, é importante fazer o gerenciamento de configurações, como previsto na seção 3.10, que é manter, para cada versão pronta do AUV, a lista de software e hardware empregados. Isso é fundamental caso surjam problemas de interação entre módulos durante a vida útil do veículo após uma modificação simultânea em vários módulos.

\subsubsection{Plano tecnológico}

Microprocessadores possuem hoje um extenso leque de opções para sua programação, que inclui comumente ferramentas gratuitas. A linguagem mais comum é o ANSI C, existindo até sistemas operacionais codificados em C. Além disso, C faz parte do currículo em muitas universidades e é uma linguagem próxima da linguagem de máquina, que gera um código eficiente. Por isso, foi adotada a linguagem $\mathrm{C}$ e o ECLIPSE com o plugin CDT como ambiente de desenvolvimento, e - GNU-GCC como compilador. Tais ferramentas foram escolhidas por serem gratuitas, abertas, de fácil uso e conhecidas. Impor o uso de uma única ferramenta e ambiente de desenvolvimento facilita a manutenção do código, uma vez que os diversos alunos ficam acostumados com as mesmas ferramentas, permitindo a transferência de responsabilidade de um desenvolvedor para outro com um tempo de aprendizado pequeno. De certa maneira, essa escolha (e limitação) das ferramentas a serem empregadas funciona de maneira similar a um plano tecnológico, com as vantagens vistas na seção 3.8. Seguindo ainda a ideia de plano tecnológico, a arquitetura de hardware será baseada em um pequeno número de tipos de placas que podem ser empilhadas, com um barramento paralelo vertical, de maneira similar ao padrão PC-104 e de maneira que cada módulo possa ter todas as funcionalidades necessárias.

Ainda que a arquitetura seja modular per si, cada módulo se trata de um projeto de software que pode adquirir um tamanho considerável com o passar do tempo e receber novas funcionalidades e equipamentos, visto que o hardware deverá permitir expansões futuras. Por isso, uma dose de disciplina no desenvolvimento da arquitetura de software se faz necessária, no sentido de permitir 
a modularidade e verificação do código gerado. Embora a linguagem $C$ não tenha sido feita de modo a prever o uso de modo orientado a objetos, é possível usar alguns conceitos básicos como encapsulamento, agrupamento simultâneo de atributos e métodos e visibilidade [50]. Dessa forma é possível deixar o código bastante modular e fácil de ser verificado.

Decidiu-se empregar um sistema operacional para facilitar a modularidade e a orientação a objetos dentro de cada módulo, permitindo que o desenvolvedor possa dividir o trabalho em várias tarefas independentes, evitando problemas de interação. O sistema operacional adotado, seguindo [36], foi o $\mu \mathrm{C}$-OSII, levando-se em consideração o fato de ser aberto e gratuito para universidades, além de ser embarcável em microprocessadores.

O $\mu \mathrm{C}$-OSII tem uma estrutura bastante simples e é bastante didático, para alunos de iniciação científica, em termos conceituais de sistemas operacionais. Vale a pena ressaltar que é um sistema operacional preemptivo de tempo real, certificado para equipamentos médicos e aeronáuticos que, de acordo com o julgamento ora feito, permite elevar a confiabilidade e a facilidade de manutenção dos softwares gerados. Pode-se ainda lembrar que softwares desenvolvidos em sistemas de plano de frente e de fundo (um laço infinito e diversas funções de interrupção), do inglês foreground/background, não possuem modularidade, ou seja, uma alteração em uma parte do código pode afetar o funcionamento de outra, prejudicando muito a flexibilidade e a manutenção. Com um sistema operacional de tempo real confiável, é possível dividir cada tarefa em módulos totalmente independentes entre si, facilitando o projeto do software, simplificando o código e facilitando a manutenção.

Outra alternativa, bastante empregada, seria o LINUX. Entretanto, o LINUX possui várias versões e não tem certificação de tempo real. Além disso, o espaço de memória necessário seria bem maior, requerendo processadores de maior poder de processamento e de armazenamento de dados. Outro problema seria a portabilidade do sistema operacional para outras placas, já que seriam necessários maiores esforços para tal, haja vista maior complexidade.

Para a documentação deverão ser criados documentos explicando o funcionamento geral de cada componente criado. Complementarmente, deverá ser feita uma documentação no código fonte, explicando passo a passo a lógica adotada. 
Tal documentação deverá ser criada obedecendo à sintaxe do DOXYGEN, que é uma ferramenta automática de geração de documentação. O DOXYGEN permite criar, a partir dos arquivos de código fonte adequadamente comentados segundo uma sintaxe específica, uma série de páginas *.html que apresentam a visão geral arquivos de código fonte, das funções existentes, a relação entre elas, os argumentos de entrada e a visualização do código fonte, tudo com uma navegação rápida e fácil, com uma apresentação clara e esteticamente agradável.

\subsubsection{Referencial normativo}

Para dar consistência ao projeto, a programação dos módulos deverá seguir as diretrizes contidas na MISRA $C$ e no padrão Netrino para reduzir a quantidade de bugs, agilizar a leitura do código e tornar o desenvolvimento mais robusto. Para a confecção das placas, adota-se as recomendações da Texas Instruments [49], que já foram testadas e, apesar de sua simplicidade, têm produzidos bons resultados.

Tais referências são simples e de fácil leitura por parte de alunos de graduação, por exemplo. Assim, espera-se que o projeto tenha uma solidez maior, dadas as restrições de tempo dos colaboradores, que não tem condições de estudar conteúdos muito profundos.

\subsection{Arquitetura de hardware embarcado}

Dadas as circunstâncias e os equipamentos disponíveis, percebeu-se que era necessário o uso de microprocessadores para fazer a inicialização de alguns sensores, fazer a conversão de protocolos, e estabelecer a interface com o usuário. $\mathrm{O}$ uso de microprocessadores de 8 bits resolve quase todas as necessidades, porém não permite uma expansão do firmware embarcado. $O$ preço de um microprocessador de 32 bits é similar ao de outro de 8 bits com recursos semelhantes de memória volátil e não volátil, porém tem mais periféricos e um poder computacional bem mais elevado por ser de uma arquitetura mais moderna e efetuar contas de 32 bits em um único ciclo de relógio.

Foi cogitada a opção de empregar placas com processadores capazes de embarcar sistemas operacionais tais como Linux ou QNX. Porém, não foi encontrado no mercado alguma placa que possuísse todos os periféricos requeridos para a interface com os sensores e atuadores. De maneira geral, foi observado que tais placas podem possuir conversores analógico-digitais, geradores de PWM e conversores digital-analógicos, porém sempre em pequena quantidade e nunca todos esses periféricos em uma única placa. Por outro lado, essas placas possuem 
muitas entradas e saídas para transmissão de altas taxas de dados, tais como ethernet e USB, como pode ser observado na Tabela 4.

Tabela 4 - Comparação entre algumas placas disponíveis no mercado na época do estudo

\begin{tabular}{lrrrrrrr}
\hline Nome & D/A & A/D & PWM & Ethernet & USB & UART & Clock \\
\hline eLPC64 (baseado no LPC2148) & 1 & 10 & 6 & 0 & 1 & 2 & $48 \mathrm{MHz}$ \\
\hline BeagleBone Black & 0 & 7 & 0 & 1 & 1 & 4 & $1 \mathrm{GHz}$ \\
\hline Arduino Mega 2560 & 0 & 16 & 15 & 0 & 1 & 4 & $16 \mathrm{MHz}$ \\
\hline CM-FX6 Computer-On-Module & 0 & 0 & 0 & 1 & 5 & 5 & $1.2 \mathrm{GHz}$ \\
\hline TS-7800 500MHz Series & 0 & 5 & 0 & 1 & 2 & 10 & $500 \mathrm{MHz}$ \\
\hline
\end{tabular}

Foi escolhido o LPC2148 da NXP semiconductors, que possui arquitetura ARM7 e que apresenta melhor relação custo-benefício em termos de memória permanente, memória volátil e número de periféricos. Oferece ainda a disponibilidade imediata de módulos produzidos no País a um baixo custo. Uma vez que esse microprocessador possuía recursos de hardware que possibilitava a interface com todos os equipamentos disponíveis, seria necessário apenas um modelo de hardware para todas as tarefas, reduzindo o tempo de aprendizado. Além disso, o poder computacional desse hardware já permite a aplicação de filtros mais elementares e tarefas mais complexas.

Dadas as limitações do número de entradas e saídas de cada unidade do microprocessador, é necessário contar com várias unidades, distribuindo as tarefas. A comunicação entre cada subsistema se dá por meio de uma rede CAN. O veículo conta com três vasos estanques onde são colocados os equipamentos. $O$ vaso mais a ré é o de propulsão, que possui apenas o motor e um sensor de presença de líquido. Há um vaso que protege os servos $\mathrm{RC}$ e o driver do servomotor de propulsão. Neste vaso estão montadas as superfícies de controle.

O maior vaso é chamado de principal, pois tem maior quantidade de sensores, leva as baterias que alimentam o veículo e faz a comunicação com a estação base, como visto na Figura 5 . 


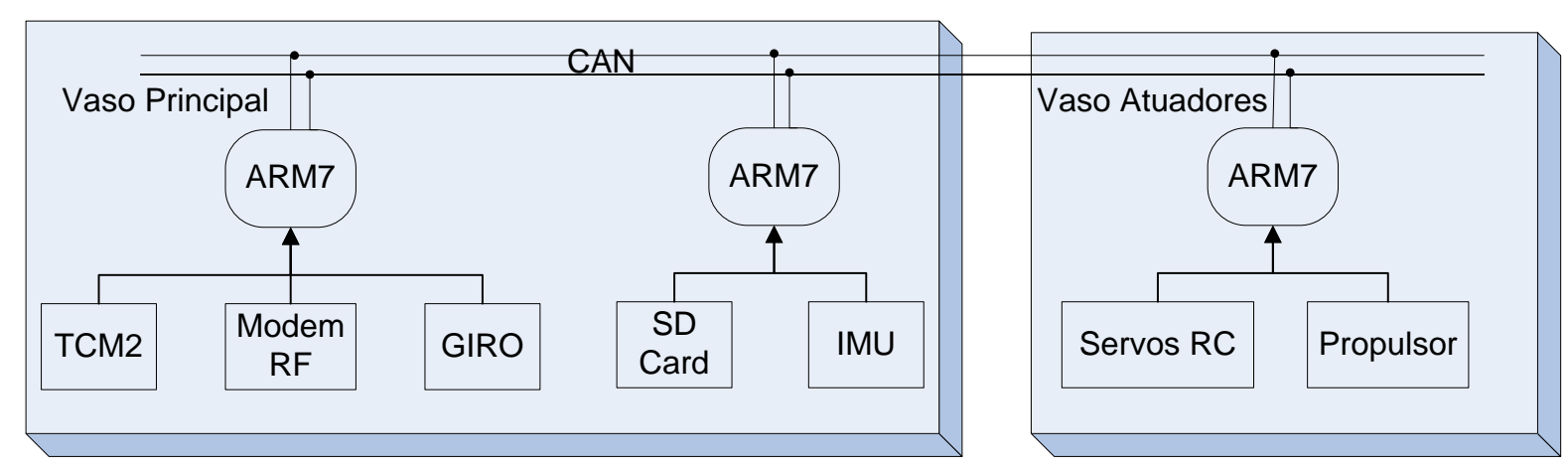

Figura 5 Diagrama de blocos simplificado do AUV Pirajuba

\subsubsection{Circuitos de condicionamento e conversão de sinais}

O LPC2148 trabalha com tensões na faixa de 0 a 3.3V. Entretanto, há equipamentos com sinais de diferentes tensões, tais como $\pm 10 \mathrm{~V}, 0-5 \mathrm{~V}, 0-33 \mathrm{~V}$, RS232 ( $\pm 15 \mathrm{~V})$. Para contornar esse problema, foram usados amplificadores operacionais, amplificadores de instrumentação e divisores de tensão resistivos. Os sinais de $\pm 10 \mathrm{~V}$ que são fornecidos pelo driver do servomotor de propulsão foram convertidos para a escala de 0 a $3.3 \mathrm{~V}$ com um circuito do tipo amplificador inversor seguido de um filtro passivo para que pudesse ser feita a A/D.

Para gerar a ordem de rotação para o driver de $\pm 10 \mathrm{~V}$ a partir do DAC do LPC2148, foi usado um circuito de amplificação e deslocamento do sinal composto de um INA126. O servomotor possui ainda um sinal para habilitá-lo, que impede o seu funcionamento caso esteja a uma tensão abaixo de 4V. Uma vez que o nível alto de tensão do microprocessador é 3.3V, foi necessário usar um transistor e um pino do tipo dreno-aberto (quando o nível lógico é 1, o pino se comporta como se estivesse isolado; quando o nível lógico é 0 , o pino está ligado na terra) para fazer a habilitação ou desabilitação desse atuador por software.

Quanto aos outros sinais, foram usados divisores de tensão resistivos. Para a conversão dos sinais TTL para RS232, foram usados circuitos integrados MAX232 em encapsulamentos SMD.

\subsubsection{Controlador de rede}

Para fazer o controle da rede CAN, foi usado o circuito integrado MCP2515 da Microchip, em conjunto com o transceiver MCP2551 do mesmo fabricante. Esse $\mathrm{Cl}$ tem dois buffers para recepção e três para transmissão. Usa um protocolo SPI com frequência de até $10 \mathrm{MHz}$ para comunicação com o microprocessador. Possui ainda 
um pino que gera uma interrupção no microprocessador em caso de um evento qualquer. Permite que os dados trafeguem no barramento CAN com frequência de até $1 \mathrm{MHz}$, o que é bem maior do que a necessidade atual. Ao fazer a soma de todos os dados a ser transmitidos pela rede no espaço de tempo de 1 segundo, a largura de banda utilizada é inferior a $5 \%$ da banda disponível com o barramento a $1 \mathrm{MHz}$. Devido a isso, atualmente, o barramento vem sendo usado a $500 \mathrm{kHz}$ com o objetivo de reduzir o número de erros.

Esse $\mathrm{Cl}$, após ser inicializado e propriamente configurado pelo microprocessador, faz todo o trabalho de baixo nível preconizado pelo padrão CAN, tal como verificação de erros das mensagens recebidas, filtragem das mensagens indesejadas e retransmissão das mensagens perdidas. Tudo isso liberta o programador de ter que resolver esses problemas por software, permitindo que, após a codificação de um software de baixo nível para controlar esse $\mathrm{Cl}$, basta fazer uso de funções para enviar e receber mensagens. A título de informação, a possibilidade de que passe despercebido um único bit errado em uma mensagem CAN é da ordem de $10^{-14}$ [28].

\subsubsection{Considerações de confiabilidade}

Foi observada a presença de umidade dentro dos vasos de pressão da primeira versão do veículo apesar do mesmo ter passado nos testes de estanqueidade. Uma vez que existe a presença de muitos equipamentos eletrônicos, a exposição à água em forma de vapor é bastante preocupante em termos de confiabilidade. Se for considerado que essa arquitetura se destina ao uso no mar, existe a complicação da contaminação iônica, que diminui ainda mais o tempo médio entre falhas. Para dar uma ideia quantitativa de quanto é essa diminuição na vida do equipamento, recorre-se ao modelo de Peck [29], que fornece o fator de aceleração da reação de oxidação de um componente eletrônico em função da umidade e temperatura, visto na equação (1).

$$
A_{k}=\left(\frac{H_{d e}}{H_{d u}}\right)^{2.66} \times e^{\frac{E_{a}}{k}\left(\frac{1}{T_{j u}}-\frac{1}{T_{j e}}\right)}
$$

Onde:

$A_{k}=$ Fator de aceleração da reação.

$H_{d e}=$ Umidade relativa no dispositivo em condições de ensaio. 
$H_{d u}=$ Umidade relativa no dispositivo em condições de uso .

$E_{a}=$ Energia de ativação. Para circuitos integrados fica em torno de 0.7 elétrons-volt.

$T_{j u}=$ Temperatura no interior do dispositivo em condições de uso.

$T_{j e}=$ Temperatura no interior do dispositivo em condições de ensaio.

$k=$ Constante de Boltzman $\left(\mathrm{k}=8.62 \times 10^{-5} \mathrm{eV} / \mathrm{K}\right)$.

De acordo com esse modelo, para uma elevação de temperatura de $20^{\circ} \mathrm{C}$ para $70^{\circ} \mathrm{C}$, há uma redução no tempo de vida de cerca de 10 vezes, mantendo a umidade constante. $O$ efeito do aumento da umidade relativa ainda é mais dramático. Para uma atmosfera com 10\% de umidade relativa como referência, há uma redução de cerca de 450 vezes no tempo de vida do equipamento exposto a uma atmosfera saturada com vapor. Ainda não foi levada em conta a contaminação iônica devido à salinidade da água do mar.

Pode-se então afirmar que a proteção dos circuitos eletrônicos é muito importante para obter confiabilidade do sistema como um todo. A primeira medida tomada foi a adoção de caixas plásticas lacráveis para isolar a atmosfera dos componentes eletrônicos do resto do vaso de pressão, como mostra a Figura 6.

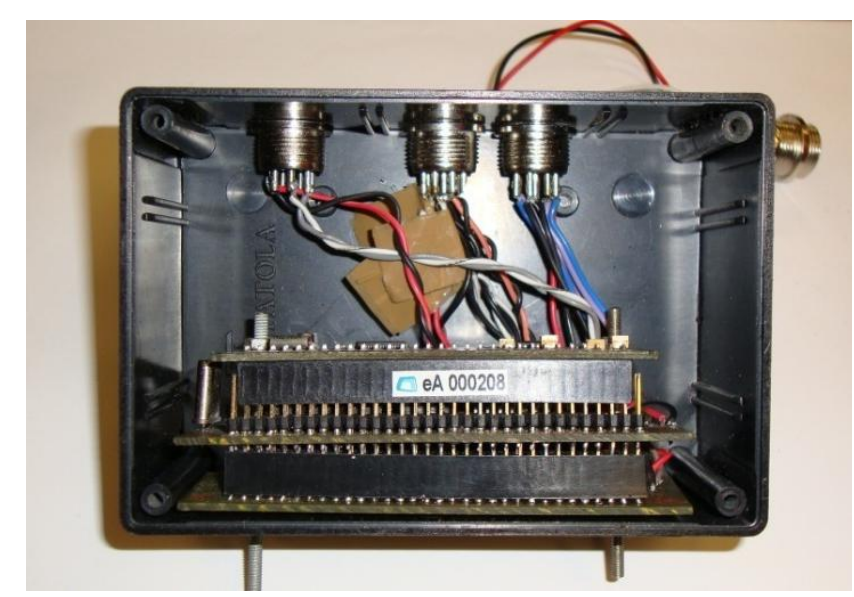

Figura 6 Caixa protetora dos circuitos eletrônicos

Assim, fica efetiva a colocação de sacos de sílica para absorver a umidade local interna da caixa. Depois, na confecção das placas de circuito impresso foram usadas trilhas de maior largura do que o normalmente usado. Para ilustrar, a largura padrão das trilhas normalmente usadas é 10 milésimos de polegada, enquanto a 
menor trilha usada foi de 30 milésimos. Assim, aumenta-se a área a ser corroída até que haja a falha.

Outra medida foi a retirada de todas as fontes de calor significativas de dentro das caixas de proteção, tais como reguladores de tensão. O circuito que mais dissipa calor é o próprio microprocessador, que, conforme observado em laboratório, sofre um aquecimento muito leve devido à própria dissipação. Mais uma medida protetora é a aplicação de verniz sobre as placas prontas, de modo a proteger as trilhas e os pinos dos circuitos integrados da atmosfera circundante.

\subsubsection{Considerações de robustez mecânica}

Um dos problemas mais difíceis de resolver em sistemas embarcados são os contatos elétricos de má qualidade caso sejam usados conectores inapropriados. Em sistemas em fase de desenvolvimento isso é ainda mais crítico, pois o manuseio das peças é constante devido às frequentes mudanças de configuração e testes.

Para conferir flexibilidade e facilidade de confecção das placas de circuito impresso, foi concebido um padrão de placas auxiliares com dimensões similares à dos subsistemas que contém os microprocessadores e que possuem um conector similar aos do padrão PC-104, com um conector DIN fêmea com 64 pinos embaixo e uma barra de pinos dupla em cima. Dessa forma, cada nó fica composto por uma pilha de placas e todos os pinos do módulo têm acesso a todas as placas da pilha. Em outras palavras, há um barramento de 60 pinos (o módulo com 0 microprocessador possui 60 pinos) e mais 4 pinos extras para comunicação entre as placas. A Figura 7 e a Figura 8 mostram as placas que compõem um módulo e 0 módulo montado, respectivamente. 


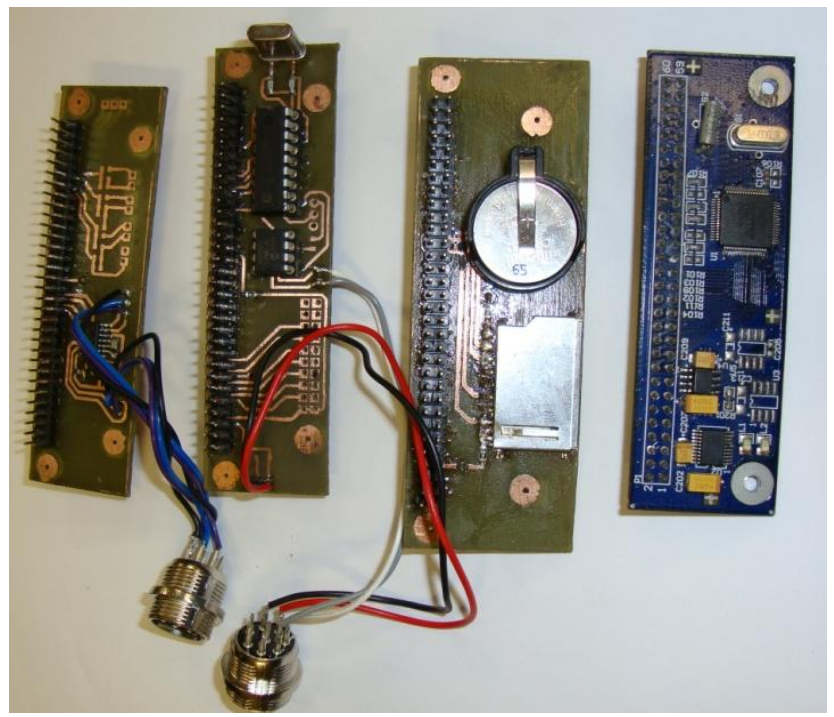

Figura 7 Módulo e-LPC64 e placas corroídas

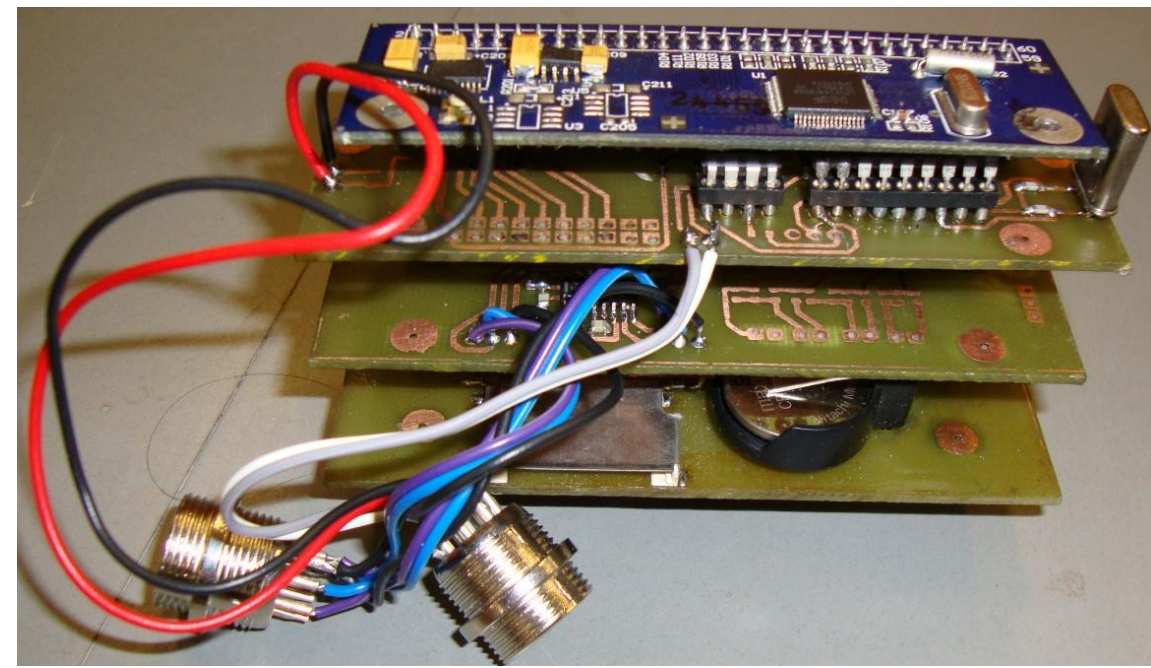

Figura 8 Pilha de placas com o módulo eLPC-64, placa com driver CAN, placa serial RS232 e placa com bateria e cartão de memória

Uma vez que o conector tem um grande número de pinos, a conexão entre as placas fica bastante robusta, expondo cada pino, individualmente, a menores esforços de flexão. Para deixar o sistema ainda mais robusto, e aproveitando a própria concepção do módulo microprocessado, são passados dois parafusos sem fim com espaçadores na extremidade oposta ao conector, deixando o sistema bastante robusto.

$\mathrm{Na}$ parede da caixa protetora foram colocados conectores padrão automotivo do tipo MIKE (Figura 9) com oito pinos, que possuem formato cilíndrico, o que facilita a abertura do furo para sua colocação. Esses conectores contam com uma 
blindagem metálica e molas bastante robustas. Contam ainda com rosca para garantir sua fixação e são polarizados, ou seja, é impossível a sua colocação em uma orientação errada. Na parte interna, os fios que saem dos conectores machos presos na parede da caixa são soldados diretamente nas placas, eliminando a necessidade de outros conectores e a possibilidade de falhas. Com essas medidas, espera-se reduzir o problema de contatos elétricos.

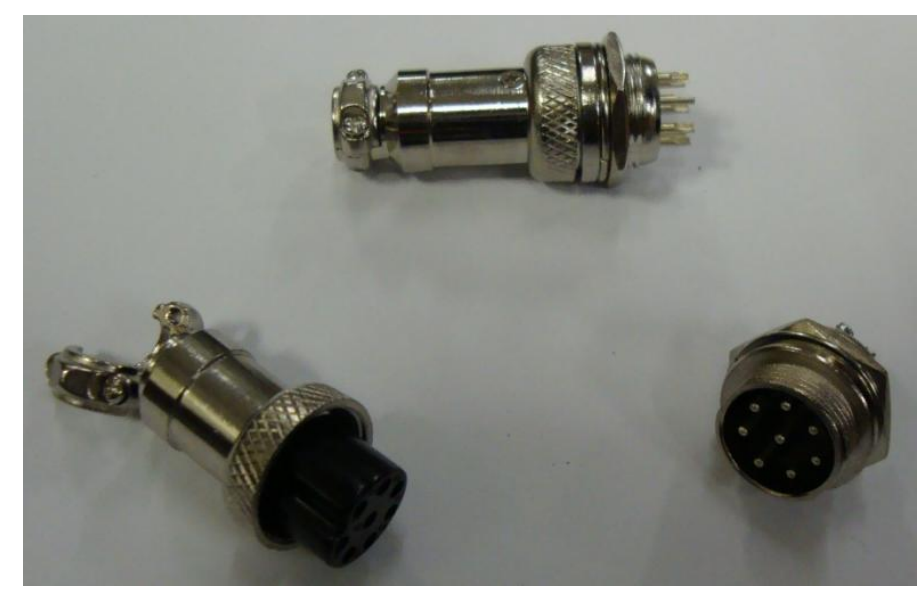

Figura 9 Conectores Mike

\subsubsection{Considerações sobre ruído}

Ao projetar o PCB, alguns cuidados foram tomados para minimizar os ruídos. Foi utilizado um plano de terra na face inferior do circuito, de forma que toda trilha de sinal tenha uma trilha de terra próxima. Tomou-se cuidado para ter o menor número possível de trilhas no plano inferior e, quando necessárias, traçadas pelos cantos da placa para evitar divisões no plano.

$\mathrm{Na}$ escolha dos componentes foi dada preferência aos de encapsulamento SMD, devido à sua menor indutância e por ficarem posicionados mais próximos à placa [49]. Os componentes foram distribuídos em zonas de mesma função, para diminuir a interferência entre as diversas partes do circuito. O cristal do controlador CAN foi posicionado de forma a ficar afastado dos outros componentes por ser uma importante fonte de emissões eletromagnéticas. Os filtros dos sinais dos sensores foram posicionados próximos ao conector do microcontrolador, de forma a filtrar os ruídos captados pela trilha entre o componente e a entrada. As trilhas foram feitas com o menor comprimento possível e as conexões ao terra foram preferencialmente feitas diretamente ao plano da face inferior através de vias, aumentando o isolamento entre os componentes. 
Dessa forma, foi possível reduzir consideravelmente os ruídos das medições, em comparação com as placas usadas para teste, feitas sem essas precauções.

\subsubsection{Confecção das placas}

Para a fabricação das placas do protótipo, foi utilizado o método de transferência térmica, que consiste em imprimir o circuito em transparência numa impressora laser, e depois transferir a para a placa de cobre utilizando calor. Temperaturas muito altas e tempos prolongados de aquecimento fazem com que a transparência se deforme, borrando o desenho. Após a transferência ter sido realizada, a placa foi furada utilizando brocas de $0.9 \mathrm{~mm}$ e as falhas foram retocadas com canetas especiais para circuito impresso. Em seguida, as placas foram corroídas com percloreto de ferro e envernizadas para evitar a oxidação do cobre.

A precisão obtida através desse método é consideravelmente boa para métodos artesanais, permitindo inclusive trilhas passando entre os pinos do conector, que tem um espaçamento de um décimo de polegada. Neste caso, as trilhas foram desenhadas maiores do que o espaço disponível, e após terem sido transferidas ao cobre foram raspadas à mão com um objeto de ponta bem fina e cortante para não entrar em contato com o os pinos.

Após a validação das placas, foi encomendado um grande número de placas, obtendo economia de escala. Uma vez que o preço era dado por placa e não por superfície, foi criada uma única placa grande contendo dezenas de unidades das pequenas placas sendo empregadas na arquitetura.

\subsection{Arquitetura de software}

Neste item, são apresentados a visão geral da arquitetura de software e seus principais elementos.

A ideia central da arquitetura de software é prover uma biblioteca de funções para facilitar posteriores desenvolvimentos de objetos de alto nível. Para organizar a arquitetura, foram definidas camadas, nas quais os objetos podem usar funções dos objetos da própria camada ou das camadas adjacentes. Uma apresentação sumária dos principais objetos e camadas pode ser vista na Figura 10. Essas funções básicas foram desenvolvidas buscando um padrão em consonância com a MISRA-C para prover robustez e confiabilidade.

Para facilitar o entendimento, os módulos de código foram divididos por função e por nível. Na Figura 10, objetos em uma mesma vertical contribuem para uma mesma função. Por exemplo, para a função de armazenamento de dados: o 
objeto SPIO controla a porta serial síncrona que é usada pelo objeto FAT para escrever e ler dados em um cartão de memória $S D$ Card, que por sua vez é empregado pelo objeto Datalog para gravar periodicamente as informações de controle. Esses objetos usam recursos do sistema operacional, tais como criação de tarefas e semáforos. Além disso, o objeto Datalog usa o objeto sharedMemory para obter os dados de controle.

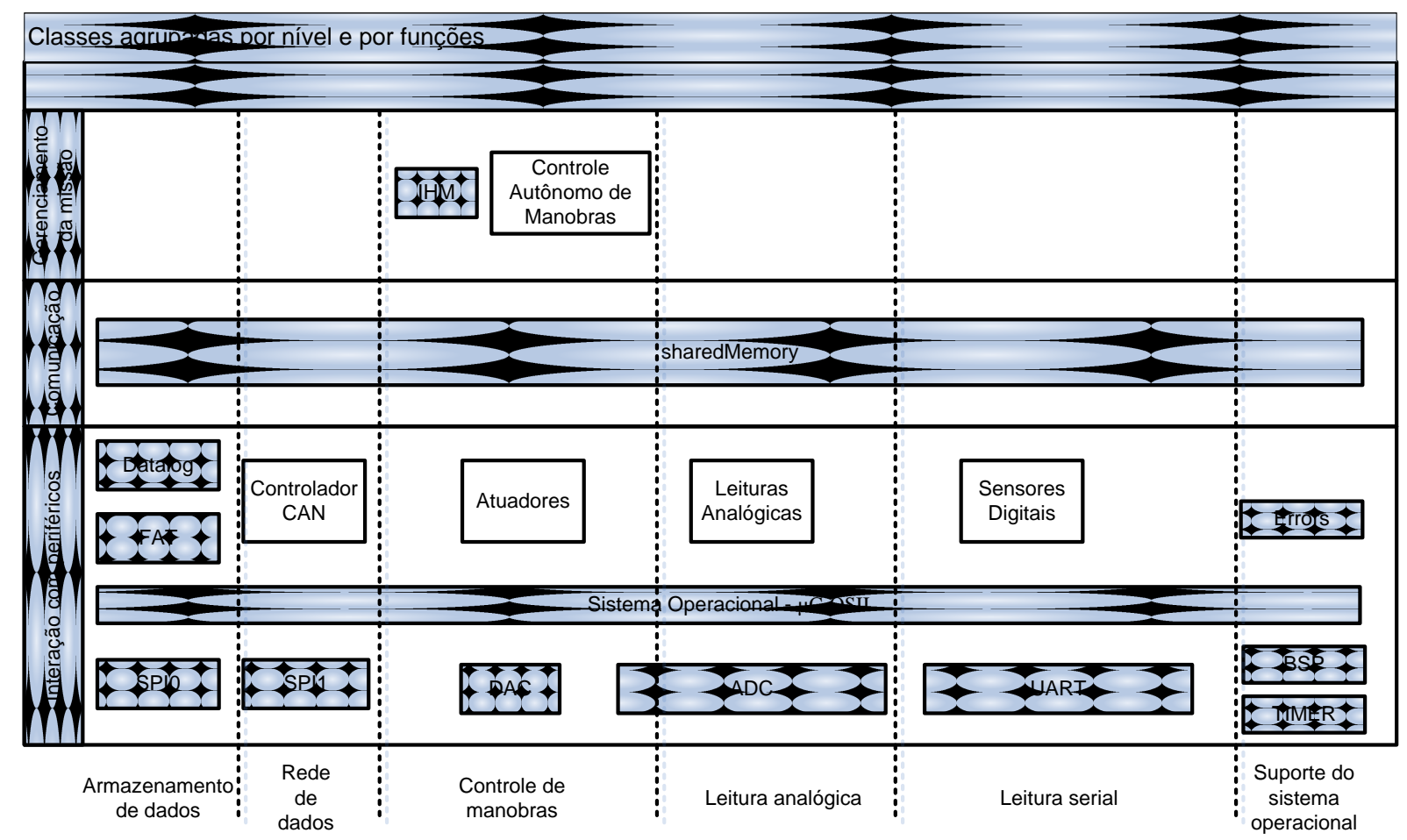

Figura 10 Visão geral do software embarcado. Blocos cinza representam objetos e blocos brancos representam componentes formados de vários objetos.

No nível de interação com periféricos, existem vários tipos de objetos, de certa forma constituindo subcamadas, porém cada objeto pode se comunicar diretamente com todas as outras subcamadas, como o sistema operacional, que se comunica com todos os objetos desta camada:

1. Controladores dos periféricos internos do microprocessador: São usados os registradores de configuração, de entrada e saída de dados. $\mathrm{Na}$ filosofia adotada, cada periférico é um objeto e possui atributos, que são os estados dos periféricos em si, e métodos, que são as funções que obtém os dados ou modificam esses atributos. São os objetos SPI0, SPI1, DAC, ADC, UART, BSP e TIMER da Figura 10. 
2. Sistema operacional: disponibiliza uma série de recursos para os outros objetos, tais como semáforos, possibilidade criação de seções críticas de código, tempos de espera, caixas de correio e temporizadores, criação de threads, entre outros. É o objeto Sistema Operacional - $\mu \mathrm{C}-\mathrm{OSII}$ da Figura 10.

3. Controladores dos periféricos da placa: Esses objetos controlam os recursos da placa, tais como o controlador CAN, condicionadores de sinal e drivers de porta serial assíncrona. Usam os métodos do sistema operacional e dos periféricos internos do microprocessador. Alguns, mais complexos, como a porta serial assíncrona, usam métodos privados de interrupção para tratar a chegada de dados. Outros, além disso, possuem uma tarefa própria, como o controlador CAN. São os objetos Datalog, FAT e Errors e parte dos componentes controlador CAN, Atuadores, Leituras Analógicas e Sensores Digitais da Figura 10.

4. Controladores dos sensores e atuadores do AUV: tem a função de inicializar, controlar e efetuar a leitura dos sensores do AUV e enviar comandos para os atuadores e para o cartão de memória. Tais objetos são necessários porque tipicamente os sensores requerem alguma configuração por ocasião da inicialização do AUV. Além disso, cada tipo de atuador precisa de um tratamento específico para cada caso e, às vezes, de filtros (rampa, filtros de primeira ordem, controladores proporcionais - integrais - derivativos) antes de enviar o comando. São os objetos Datalog e partes dos componentes Atuadores, Leituras Analógicas e Sensores Digitais da Figura 10.

No nível de comunicação, a classe sharedMemory providencia, para todos os objetos, os dados necessários, vindos pela rede ou não. Essa classe, que possui uma instância em cada nó da rede, permite que os objetos relacionados a uma dada função possam ser facilmente transferidos de um nó para outro sem causar complicações do ponto de vista do software, pois ela faz com que todas as informações estejam disponíveis igualmente em todos os nós. A capacidade para transferir uma função de um nó para outro fica limitada unicamente pelos recursos de hardware (portas seriais, placas de condicionamento de sinal) presente nos nós em questão. Tendo em vista que o hardware é modular e facilmente expansível, o 
usuário tem total liberdade para alocar as funções pelos módulos conforme o seu interesse.

Todos os dados obtidos por qualquer objeto é transferido para a instância local da sharedMemory, que os registra e envia pela rede. Todas as instâncias da sharedMemory mantém a última atualização dos dados vindos da rede e, quando ocorre uma nova atualização ou uma perda de comunicação, avisam os objetos que assinaram um determinado dado.

No nível de gerenciamento da missão estão as funções finais do sistema, que é a realização de manobras autônomas.

A seguir, será feita uma descrição breve dos objetos e componentes que constituem o sistema para melhorar o entendimento da estrutura seguida. Os objetos do nível periféricos não serão abordados por ser apenas de configuração e uso de recursos de hardware, dispensando maiores explicações. A única exceção é o objeto BSP.

\subsubsection{Camada de interação com periféricos}

Neste item apresenta-se em detalhes cada um dos objetos da camada de interação com periféricos mostrados na Figura 10.

\section{Objeto BSP}

Do inglês, Board Support Package, oferece ao sistema operacional as funções necessárias ao seu funcionamento, como, por exemplo uma interrupção periódica para chamar a rotina de tick do sistema operacional. Oferece ainda uma estrutura que permite que qualquer outro objeto tenha um método chamado a cada tick. Esse método, que no caso não deve retornar e nem receber nenhum valor, é chamado callback. Uma das utilidades é, por exemplo, a possibilidade de ser feita uma leitura periódica de um sensor com alta frequência sem requerer a existência de uma tarefa para isso. Outra utilidade implementada por esse módulo é uma pilha de códigos de erro. As ações de cada objeto do sistema podem falhar por uma infinidade de razões. Para facilitar o diagnóstico da falha, foi criado um código de erros com um byte de extensão. A cada erro ocorrido, qualquer objeto pode inserir o código correspondente na pilha. Depois, esse código é recuperado e armazenado no objeto datalog e enviado para a estação base.

\section{Objeto sistema operacional - $\mu \mathrm{C}$-OSII}


É composto por uma série de arquivos de código fonte, todos desenvolvidos pela Micrium e disponibilizados gratuitamente para universidades.

Neste objeto são feitos todos os serviços e funções do sistema operacional, que disponibiliza uma série de recursos, tais como semáforos, possibilidade criação de seções críticas de código, tempos de espera, caixas de correio e temporizadores, entre outros. Ele permite também a criação de tarefas que funcionam de maneira independente, facilitando a segregação das diversas porções do código.

\section{Objeto FAT}

Esse objeto implementa rotinas de criação, alteração, apagamento e movimentação de arquivos em uma memória permanente formatada de acordo com o padrão FAT. O interesse, no caso, é usar um SD-card para fazer o armazenamento de dados obtidos pelos sensores durante o ensaio.

\section{Componente controlador CAN}

Faz o controle, usando os métodos do objeto SPI1, do $\mathrm{Cl}$ que controla a rede CAN. Possui métodos para efetuar os comandos definidos pela interface SPI do $\mathrm{Cl}$. Possui uma tarefa interna, que só é acessível por outros objetos através de funções de callback fornecidas na inicialização do objeto. Além disso, possui uma rotina de interrupção para reagir aos eventos de término de envio de uma mensagem e recepção de nova mensagem. A rotina de interrupção, para evitar que a latência ou tempo de resposta do sistema fique lenta, apenas sinaliza um semáforo para que a tarefa interna do componente faça a verificação do dispositivo e tome as medidas cabíveis.

\section{Componente atuadores}

Este componente possui várias funções, tais como trava de segurança, controle por estados (controle discreto, como redes de petri), inicialização e configuração de atuadores, controle contínuo no tempo (controlador proporcionalintegral-derivativo) e filtros diversos, como rampas e banda morta para evitar desgaste excessivo dos atuadores.

Por exemplo, uma vez que podem haver danos à bateria se houver uma descarga muito grande, é imperativo que os atuadores sejam desligados caso isto aconteça. Outro problema que pode ocorrer é a perda de comunicação com a estação base. Caso isso ocorra, será acionada uma sequência de emergência.

Quanto ao controle discreto, foi criada uma máquina de estados, sendo que o estado inicial é idle (ocioso), em que todos os atuadores estão desligados. 
Todas as transições ocorrem do estado ocioso ou para o estado ocioso, sem exceção. Foi padronizado dessa forma para que as manobras tivessem melhor repetibilidade. Isso implica que, ao entrar em qualquer um dos modos de manobra, o veículo iniciará uma rotina pré-definida de aceleração, estabelecimento de regime permanente, execução da manobra e posterior desligamento.

No modo de trim é possível ajustar a posição inicial de cada um dos lemes individualmente e configurar os parâmetros das manobras a serem executadas, tais como velocidade, ângulos de leme e de guinada.

No modo prop, são alterados: o tempo de ensaio (Tempo de aquisição, depois do qual o veículo é automaticamente desativado), o tempo de aceleração e estabelecimento do regime permanente em linha reta (Tempo de aceleração), a profundidade padrão a ser buscada, caso esteja em um modo que use manutenção de profundidade por meio de um controlador (AZigZag, ATurn), as inclinações das rampas dos atuadores (velocidade dos lemes e aceleração do motor) e definir o sensor a ser usado para a manobra de zigzag, que pode ser a bússola, a integral do giroscópio ou a saída de um filtro.

No modo manual, as superfícies de controle e o propulsor são controlados diretamente por um joystick.

A Figura 11 mostra o diagrama de estados do AUV Pirajuba.

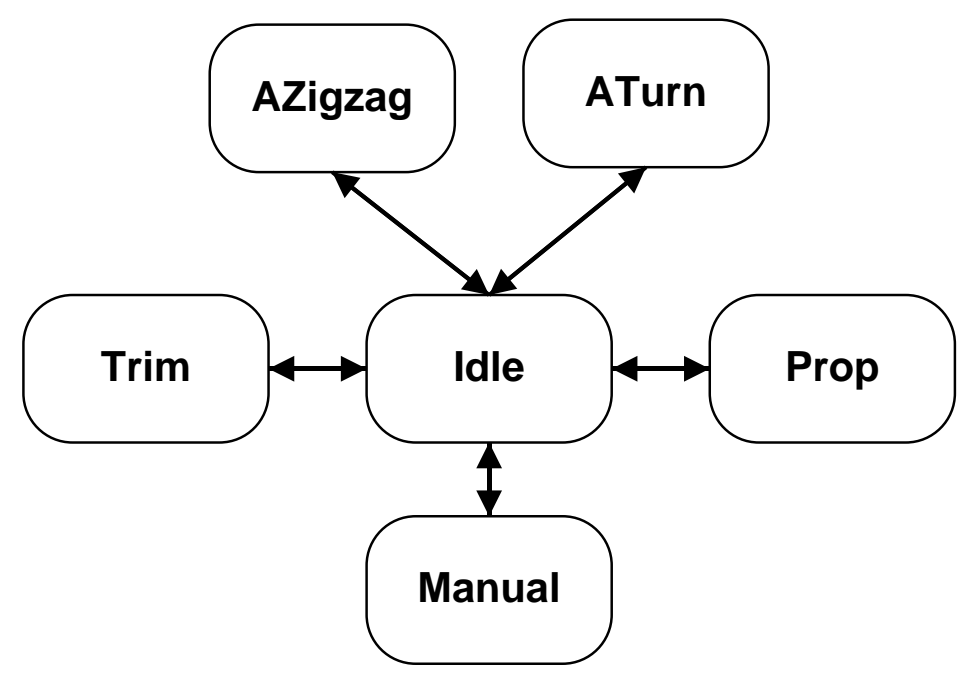

Figura 11 Diagrama de estados do AUV Pirajuba

Este componente possui objetos de baixo nível para traduzir as ordens de um número no sistema do veículo (por exemplo, ângulo de leme em décimos de grau) para um número compatível com a linguagem de máquina, que será o número a ser introduzido nos registradores do microprocessador. 


\section{Componente leituras analógicas}

Este componente engloba os objetos que desempenham várias funções, tais como leitura da carga da bateria, leitura da posição dos atuadores dos lemes, leitura da corrente e velocidade do motor de propulsão e a leitura do giroscópio de fibra ótica. Em geral os objetos que fazem a leitura analógica tem uma tarefa própria e quando a amostragem precisa ser muito elevada, pode ser usado o recurso de callback do BSP para efetuar uma amostra a cada tick do sistema operacional, que no caso, roda a $100 \mathrm{~Hz}$.

\section{Componente sensores digitais}

Esse componente possui objetos que gerenciam os sensores com saída digital, ou seja, que se comunicam através de uma porta serial. Quando o AUV é ligado, os respectivos objetos ativam suas tarefas e fazem a configuração dos sensores, que tipicamente requerem algumas mensagens de inicialização, configuração e comando. Cada objeto, ao receber uma mensagem, checa o checksum para verificar se não há um erro na mensagem. Caso a mensagem esteja correta, é feita a decodificação para o padrão binário. Depois disso, os dados recebidos são enviados pelo barramento CAN via sharedMemory.

Outra atribuição deste componente é a comunicação via link de rádio, que também utiliza uma porta serial RS232.

\section{IHM - interface com usuário}

Usando uma biblioteca para o Simulink de RS232, foi desenvolvido um software com as seguintes funções: leitura dos dados enviados pelo software embarcado; aquisição de comandos de um joystick típico de simuladores de voo; arquivamento automático de dados relevantes; e apresentação, em um ambiente de realidade virtual, da atitude do veículo, dos ângulos de leme e de outros dados julgados relevantes para a operação do veículo.

Vale ressaltar que este ambiente de realidade virtual pode ser visualizado em navegadores padrão de internet, o que possibilita desde já a visualização de dados em vários computadores ligados em uma rede ethernet.

\section{Objeto datalog}

Esse objeto possui uma tarefa interna própria e tem como objetivo criar uma cópia de segurança dos dados gerados no ensaio. Recupera todos os dados do objeto sharedMemory, gera uma string no padrão ASCII e, ao acumular mais do que 512 bytes, armazena na memória permanente que é gerenciada pelo objeto FAT, 
que por sua vez usa o objeto SPI0. Também funciona como uma máquina de estados. Seus estados são 3 (Figura 12): Ocioso, quando armazena uma leitura do sistema por segundo; Desligado, quando fecha o arquivo no cartão de memória e para toda atividade para evitar danos no desligamento; e manobrando, quando armazena a $10 \mathrm{~Hz}$ todos os dados.

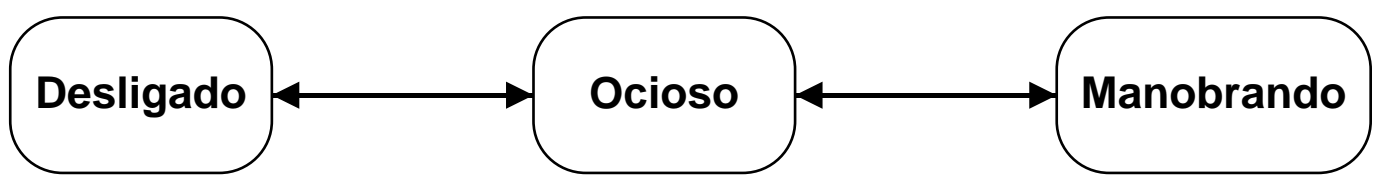

Figura 12 Diagrama de estados do objeto Datalog

\subsubsection{Camada de comunicação (memória compartilhada)}

Essa camada possui apenas uma classe de objetos (sharedMemory) e providencia, para todos os objetos de cada nó, todos os dados necessários, vindos pela rede ou não. Funciona de maneira similar ao objeto MOOS-DB visto em [40], usando a técnica de publicar e assinar pares de dados (identificador e dado). Possui uma instância em cada nó da rede.

Ao receber um dado novo, que é constituído por um identificador e oito bytes de dados binários, ela armazena localmente, anota o horário e retransmite para todos os nós da rede e notifica outros usuários que tenham pedido essa informação por meio de um semáforo. Ao receber uma mensagem CAN, ela registra o dado novo, anota o horário em ticks do sistema operacional, e notifica todos os usuários que pediram essa informação.

Essa arquitetura aproveita o caráter omnidirecional da transmissão da mensagem CAN. Quando um nó transmite uma mensagem, todos os outros recebem. Tentar empregar um protocolo baseado em comunicação ponto a ponto entre dois nós, tal como empregado em [33] seria muito ineficiente em uma rede CAN.

Assim, para cada processo que precisa de comunicação com outros processos, a localização física (o nó onde ele roda) não é importante, pois a classe sharedMemory torna a comunicação transparente para todos os outros processos. É como se todos os processos estivessem rodando em um único processador. A única limitação é o acesso físico a sensores e atuadores. 
Essa infraestrutura permite que um objeto de nível superior possa ser facilmente transferido de um nó para outro sem causar complicações adicionais, pois ela faz com que todas as informações estejam disponíveis igualmente em todos os nós, exceto quando esse objeto lida com recursos que são intrínsecos a um determinado nó.

\subsubsection{Camada de gerenciamento da missão}

Nesta camada ficam os componentes relacionados à missão do AUV, tais como guiagem, navegação, planejamento da trajetória e comportamentos diversos. Para o escopo deste trabalho, apenas um objeto foi desenvolvido, descrito a seguir.

\section{Componente controle autônomo de manobras}

Esse objeto possui uma tarefa interna que fica desativada esperando que o sistema entre em algum estado de manobra. Possui ainda atributos como o leme padrão, a guinada padrão, velocidade padrão, tempo de aquisição e tempo de aceleração que são modificados pelos comandos recebidos da estação base. Quando ocorre a transição para um estado de manobra, que é necessariamente a partir do estado idle, com todos os atuadores desligados, a tarefa aciona os lemes com os respectivos ângulos de trim, o que deverá ser o zero do ponto de vista mecânico, aciona o motor, que deverá a ser acelerado de acordo com a aceleração pré-estabelecida, e esperará a que o veículo atinja o regime permanente. Após esse tempo, será iniciada a manobra definida, que pode ser a manobra AZigZag ou ATurn. Durante a manobra é usado um algoritmo de controle para manter a profundidade desejada em malha fechada a partir das leituras do sensor de pressão.

\subsection{Comparação com arquiteturas Notáveis}

Nesta seção, são feitas comparações da presente arquitetura de controle com as arquiteturas vistas na seção 2.3, em termos da rede de dados adotada, custos, consumo de energia, continuidade do desenvolvimento, facilidade de desenvolvimento, segurança e disponibilidade, expansibilidade e flexibilidade. Tais características são requisitos deste trabalho e servem de parâmetros avaliação comparativa com outros trabalhos no estado da arte.

\subsubsection{CAN vs Ethernet}

Normalmente, a Ethernet tem sido a escolha mais popular, apesar da alternativa CAN e RS-232 ser encontrada em algumas implementações de AUV. No entanto, um certo número de autores relatam inconvenientes quando se utiliza a 
Ethernet, que estão relacionados com a colisão de mensagens e o espaço necessário para o hub, e cabos, especialmente quando a redundância deve ser incluída no sistema[2][19][47]. Levando-se em conta aspectos como custo, disponibilidade, volume, cabeamento, o consumo de energia, previsibilidade e largura de banda, com freqüência o CAN pode se tornar uma escolha melhor do que Ethernet [12]. Enquanto Ethernet utiliza uma velocidade alta (20MHz, pelo menos), o barramento CAN utiliza uma velocidade de apenas $1 \mathrm{MHz}$. Isso permite uma cablagem simples e mais robustos (8 fios de Ethernet contra 2 para CAN). Além disso, Ethernet requer uma topologia em estrela, onde um hub (que precisa de energia) está no centro, requerendo mais cabos do que uma topologia de barramento CAN. Embora os dispositivos com Ethernet estejam se tornando mais baratos ao longo do tempo, eles ainda são mais caros do que os dispositivos CAN. Finalmente, o protocolo CAN é poderoso o suficiente para as funções básicas (controle, navegação, comunicação e sensoriamento básicos) de uma arquitetura de controle de um AUV de baixo a médio de custo.

Evidentemente, para versões futuras que requeiram a integração de sensores com alta taxa de transmissão de dados, tais como câmeras de vídeo, o uso de uma rede ethernet sem qualquer requisito de segurança pode ser necessário. A tecnologia mais promissora seria uma rede Wi-Fi por não precisar de cabos e hub switches. Dado o espaço reduzido dentro do AUV, tal rede seria muito confiável.

\subsubsection{Custos}

Os custos do hardware adotado são bastante baixos, em comparação com arquiteturas baseadas no padrão Ethernet, principalmente, porque componentes empregados na indústria automotiva são utilizados (ARM7 microprocessadores e chips CAN). Além disso, como um número limitado de tipos de PCBs polivalentes (placas de circuito impresso), que podem ser empilhados em qualquer nó, foram desenvolvidos, com um pequeno número de peças, é possível proporcionar os componentes para um novo nó ou de substituição dos PCB defeituosos. Assim, usando componentes robustos, confiáveis e baratos que são todos disponíveis no mercado local e uma arquitetura modular, espera-se que os danos devido a erro humano (a maioria da força de trabalho é constituída por iniciantes) ficam restritos e não criam grandes atrasos. Outro fator que deve reduzir custos em longo prazo é a análise das tecnologias de permanência no mercado. Se apenas tecnologias 
amplamente utilizadas são empregadas, a probabilidade de descontinuação do produto é muito pequena. Isso significa menos retrabalho devido a problemas de obsolescência ou despesas logísticas. Os custos de desenvolvimento de software deve ser bastante baixo em termos de ferramentas de desenvolvimento, pois apenas ferramentas livres, como o Eclipse CDT, o GNU compilador GCC e sistema operacional uC-OSII estão sendo utilizados. Embora não seja possível dizer que estas são ferramentas de alta produtividade, são facilmente compreendidas por alunos de graduação e engenheiros, requerendo pouco tempo para treinar pessoas. Além disso, a adoção de apenas uma tecnologia e uma ferramenta para todo o sistema reduz os esforços de treinamento de pessoal.

Pode-se afirmar que, dadas as características do mercado local, a arquitetura proposta possui um custo mais baixo do que as arquiteturas notáveis estudadas na revisão bibliográfica, que utilizam computadores de performance mais elevada.

\subsubsection{Consumo de Energia}

Microprocessadores ARM são conhecidos por suas características de baixo consumo de energia. Os microprocessadores ARM7 LPC2148 NXP demandam em torno de 0,4 W, tendo um consumo cerca de duas ordens de magnitude menor do que o consumo de um processador x86. Para um pequeno AUV alimentado a bateria, esta redução das necessidades de energia significa uma melhoria na autonomia e uma redução da temperatura interna uma vez que quase todo o poder utilizado por um processador é convertida em calor. A redução da temperatura de trabalho também tem efeitos benéficos na confiabilidade do hardware, conforme visto no item 4.5.3.

Pode-se dizer que, nesse quesito, há um empate com a arquitetura DSAAV, que também emprega $\mathrm{ARM}$ e um aperfeiçoamento em relação à arquitetura backseat.

\subsubsection{Continuidade do desenvolvimento}

Do ponto de vista de desenvolvimento de software, para um ambiente universitário, onde a maior parte da força de trabalho é baseada em estudantes de graduação ou em curso de mestrado, a solução não deve exigir cursos longos ou requerer conhecimentos além do básico de engenharia ensinado na graduação. Foi decidido empregar uma seleção de ferramentas baseadas na linguagem $\mathrm{C}$, facilmente entendido por estudantes de graduação. Desta forma, reduz-se a 
dependência do projeto de profissionais com formação especializada para a atualização e manutenção de código.

No entanto, todo o desenvolvimento segue a programação estruturada e orientada a objetos. Uma vez que a linguagem $C$ é amplamente conhecida e utilizada por amadores, juntamente com o compilador GNU GCC e é aplicada a processadores ARM7, é fácil encontrar um vasto material de treinamento na internet, que é de fácil entendimento. $\mathrm{O}$ uso de um pequeno sistema operacional em $\mathrm{C}$ com o código fonte disponível não apenas é mais fácil usar, mas também possibilita entender o que é exatamente um sistema operacional, sendo uma boa ferramenta pedagógica. Adicionalmente, sugere-se o treinamento de programadores no desenvolvimento de software relacionado à segurança do AUV, de forma a se manter a conformidade com padrões de codificação e procedimentos de documentação, o que assegura a qualidade necessária.

Para o desenvolvimento de hardware, alguma formação em design de layout de PCB, que pode ser baseada em algumas recomendações de fornecedores [49]. O número reduzido de componentes, também reduz o tempo para estudar datasheets, a fim de criar novos módulos. Concluindo, espera-se alcançar um desenvolvimento estável e contínuo, sem dependência de indivíduos e com os mais baixos requisitos de formação possível. Isso geralmente não é um objetivo para muitos AUVs, porque as empresas podem dispor de pessoas por um longo tempo, então ferramentas mais complexas, mas com maior produtividade são as preferidas. Por outro lado, muitos AUVs desenvolvidos em universidades têm uma vida útil curta, sendo utilizada apenas como uma ferramenta para explorar um conjunto de temas acadêmicos de investigação. Mas, mesmo para as universidades, há um ganho se algumas técnicas de gestão são aplicadas para garantir uma sinergia positiva entre os diversos atores.

Neste quesito, aparentemente existe uma equivalência com as arquiteturas DSAAV e backseat e uma melhoria em relação à arquitetura anterior do AUV Pirajuba.

\subsubsection{Facilidade de desenvolvimento}

Uma vez que programadores freqüentemente disponibilizam os seus códigos fontes na internet, muitos recursos de software podem ser adaptados de outros projetos encontrados na internet, como ocorreu com o sistema de arquivos FAT e o driver CAN. Isso acelera o desenvolvimento, se comparada com ferramentas que 
não são bem conhecidas. Como a filosofia é desenvolver para reutilização, além da primeira versão, que deve ser desenvolvida com cuidado, para todas as outras versões será necessário um pequeno esforço. As ferramentas não são muito eficientes, por exemplo, não há geração automática de código, mas são fáceis de aprender. Dada a alta rotatividade de pessoal, acredita-se que, para este caso particular, o tempo de desenvolvimento é a menor possível.

Neste ponto, existe também uma certa equivalência com as arquiteturas DSAAV e backseat, que empregam ferramentas abertas.

\subsubsection{Segurança / disponibilidade}

Embora a linguagem $C$ não foi desenvolvida originalmente para aplicações de segurança, hoje em dia, é uma ferramenta bem conhecida e seus problemas estão bem delimitados. Através da aplicação de padrões de codificação (Neutrino e MISRA C) e boas práticas (separação de funções normais e de segurança, interfaces seguras e reutilização) espera-se atingir um nível razoável de segurança e confiabilidade do ponto de vista do software. Em aspectos de hardware, a robustez e simplicidade de componentes deve fornecer um bom nível de confiabilidade. A baixa emissão térmica e baixa temperatura de funcionamento, juntamente com invólucros à prova d'água, deve reduzir a corrosão nos pinos e faixas de redução de taxa de falha. A arquitectura altamente modular deve atingir um nível de elevada disponibilidade devido à redução do tempo de reparo. Em comparação com a média de outras arquiteturas, essas escolhas parecem levar a um melhor índice de custo/benefício.

\subsubsection{Expansibilidade}

O número de nós possível é praticamente ilimitado para um pequeno AUV, supondo que cada nó recebe e envia um pequeno número de identificações. Em conformidade com a especificação CAN, cada ID pode ter 11 bits, resultando em 2.048 diferentes possibilidades. É fácil de atualizar para CAN2.0 padrão, que pode permitir que mais de 4 bilhões de IDs de diferentes mensagens. Por haver uma pequena necessidade de cabeamento, não é difícil adicionar redundâncias. Há uma limitação da largura de banda (1Mbits / s) o que limita o tipo de sensor que pode ser ligado na rede de segurança. No entanto, a maioria dos sensores não precisam mais de 8 bytes a $10 \mathrm{~Hz}$, necessitando de menos de $800 \mathrm{bits} / \mathrm{s}$ por sensor ou atuador. Isso significa que a rede CAN pode empregar cerca de mil sensores ou atuadores assegurando resposta temporal para mensagens prioritárias, o que não pode ser 
assegurada por uma rede Ethernet. A principal desvantagem é que não há largura de banda suficiente para incorporar transmissão de imagem na rede de segurança. No entanto, devido à separação de funções normais e de segurança, e sendo a transmissão e processamento de imagems uma função normal, ela não seria incorporada no barramento de dados de segurança.

\subsubsection{Flexibilidade}

A flexibilidade do hardware atinge um nível elevado, comparável à DSAAV [5]. Através da utilização de subsistemas e interfaces padronizadas, é fácil montar um novo nó para uma função nova e incorporá-la no sistema. O software também tem um alto nível de flexibilidade uma vez que o nível médio (e abaixo) de funções não são afetados pela inclusão novas funções de alto nível. Além disso, o nó no qual uma dada função é executada é transparente para as outras funções, sendo limitadas apenas pelos periféricos. Isso permite a distribuição de poder de processamento pelos nós. Um inconveniente, se comparado com DSAAV, é a falta de recursos de reprogramação sem acesso físico aos nós. Embora não haja nenhuma necessidade de abrir o invólucro à prova de água, há necessidade de abertura do casco AUV resistente. No entanto, de um ponto de vista da segurança, a impossibilidade de mudar a firmware segurança no campo pode ser visto como um aspecto positivo devido a evitar erros humanos.

Para as funções normais, que podem ter uma conexão Ethernet sem fio, recursos de reprogramação on-line podem ser adicionados nos avanços futuros.

\subsection{Considerações finais}

Neste capítulo foi apresentado o processo decisório durante a implementação da arquitetura de controle proposta por este trabalho. As decisões foram tomadas à luz de tópicos da engenharia de sistemas e espera-se gerenciar a complexidade de um sistema multidisciplinar sem fazer exigências que não sejam razoáveis a cada participante e com razoáveis esforços de produção de uma nova versão do AUV. 


\section{RESULTADOS}

Este capítulo apresenta os resultados efetivamente obtidos pela arquitetura desenvolvida e faz a comparação com os requisitos mencionados na seção 4.3.

\subsection{Atendimento aos requisitos}

Modularidade: A modularidade está presente em vários níveis. O hardware empregado dentro de cada nó é modular e com interfaces padronizadas (barramento de 64 pinos e conectores MIKE). A arquitetura de controle é modular, sendo que cada nó tem interfaces padronizadas de rede de dados (CAN) e alimentação elétrica $(5 \mathrm{Vdc})$. O software foi desenvolvido usando um sistema operacional e empregando uma filosofia orientada a objetos, apesar de usar uma linguagem que não é orientada a objetos. Isto permite o reuso e fácil adaptação de elementos já criados anteriormente para novas aplicações.

Robustez: Os componentes eletrônicos empregados em sua maioria usam tensões de 0 a $5 \mathrm{~V}$, o que os confere certa resistência ao manuseio. Os conectores dentro de cada nó foram eliminados, reduzindo a quantidade de pontos de fragilidade. O conector de 64 pinos é bastante robusto e fácil de usar. Os conectores MIKE são polarizados e robustos ao manuseio, o que evita a conexão errônea.

Facilidade de desenvolvimento: Foi empregada a linguagem $C$, que é ensinada em universidades, ferramentas gratuitas de amplo conhecimento público, como o compilador GNU e o ECLIPSE e referências técnicas compreensíveis para o pessoal. Juntamente com a modularidade de hardware e de software, fica simples e fácil para alunos de graduação criar novos módulos e funcionalidades.

Baixo custo: Foram usados apenas circuitos integrados baratos e disponíveis no País, como o LPC2148, MCP2515 e MCP2551. Tais circuitos são empregados na indústria automobilística e são produzidos em larga escala, razão pela qual não é esperada uma súbita descontinuação de sua produção no médio prazo.

Baixo consumo energético: comparado com a arquitetura anterior, houve uma significativa redução do consumo energético, atingindo cerca de $1,2 \mathrm{~W}$ no somatório dos ARM7, contra cerca de 30W do PC-104. Além disso, foi eliminado o consumo elétrico do hub switch. Um bônus adicional foi a eliminação do aquecimento dentro do AUV.

Pequeno volume: A quantidade de cabos de comunicação foi bastante reduzida uma vez que a rede CAN usa um barramento único e a rede Ethernet 
emprega uma estrela com o hub switch no centro. Houve alguma redução do volume total da arquitetura de controle, mas a grande vantagem está no fato de que as caixas são mais fáceis de arranjar dentro do AUV, se comparadas com o PC-104.

Baixo tempo de desenvolvimento: Vários fatores contribuem para isso: o tempo de treinamento necessário para que um aluno de graduação comece a trabalhar efetivamente é pequeno; a modularidade permite que vários subsistemas sejam desenvolvidos ao mesmo tempo por diversos alunos; a padronização do software e do hardware facilita o reuso; os equipamentos são robustos e simples, reduzindo a quantidade de contratempos; peças de reposição podem ser compradas em grande quantidade e mantidas em estoque a um baixo custo ou podem ser compradas diretamente no comércio local. Logo, adicionar novas funcionalidades ou adaptar as funcionalidades existentes para uma nova aplicação do AUV requer pouco tempo e esforço de programação.

Alta segurança e disponibilidade: foram tomadas precauções especiais quanto ao tratamento dos componentes eletrônicos, que foram colocados dentro de caixas estanques, protegendo as placas de circuito impresso da maresia. Quanto ao software, a adoção de padrões de codificação, aliada a funções de proteção do AUV, relacionadas à bateria e ao controle de lemes e propulsão, permite dizer que os riscos que podem ser ocasionados devido a erros de software são baixos. Outro aspecto é a segregação funcional, que separa as funções relacionadas à sobrevivência do AUV das funções mais sofisticadas tais como algoritmos de navegação, que não podem acessar diretamente o barramento CAN. Assim, dado o processo criado para desenvolvimento de software relacionado à segurança e posterior tempo de uso, haverá uma boa confiança de que as funções relacionadas à sobrevivência do AUV são seguras e que erros nas funções posteriormente adicionadas não comprometerão a segurança do AUV.

Expansibilidade: O barramento CAN pode incorporar até 1024 nós, o que pode ser considerado um potencial virtualmente ilimitado de expansão. A largura de banda usada ainda é muito pequena, havendo espaço para muito mais sensores e atuadores sem qualquer degradação de desempenho. Evidentemente, sensores que exijam alta largura de banda, tais como câmeras e sonares side-scan precisarão de outra rede de dados não relacionada à segurança.

Flexibilidade: Essa arquitetura foi aplicada a um AUV, mas poderia ser adaptada facilmente a outras aplicações. Ainda que alterações sejam feitas em 
aspectos pontuais, como tecnologias de rede de dados, existe um conhecimento sobre o domínio que pode ser reaproveitado, como a arquitetura de software, as placas de circuito impresso e a filosofia de desenvolvimento, que pode ser aplicada a qualquer projeto de automação de um sistema complexo. Essa filosofia consiste em estabelecer a modularidade, padronizar interfaces, empregar ferramentas conhecidas, projetar para reuso e acumular, de forma útil e prática, o conhecimento produzido por cada aluno no laboratório.

Continuidade do desenvolvimento: Os outros alunos puderam efetuar alterações e adicionar funcionalidades ao sistema de controle. Maiores detalhes quanto à continuidade serão dados na seção 5.4 .

Quanto às tarefas a serem efetuadas por essa versão inicial de arquitetura de controle, elas foram demonstradas (no sentido de demonstração da referência [45]) com sucesso em testes de validação na piscina. Maiores detalhes serão fornecidos na seção 5.3. Quanto às etapas de desenvolvimento, pode-se dizer que foram cumpridas dentro do prazo esperado e o funcionamento não apresentou fatos inesperados.

\subsection{Desempenho de hardware}

Por enquanto, o uso máximo de memória de um nó foi 54kBytes de ROM (de 512kBytes disponíveis) e 11kBytes de RAM (de 40kBytes disponíveis). A capacidade de processamento máxima requerida foi inferior a 3\%. A largura de banda utilizada no barramento CAN chegou 1,6\% da largura de banda total. Estes números mostram que as escolhas de hardware presentes permitem futuras atualizações, mesmo sendo composto por componentes de baixo custo.

\subsection{Validação em piscina do veículo}

A funcionalidade do AUV foi verificada durante os testes em uma piscina. A estação de base na superfície poderia iniciar e interromper manobras préprogramadas através de comandos transmitidos através de um link de rádio com um nó de processamento no vaso principal. Tendo em conta o comprimento limitado da piscina, bem como a comparação com os ensaios com um protótipo no tanque de reboque, manobras da piscina foram realizados a uma velocidade de $1 \mathrm{~m} / \mathrm{s}$. Um controlador de profundidade foi implementado usando um algoritmo de alocação de pólos. A lei de controle leva em conta o erro de profundidade, o ângulo de inclinação e a taxa de variação do ângulo de inclinação. A profundidade foi mantida em torno 
de um valor constante de $0,8 \mathrm{~m}$ durante as manobras em ziguezague em relação ao plano horizontal.

Foi escolhida uma das manobras para apresentar neste trabalho, sendo todas as figuras referentes a um mesmo ensaio. Recapitulando as tarefas a serem executadas:

1. Controle da propulsão: fica evidente na Figura 17, que mostra a aceleração do eixo propulsor em forma de rampa, manutenção da rotação durante a manobra e seu desligamento;

2. Atuação das superfícies de controle: mostrada na Figura 15, que mostra a medida da posição dos servos e o efeito na orientação do AUV;

3. Aquisição da tensão nas baterias, corrente no servomotor de propulsão, profundidade, sinais da IMU e Bússola: Foram escolhidos para apresentação os sinais da IMU (Figura 13) e da bússola (Figura 14 e Figura 16)

4. Processamento de dados que permita a execução de manobras simples - manobra de giro e zig-zag: a Figura 15 mostra a manobra de zig-zag de $5^{\circ}$ de leme com guinadas de $5^{\circ}$;

5. Armazenamento de dados: todos os dados mostrados nas figuras deste capítulo foram retirados do cartão de memória, o que demonstra (no sentido de demonstração da referência [45]) essa funcionalidade; e

6. Comunicação com uma estação-base: o comando para o início da manobra e a configuração para a manobra são executados a partir da estação base. Apesar de a estação base receber todos os dados que ficam armazenados no cartão de memória, verificou-se que a transmissão e a interpretação por parte do Simulink não eram totalmente confiáveis. Assim sendo, a comunicação com a estação base se mostrou satisfatória para enviar comandos, mas não para download dos dados obtidos.

Como pode ser visto na Figura 13, durante o estado de repouso a integral da velocidade angular deriva lentamente, apesar de visualmente parecer que o ruído é bem pequeno na medida da velocidade angular. 


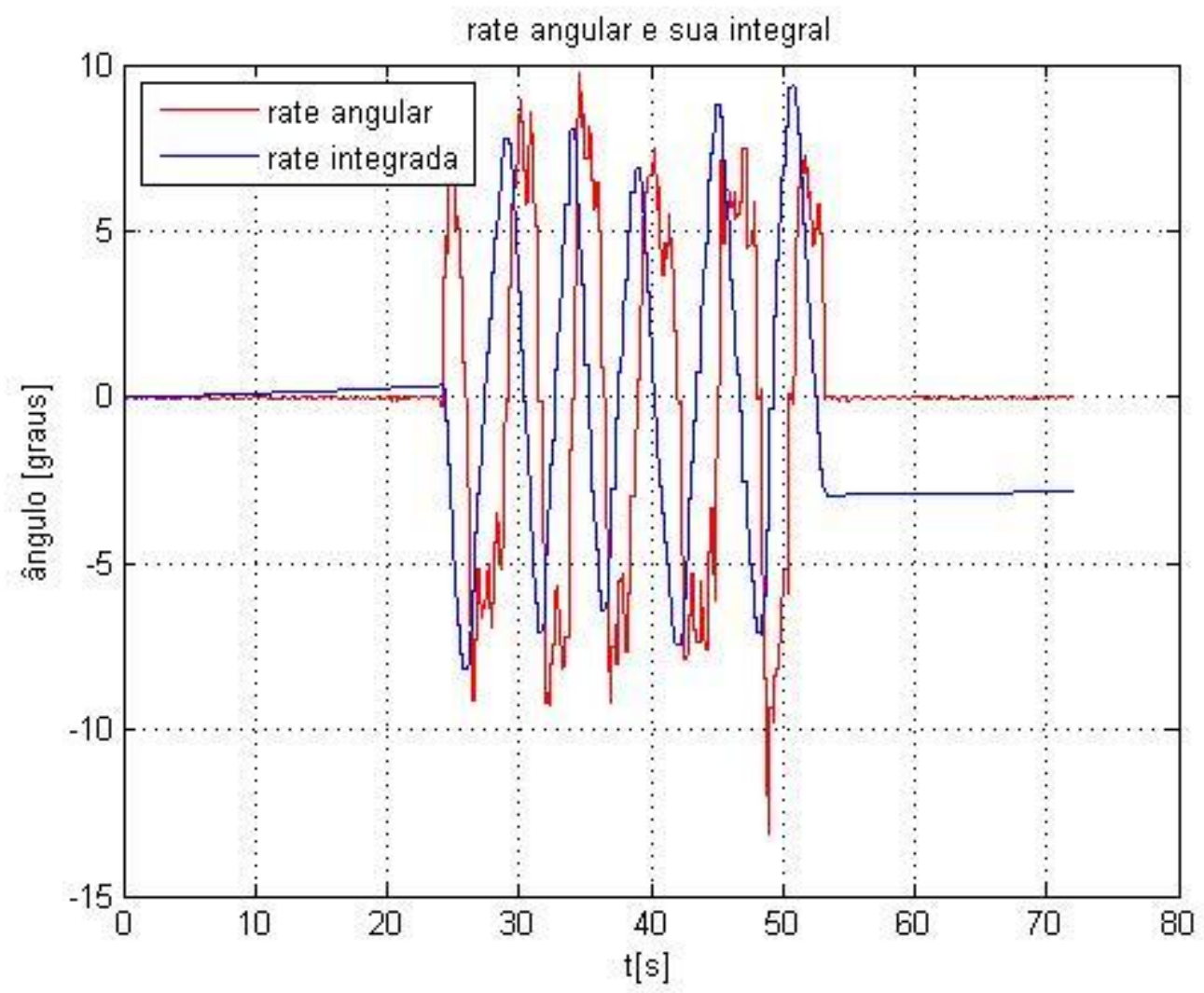

Figura 13 Leitura do giroscópio e sua integral

Nota-se, pela Figura 14, que o ângulo de pitch varia bem pouco neste caso, pois o movimento se dá por meio de deslizamento sobre um plano. Por outro lado, houve bastante interferência no ângulo de roll. 


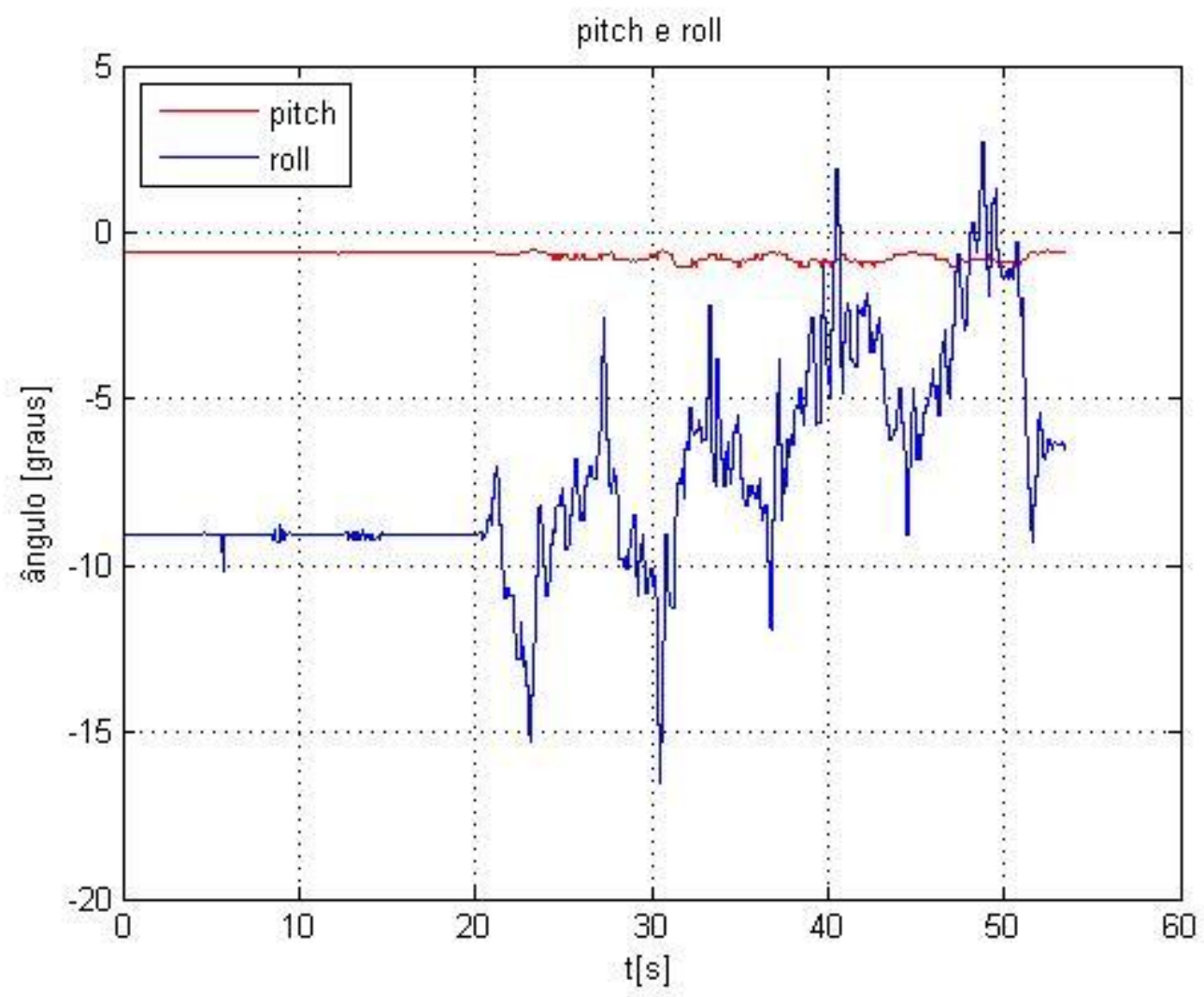

Figura 14 Ângulos de roll e pitch medidos pelo inclinômetro da bússola

A Figura 15 faz uma comparação do ângulo de leme e do yaw, e exibe algum ruído na medição da deflexão dos lemes. Note que a inversão dos lemes se dá no ponto quase exato em que o yaw passa por $+/-5^{\circ}$. 


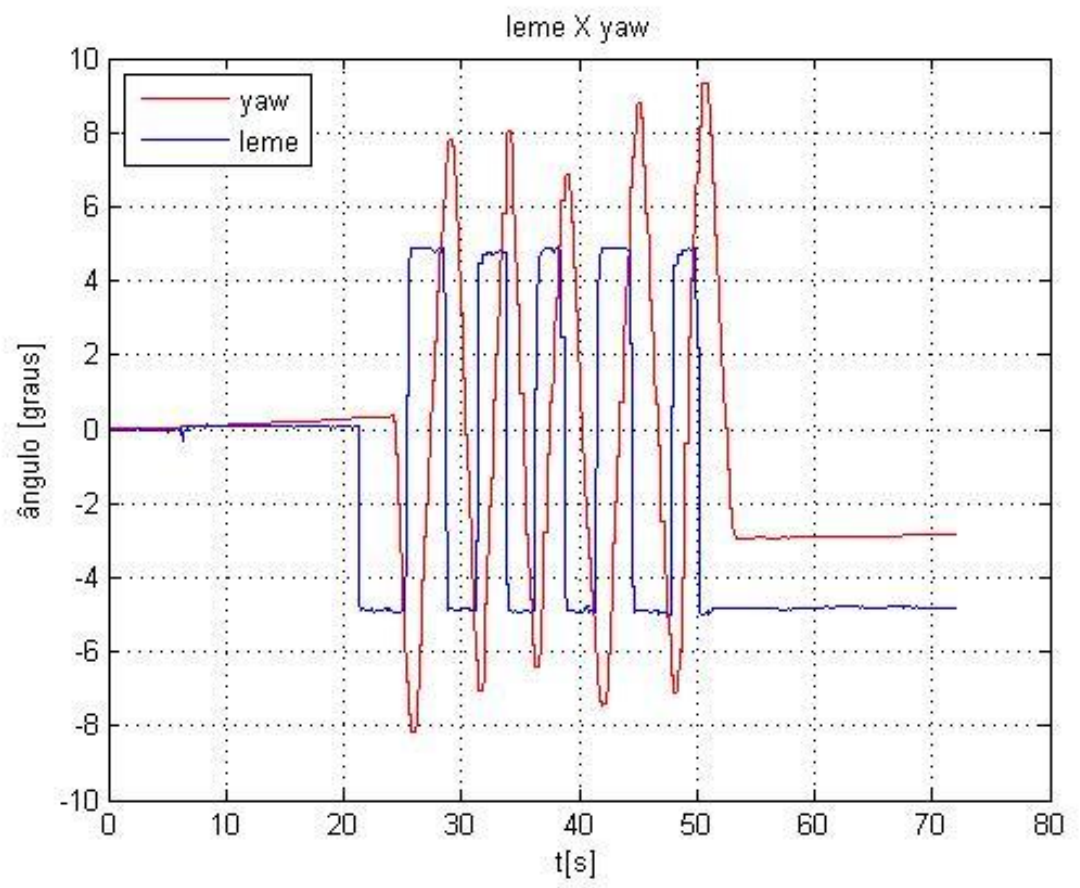

Figura 15 Comparação do ângulo de leme e do yaw

Observa-se, na Figura 16, que, para um dos lados, a saída da bússola acompanha melhor a integral do giroscópio do que para outro. Isso se deve a uma fonte local de distúrbio magnético, a saber, massas de materiais ferromagnéticos presentes na piscina. Pode-se ver que as medições de campo magnético ficam bastante comprometidas. 


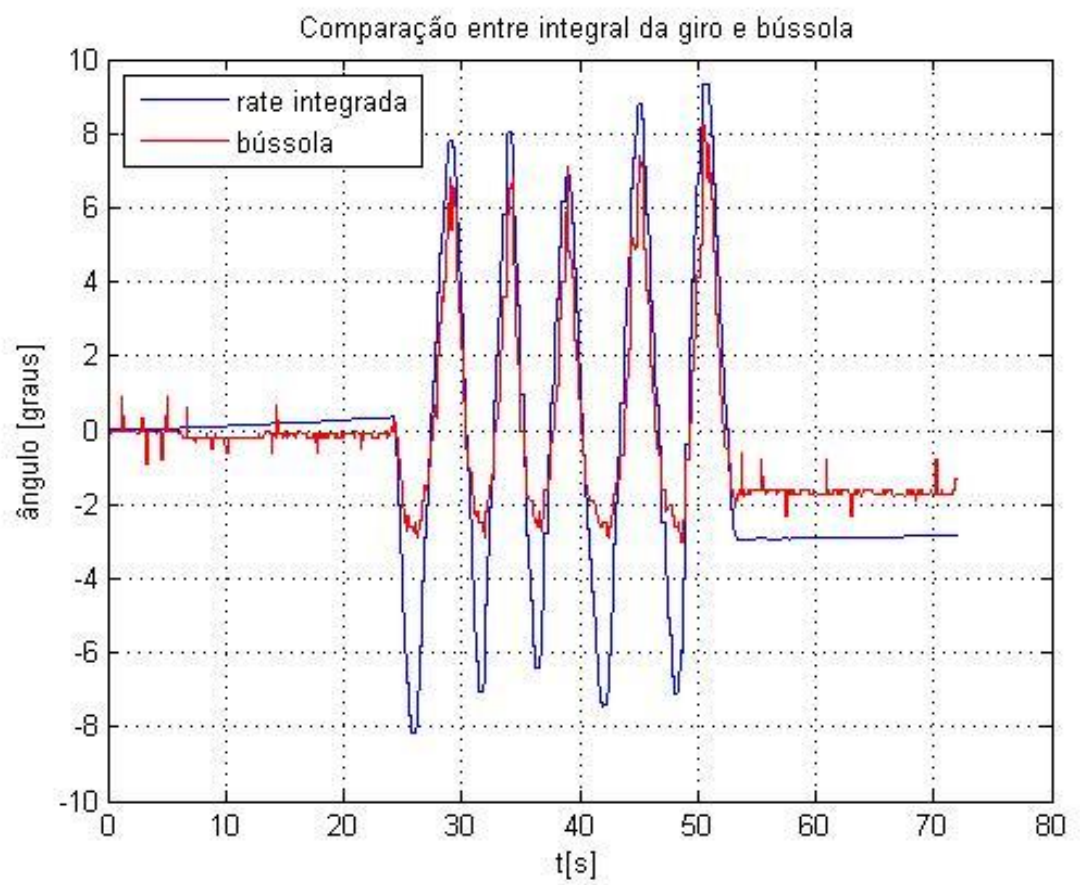

Figura 16 Comparação da saída da bússola e da integral da saída do giroscópio

A Figura 17 mostra a leitura da rotação do eixo do propulsor. Na leitura da rotação do eixo do motor observa-se um pequeno ruído e alguma histerese. 


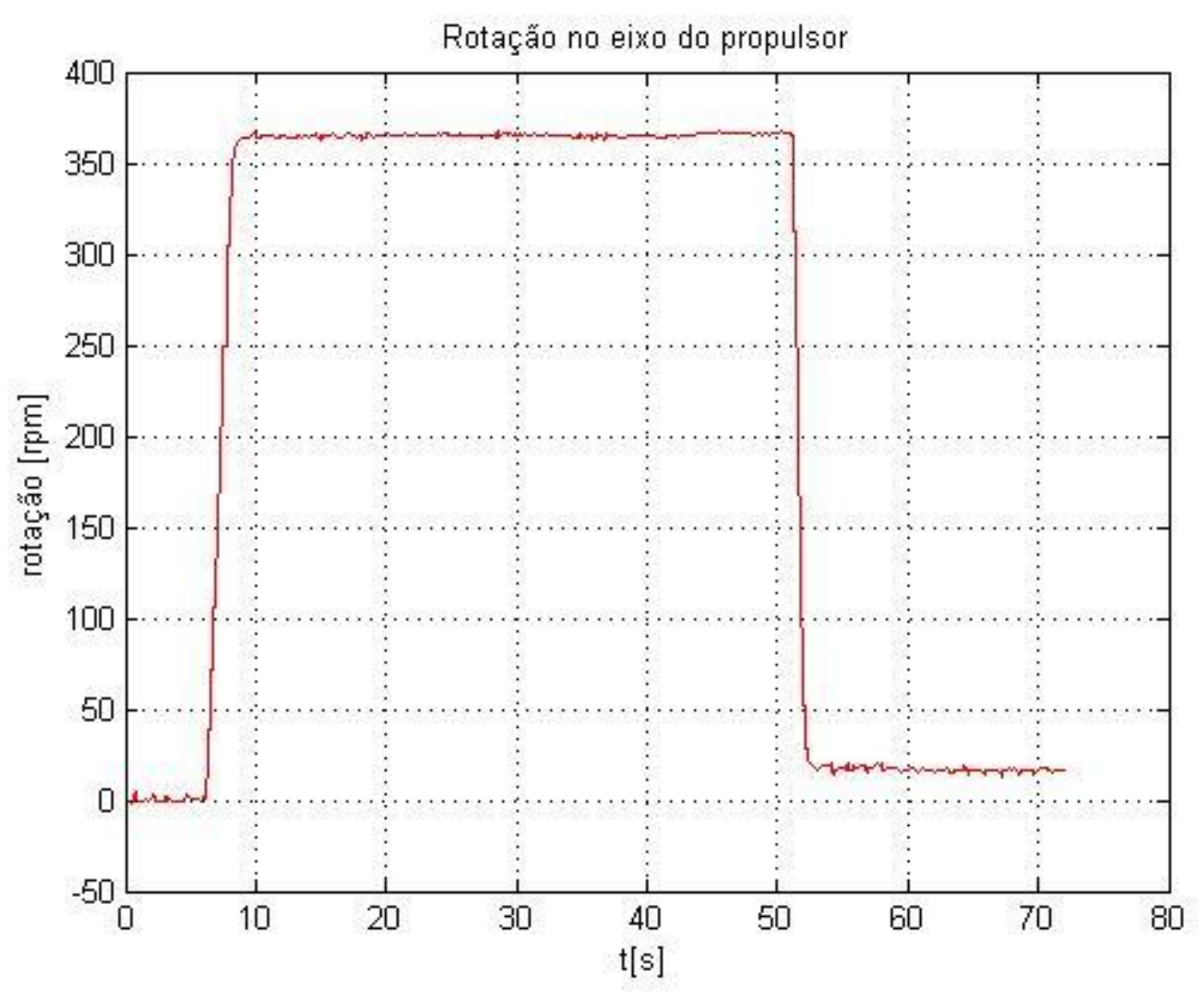

Figura 17 Leitura da rotação do eixo do motor

\subsection{Continuidade do desenvolvimento}

Esse trabalho foi desenvolvido de 2008 a 2010, parte ainda como iniciação científica no LVNT. A arquitetura apresentada até agora foi entregue em 2010. Por razões pessoais, o autor deixou de trabalhar no LVNT de 2010 a 2012. Nesse período, outros alunos continuaram aprimorando o resultado deste trabalho, introduzindo novas funcionalidades e substituindo algumas que se tornaram obsoletas.

A principal validação desse trabalho foi a continuidade do desenvolvimento por outros alunos do LVNT. A versão de 2013 da arquitetura de controle apresenta uma série de novas funcionalidades, deixando o veículo bem mais adaptado à sua função de executar ensaios livres. Tais alterações foram realizadas por Rodrigo Telles da Silva Vale e Lucas Machado de Oliveira seguindo a filosofia adotada neste trabalho. Entre as novas funcionalidades estão:

- Comando de início de manobra por meio de uma torção no leme; 
- Eliminação do cordão umbilical, havendo troca de informações com a estação base somente na superfície;

- Estação base apenas configura o tipo de manobra a ser executada e descarrega os dados obtidos no ensaio (o veículo opera de maneira realmente autônoma agora);

- Novos tipos de controle de profundidade e de rumo foram implementados;

- Novas manobras foram adicionadas;

- Novos sensores foram incorporados;

- A manobra de zigzag foi aperfeiçoada, incorporando maior número de passos.

A arquitetura de software de 2013 pode ser vista na Figura 18. Pode-se notar que não houve mudanças estruturais significativas.

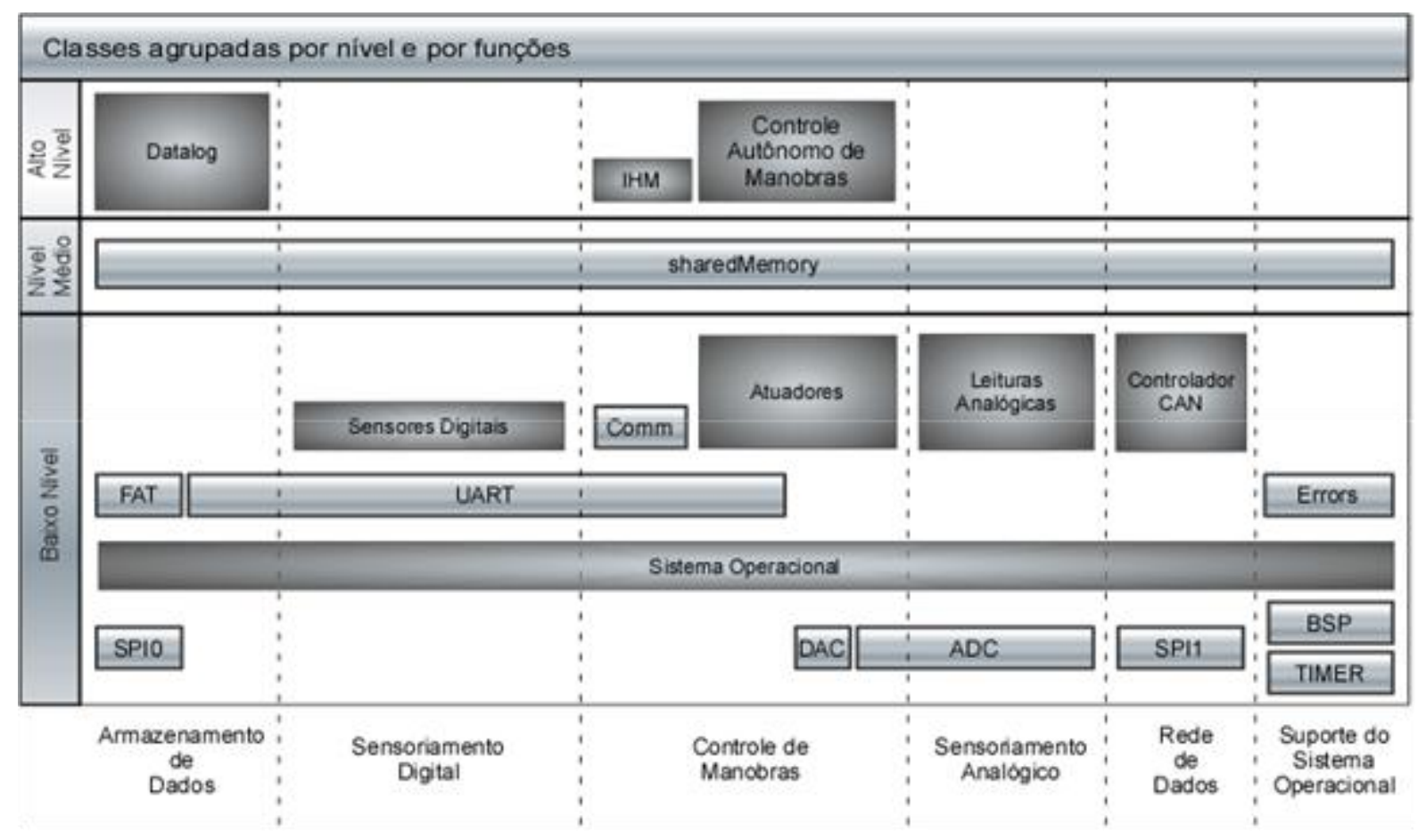

Figura 18 Novo diagrama da arquitetura de software

Após ganhar confiança na arquitetura de controle em testes na piscina, foram executados testes no mar nos quais a eficácia da arquitetura de controle, com os novos recursos descritos anteriormente, foi comprovada. A nova manobra de zigzag incorpora um período de movimentação de leme para reconhecer o comando de início da manobra, que é uma torção manual do leme. 
No instante $t=25 \mathrm{~s}$, o motor de propulsão é acionado e o leme horizontal conduz o veículo à profundidade desejada, como se pode ver na Figura 19. Após estabilizar na profundidade desejada, no instante $\mathrm{t}=63 \mathrm{~s}$, os lemes são deixados a meio para permitir a entrada em regime permanente. Ocorre um desvio da profundidade de referência. No instante $t=85 \mathrm{~s}$, inicia-se 0 ensaio de zigzag e 0 controle de profundidade é reativado. A Figura 19 mostra que o controle de profundidade é eficaz em retomar e manter a profundidade desejada. No instante $\mathrm{t}=125 \mathrm{~s}$ o ensaio é terminado.

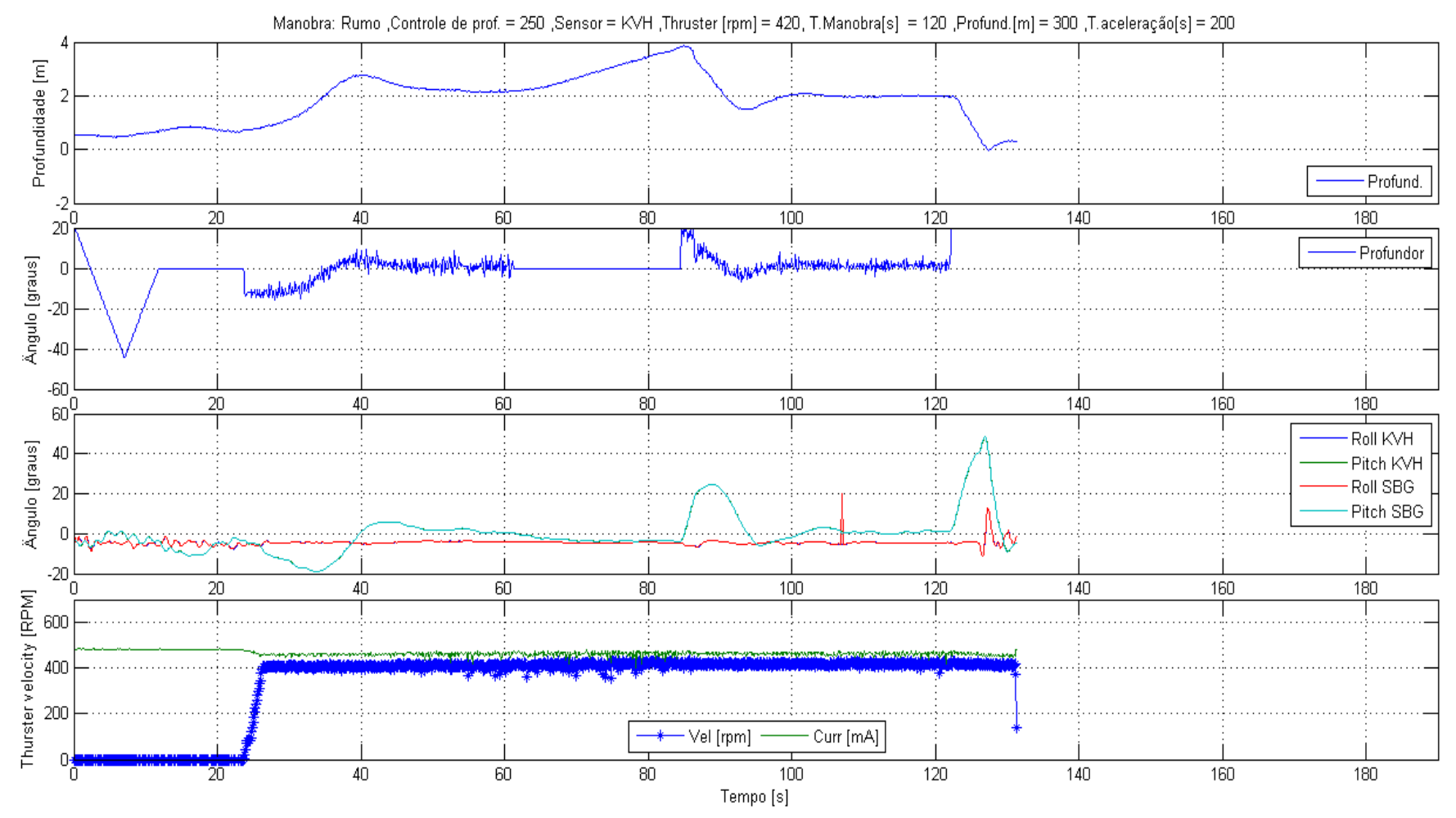

Figura 19 Dados de profundidade, ângulo de leme horizontal, atitude e rotação do hélice obtidos durante ensaios no mar 
A Figura 20 mostra os dados de atitude fornecidos por dois sensores diferentes durante o ensaio de zig-zag. Nota-se que ambos tem saídas muito similares, o que evidencia a correta aquisição dos sensores.
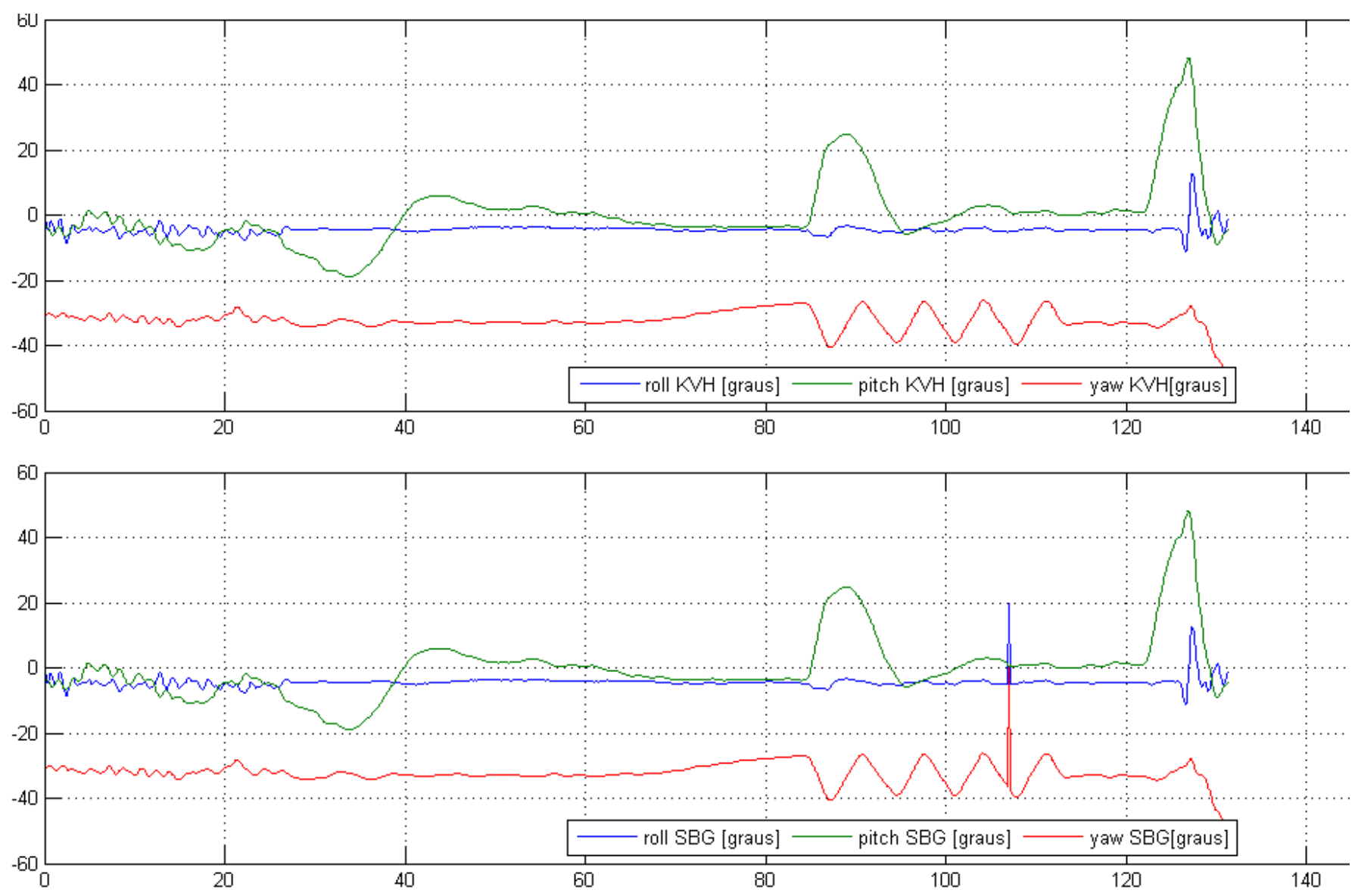

Figura 20 Dados de atitude obtidos durante ensaios no mar 
A Figura 21 apresenta os resultados de uma manobra de controle de rumo. Nota-se, pela leitura do DVL, que a velocidade em regime permanente já tinha sido alcançada no instante $\mathrm{t}=20 \mathrm{~s}$. Durante a manobra o rumo é mantido com um erro

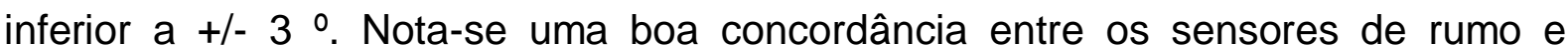
velocidade angular.

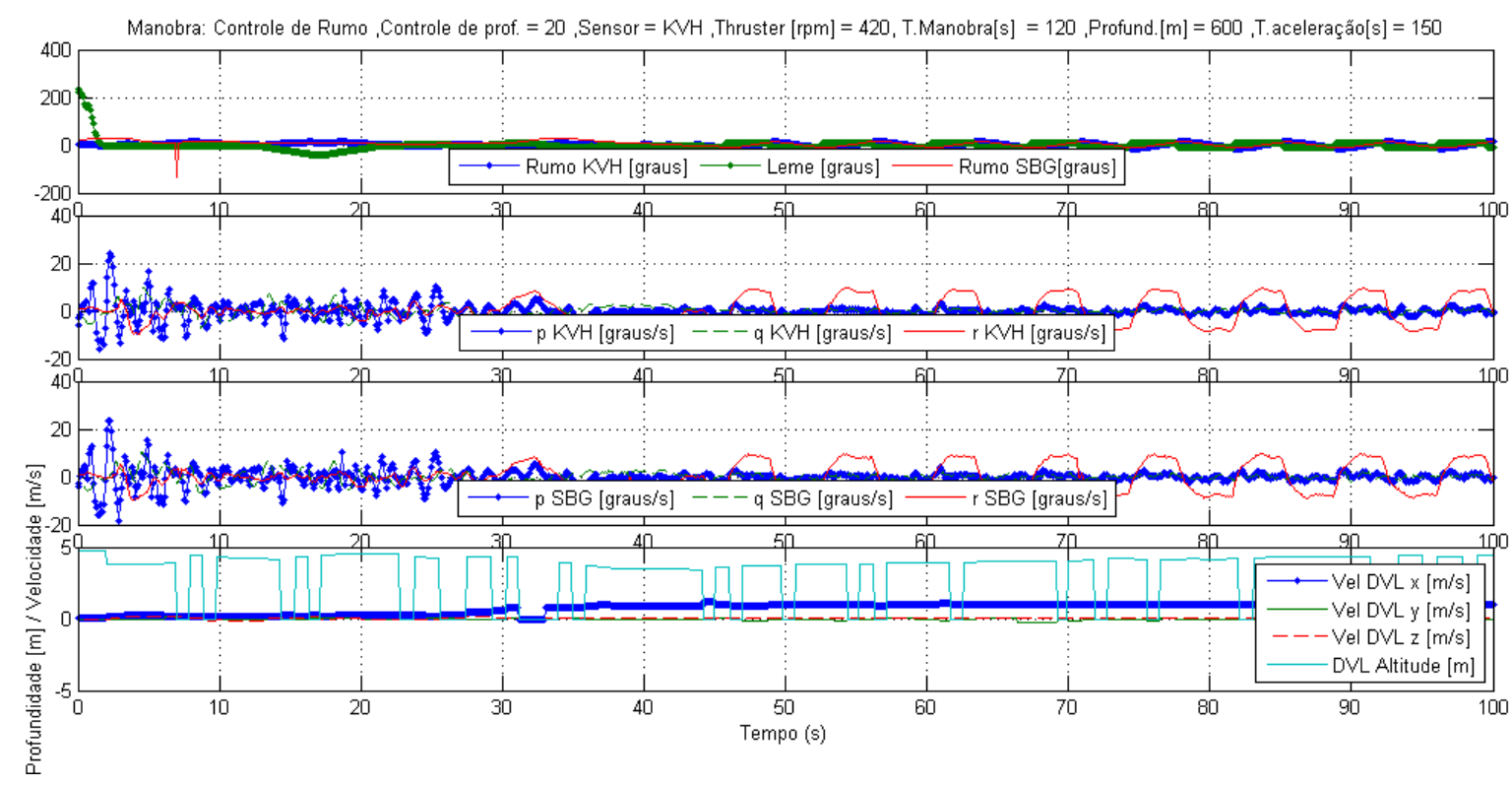

Figura 21 Manobra de controle de rumo 
A Figura 22 mostra uma manobra de teste de algoritmo de controle de profundidade. No instante $t=0$, o veículo está parado e mexe os lemes para avisar os operadores de que a manobra está começando. Isso se mostrou bastante interessante durante os ensaios como forma de comunicação, pois os operadores tomam ciência imediatamente de que o veículo recebeu a ordem de começar a manobra. No instante $\mathrm{t}=22 \mathrm{~s}$, o motor é acelerado e o veículo começa a controlar a profundidade. Nota-se que após um sobre sinal de quase meio metro, o veículo estabiliza na profundidade desejada depois cerca de 30 segundos.

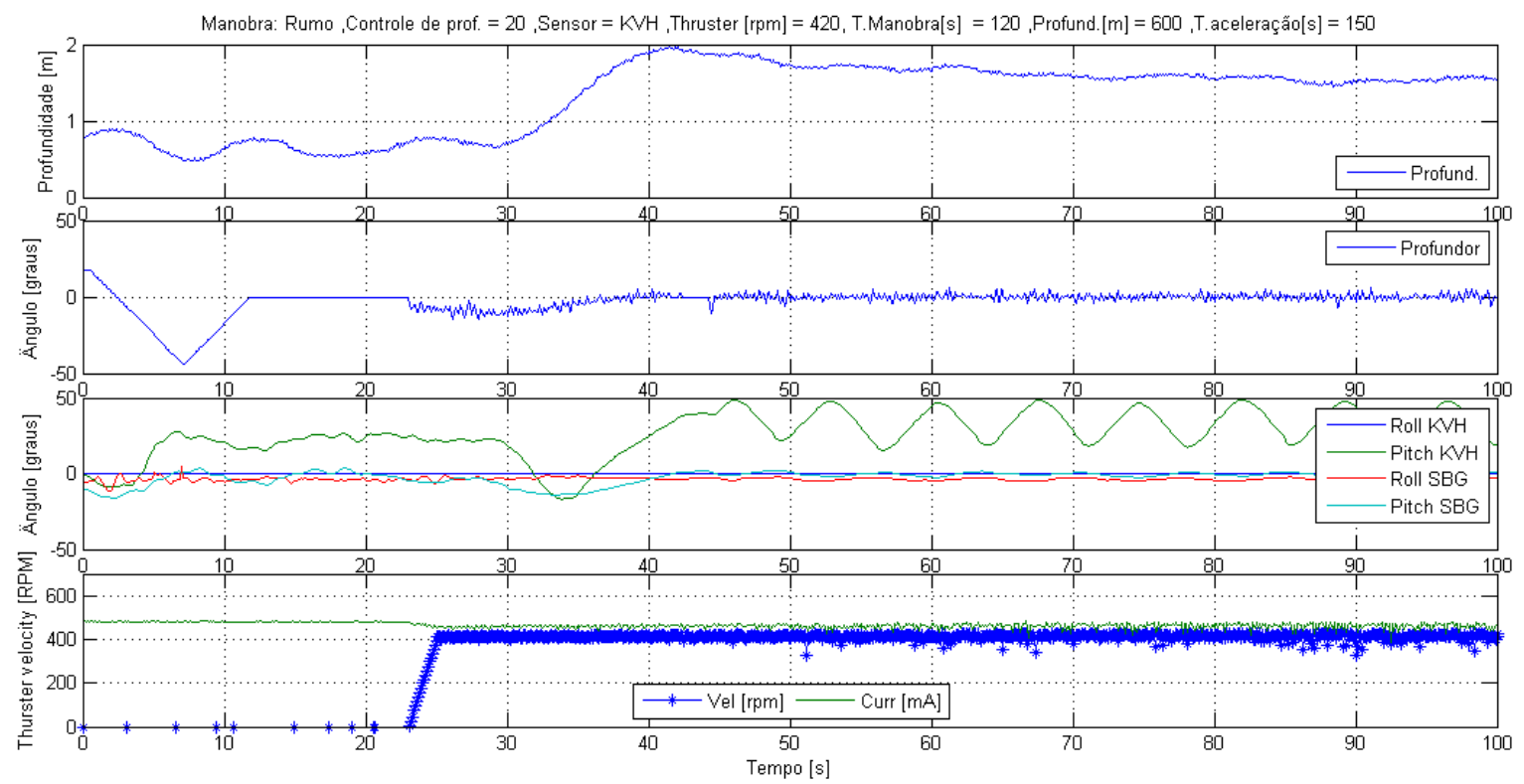

Figura 22 Manobra de controle de profundidade 
A manobra a seguir (Figura 23) é um zigzag, que é muito útil para estudos hidrodinâmicos. Nota-se, nesta versão que a bússola e a integração da saída do giroscópio têm uma boa concordância.

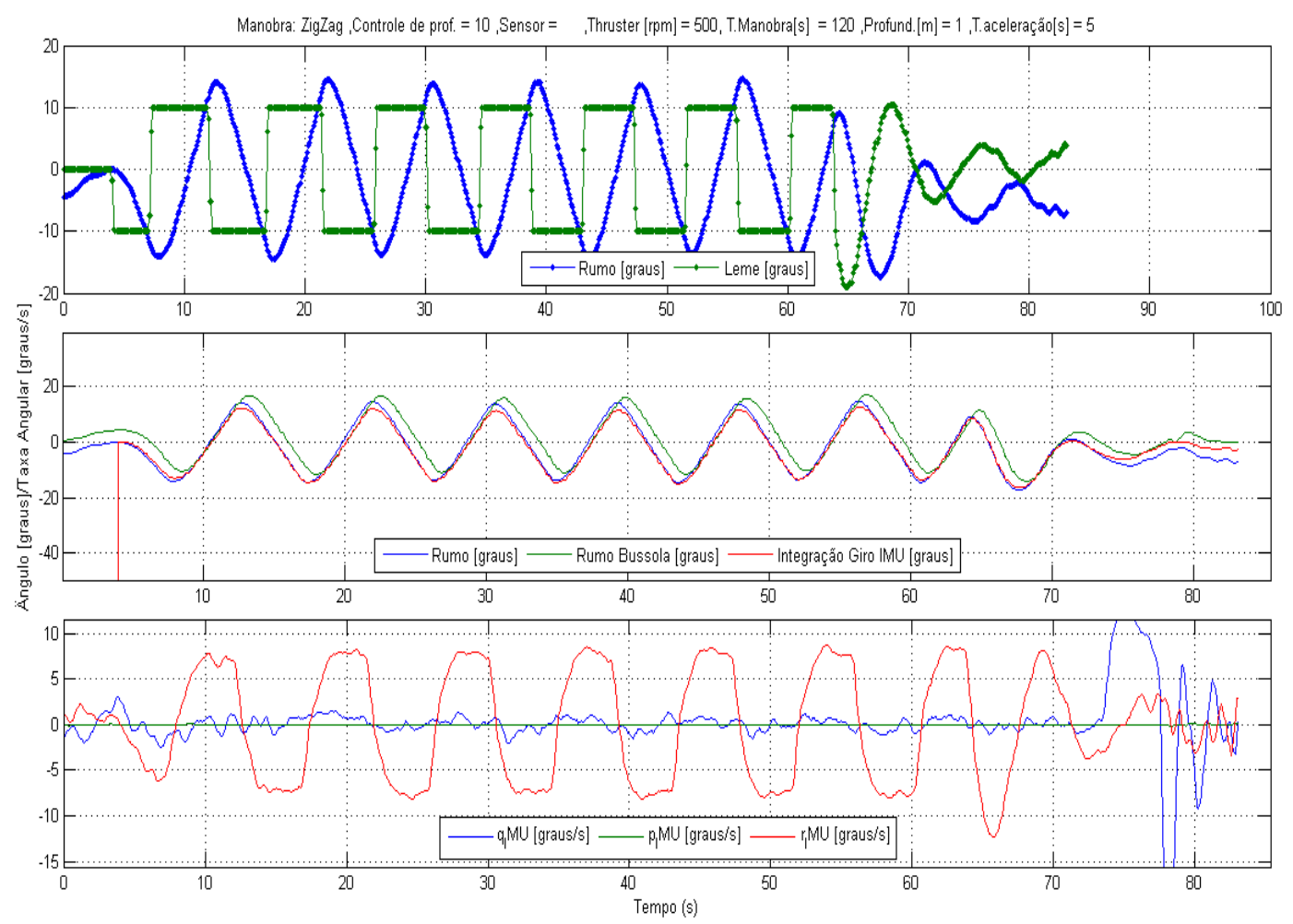

Figura 23 Manobra de zig-zag

Nota-se que a leitura da velocidade angular de guinada parece bastante regular. Pequenos sobressinais e oscilações em torno da provável velocidade angular de regime sugerem que um sistema de segunda ordem pode ser considerado para a modelagem da dinâmica da velocidade de guinada. 
Nesta última manobra, (Figura 24) foi feita uma guinada em U. Verifica-se que o veículo acelera do repouso e atinge a velocidade final em 10 segundos. $O$ controle de rumo assegura um rumo preciso no início da manobra, uma guinada com uma taxa quase constante (ângulo de leme constante) e por fim estabiliza em um rumo defasado de 180 graus do rumo inicial, apresentando pequenas oscilações em torno desse último trecho da trajetória.

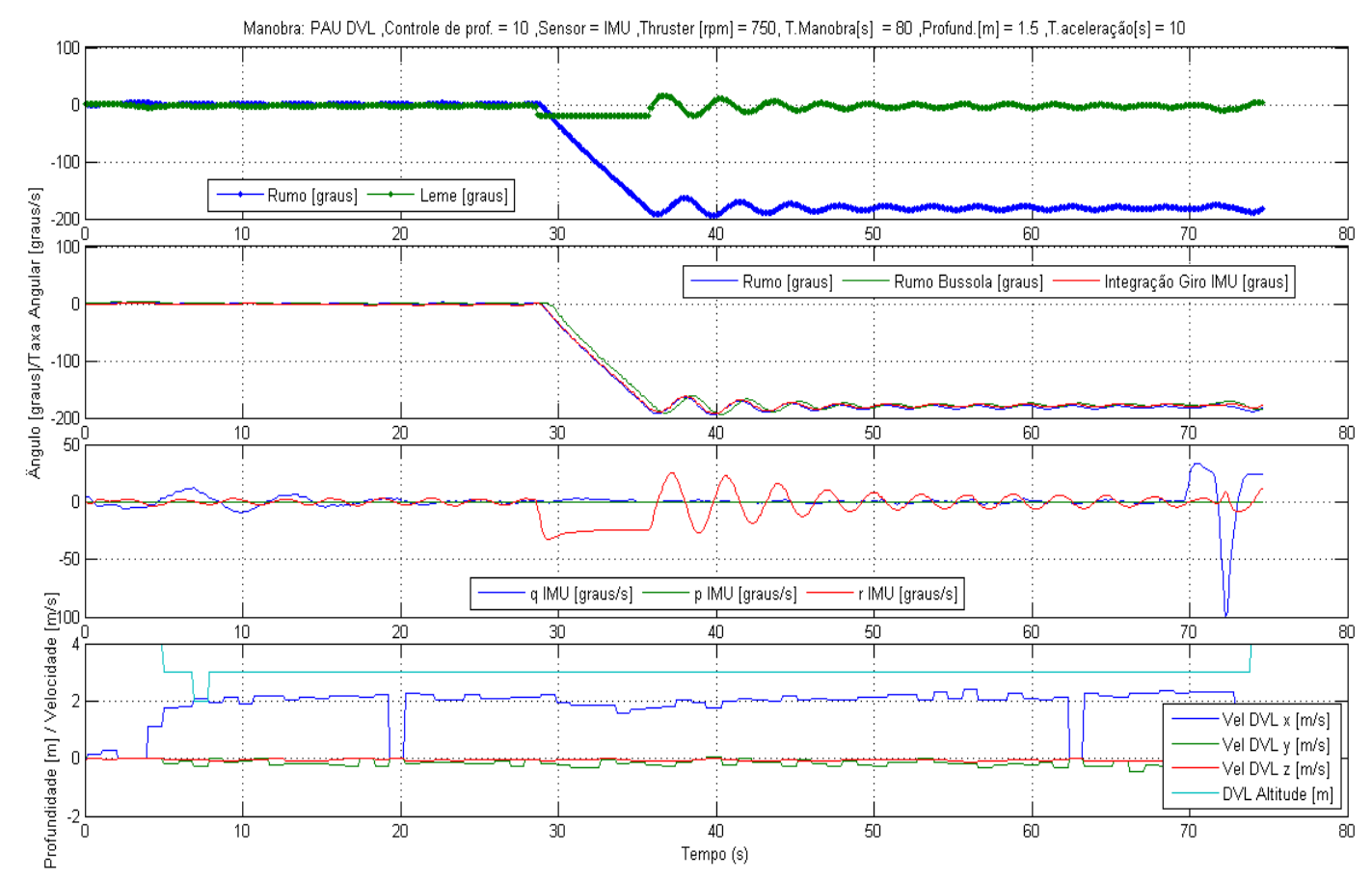

Figura 24 Manobra de guinada em U

A partir dessas manobras, pode-se notar um avanço na versão de 2013, desenvolvida por outros alunos, em relação à versão de 2010 , objeto do escopo deste trabalho. Mais sensores foram incorporados, manobras mais sofisticadas foram adotadas, o controle de profundidade foi aperfeiçoado e um novo padrão de comunicação com o usuário foi desenvolvido.

Tais melhorias demonstram a eficácia da metodologia adotada neste trabalho para assegurar e facilitar a continuidade do desenvolvimento da arquitetura de controle.

\subsection{Considerações finais}

O objetivo era criar uma arquitetura de controle flexível, extensível, modular e adaptável a novas aplicações por alunos de graduação em engenharia, conforme 
exposto na seção 4.3. O trabalho desenvolvido preencheu integralmente todos esses requisitos, conforme discutido em detalhe na seção 5.1 .

Foram feitos testes de validação em piscina nos quais todas as funcionalidades requeridas foram demonstradas. Adicionalmente, após o fim das tarefas de implantação da arquitetura do AUV Pirajuba, outros alunos continuaram criando novas funcionalidades e integrando ao sistema de controle, validando o requisito de continuidade de desenvolvimento.

Em uma entrevista informal com os alunos que continuaram 0 desenvolvimento, foi afirmado que todos tinham apenas conhecimento da linguagem C transmitido pelo curso de graduação. Os alunos afirmaram que o uso da arquitetura foi fácil e a estrutura se mostrou interessante devido a todos os módulos se comunicarem com a sharedmemory e nunca entre si. Apesar de isso parecer inconveniente em um primeiro momento, no longo prazo foi uma boa estratégia por simplificar e padronizar as interfaces de dados.

Houve dificuldades no que tange ao desenvolvimento de novos módulos, mas não em aspectos relacionados à arquitetura de software e de hardware, sendo estas dificuldades intrínsecas aos novos módulos desenvolvidos, tais como o novo módulo de comunicação de rádio. No hardware houve evoluções devido a novos requisitos de compactação, abandonando, para alguns nós, a caixa protetora. Entretanto, a ideia de empilhar as placas e empregar processadores ARM vem sendo mantida. 


\section{CONCLUSÕES}

Este capítulo visa apresentar um pouco da história do desenvolvimento deste trabalho e decorrentes conclusões.

Após um estudo do estado da arte em arquiteturas de controle aplicadas a AUVs e uma análise rápida das tendências nesse campo, foram estudadas as condições necessárias para que haja continuidade de desenvolvimento em um AUV concebido e construído em uma universidade.

Uma série de reflexões baseadas em experiências de outros professores e engenheiros mais experientes, motivou o estudo e aplicação da engenharia de sistemas, que é um arcabouço de técnicas e práticas de engenharia e estratégias de gerenciamento empregadas por instituições que lidam com sistemas complexos, tais como a NASA. Tais instituições lidam com os mesmos problemas encontrados pelo laboratório, que é o domínio dos prazos, do orçamento e da continuidade do desenvolvimento. Assim sendo, chega-se à conclusão de que desenvolver um sistema de controle de um AUV (e o AUV propriamente dito) é essencialmente um problema de engenharia de sistemas e não de um campo específico da engenharia.

O resultado é um resumo das práticas e técnicas da engenharia de sistemas que são aplicáveis ao ambiente universitário, bem como um exemplo prático da aplicação dessas técnicas no desenvolvimento de uma arquitetura de controle.

A arquitetura de controle, tal como foi concebida, envolve todas as funções típicas de um AUV, como planejamento de trajetória, navegação, guiamento e controle, funções da carga e monitoramento da saúde do AUV. Entretanto, este trabalho se restringiu à parte de controle dos atuadores, leitura dos sensores, manobras simples e algumas funções de monitoração da saúde do AUV, ficando as demais para desenvolvimentos futuros por parte de outros alunos.

Foi notado, durante o desenvolvimento do software de controle, que a decisão de empregar a linguagem $C$ foi muito feliz, pois possibilitou reusar códigos fonte disponibilizados de maneira gratuita na internet e de surpreendente qualidade. Esse aspecto acelerou muito o desenvolvimento dos módulos de acionamento dos controladores CAN e do sistema de arquivos, que de outra forma teriam tomado um tempo muito grande para serem desenvolvidos e talvez não atingissem o nível de qualidade atual. 
É interessante ressaltar que o padrão dos códigos fonte achados era, invariavelmente, quase que totalmente conforme a MISRA-C. Tal fato reduziu muito o trabalho de tornar o código conforme e evidenciou que reusar códigos fonte deve ser sempre uma alternativa a ser considerada.

O emprego do $\mu \mathrm{C}$-OSII também foi muito interessante pelo fato de ser um código aberto, o que garante que o laboratório terá sempre a capacidade de empregá-lo da maneira que Ihe convier, o que pode não ocorrer com um produto comercial que venha a ser descontinuado. Devido à sua simplicidade e abertura de código, esse sistema operacional é uma escola para alunos de graduação, que tipicamente não dominam ainda os conceitos de preempção e multiprocessamento e problemas relacionados, tais como deadlocks e livelocks. O seu funcionamento aparenta ser perfeito, não tendo sido notado qualquer problema durante todo o período de desenvolvimento, o que evidencia que esse sistema operacional realmente atinge requisitos para software aeronáutico.

Foram enfatizadas também, ao longo do trabalho, preocupações no sentido de aumentar a confiabilidade do sistema como um todo, levando em conta o ambiente ao qual um veículo submarino é exposto. No que tange ao hardware embarcado, essa preocupação se traduziu na preocupação de implementar um sistema mecanicamente robusto e na preocupação de isolar os equipamentos eletrônicos da atmosfera do meio ambiente. Para o software, foi seguido um certo rigor em seu desenvolvimento, de modo a manter as características de tempo real, a saber, resposta temporal, simultaneidade, previsibilidade e robustez. No sentido de manter o código portável foi seguido até certo ponto o padrão MISRA C.

$O$ desenvolvimento de código segundo padrões de programação tem uma necessidade de preparação prévia e requer algum esforço para a memorização de todas as regras. Mas o resultado é surpreendentemente positivo, pois evita que uma série de erros, muitas vezes difíceis de serem localizados por simples inspeção, ocorra, economizando tempo. Além disso, o código fica com uma apresentação bem mais agradável e legível, facilitando a leitura e a inspeção pelo próprio programador. Em projetos onde mais de um programador terá que empregar o código, conclui-se que o uso rigoroso de padrões de codificação é absolutamente necessário.

Uma possibilidade ainda não explorada é a expansão do sistema com um hardware compatível com o Real Time Workshop da Mathworks com capacidade para se comunicar em uma rede CAN. Dessa forma seria possível, com pequeno 
esforço de desenvolvimento e alta qualidade de software (compatível com o barramento CAN), permitir a interação do sistema com filtros (por exemplo, de Kalman) para obtenção precisa de dados, como posição, orientação e velocidade.

Por fim, a conclusão mais importante deste trabalho é que o desenvolvimento de um sistema complexo é muito mais um problema gerencial do que um problema técnico e que a solução técnica adotada deve sempre estar de acordo com as restrições gerenciais, pois é muito fácil mudar uma tecnologia, mas o ser humano e as instituições não podem ser mudados no escopo de um projeto. Um determinado recurso tecnológico pode ser possuidor de vantagens técnicas enormes, porém, para que ele seja virtualmente inútil, basta que tenha um dos seguintes atributos: excessivamente caro; disponibilidade reduzida ou tempo de familiarização muito longo. 


\section{AGRADECIMENTOS}

Em primeiro lugar, eu agradeço ao meu orientador, professor doutor Ettore Apolônio de Barros, pelas oportunidades de fazer uma iniciação científica e um trabalho de mestrado em um assunto prático, propiciando um crescimento profissional que teve reflexos positivos na minha carreira.

Agradeço também aos meus veteranos do laboratório, Giovani Amianti e João Lucas Dozzi Dantas pelos conhecimentos a mim transmitidos durante todos esses anos.

Por fim, gostaria de agradecer aos colegas Rodrigo Telles da Silva Vale e Lucas Machado de Oliveira pela ajuda nos trabalhos do laboratório e pela continuidade do desenvolvimento, que propiciaram a validação final deste trabalho. 


\section{APÊNDICE A - CONVENÇÃO DE NOMES E DEFINIÇÕES}

- Análise [45]: Por meio de modelos matemáticos ou técnicas analíticas, predizer se um determinado projeto atende às expectativas do cliente.

- Arquitetura de controle: Refere-se à filosofia geral empregada para o desenvolvimento do sistema de controle de um veículo, por exemplo, arquitetura hierárquica ou arquitetura heterárquica. Para o caso específico de um AUV, que precisa ter um certo grau de inteligência, abrange a organização da tomada de decisão, a arquitetura de hardware e a arquitetura de software.

- Arquitetura de Hardware: é a solução tecnológica adotada para implementar uma dada arquitetura de controle, abrangendo a eletrônica, a parte elétrica, as placas de circuito impresso, redes de dados e os processadores.

- Arquitetura de Software: é a solução em termos de código desenvolvido e que reflete o comportamento do sistema. Envolve a organização geral do código, a filosofia de desenvolvimento (orientação a objetos, linguagem estruturada) e a linguagem de programação utilizada.

- Árvore funcional: É a decomposição das funcionalidades presentes em cada sistema e respectivos subsistemas.

- Árvore do produto: É a decomposição dos componentes empregados em um sistema e respectivos subsistemas.

- Inspeção [45]: Exame visual de um produto ou documento.

- Checksum: um ou dois bytes que contém a soma ou o ou exclusivo de todos os bytes que compõem a mensagem.

- Classe: É um tipo de objeto. Trata-se de uma construção de código que permite criar instâncias (ou objetos) desse tipo. Costuma incluir atributos e métodos.

- Componente: Conjunto de objetos que partilham características ou finalidades semelhantes.

- Demonstração [45]: Mostrar que o produto acabado atinge o requisito. Geralmente é uma confirmação básica do desempenho, diferente do teste pela falta de obtenção de dados detalhados.

- Engenharia de sistemas: campo da engenharia criado para lidar com a desenvolvimento de sistemas complexos e multidisciplinares.

- Objeto: Usado neste trabalho no contexto de programação orientada a objetos, cuja principal característica é o encapsulamento de atributos e métodos em uma mesma porção de código, sendo que apenas os métodos públicos ficam disponíveis para usuários externos. A aplicação da orientação a objetos não depende necessariamente do uso de uma linguagem orientada a objetos, sendo possível empregar linguagens procedurais no desenvolvimento orientado a objetos. No entanto, uma linguagem orientada a objetos facilita 0 desenvolvimento.

- Requisitos funcionais: são as funcionalidades desejadas de um equipamento.

- Requisitos não funcionais: são restrições impostas sobre o comportamento de um sistema de maneira a evitar efeitos colaterais indesejáveis, como acidentes. 
- Sistema: Um "sistema" é uma construção ou a agrupamento de elementos diferentes que, em conjunto produzem resultados não podem ser obtidos pelos elementos sozinhos. Os elementos, ou partes, podem incluir pessoas, hardware, software, instalações, políticas e documentos, isto é, tudo o que for necessário para produzir resultados a nível de sistema. Os resultados ao nível do sistema incluem qualidades, propriedades, características, funçionalidades, comportamento e desempenho. O valor acrescentado pelo sistema como um todo, além das contribuições isoladas de cada parte, é criado principalmente pela relação entre as partes, isto é, como elas são interligadas [45].

- Teste [45]: Uso do produto acabado para obter dados detalhados que são necessários à verificação de desempenho. Testes produzem dados para cada requisito sob condições controladas e é a técnica de verificação e validação que mais demanda esforço.

- Tick: unidade de tempo que o sistema operacional espera para verificar se existe uma tarefa de maior prioridade pronta para ser ativada. Também se aplica à rotina chamada para fazer essa verificação.

- Validação [45]: atividade feita para averiguar se um determinado projeto conceitual, protótipo ou produto acabado está de acordo com as necessidades do cliente. Pode ser feita por meio de análise, inspeção, demonstração e teste.

- Verificação [45]: atividade feita para comparar um determinado sistema com suas especificações, ou um determinado documento com os suas fontes. É uma checagem feita internamente para garantir que o processo foi executado de maneira consistente. Pode ser feita por meio de análise, inspeção, demonstração e teste. 


\section{BIBLIOGRAFIA}

[1]. AMIANTI, G., "Arquitetura de software aviônico de um VANT com requisitos de homologação", 2008, 278 p. Dissertação (Mestrado) Escola Politécnica da Universidade de São Paulo, Universidade de São Paulo, São Paulo, 2008.

[2]. SMITH, S. M., "An Approach to Intelligent Distributed Control for Autonomous Underwater Vehicles", Proceedings of the IEEE Symposium on Autonomous Underwater Vehicle Technology, p 105-111, 1994.

[3]. VALAVANIS, K. P., "Control architectures for autonomous underwater vehicles", IEEE Control Systems Magazine, p 48-64, Dec 1997.

[4]. OLIVEIRA, P. ET AL., "Mission Control of the MARIUS AUV System Design Implementation and Sea Trials", International Journal of Systems Science - IJSySc, 1998

[5]. ORTIZ, A., "Improving the safety of AUVs", OCEANS '99 MTS/IEEE, v. 2, p. 979-984, 1999.

[6]. RIDAO, P. ET AL., "On AUV control architecture", IEEE International Conference on Intelligent Robots and Systems, v 2, p 855-860, 2000.

[7]. OLIVER, G. et al., "RAO: a low cost AUV for testing", OCEANS 2000 MTS/IEEE Conference and Exhibition, v. 1, p 397-401, 2000.

[8]. HAGEN, P.E., "AUV/UUV mission planning and real time control with the HUGIN operator system", Oceans Conference Record (IEEE), v 1, p 468-473, 2001.

[9]. SMITH, S. M., et AL, "The Morpheus ultramodular autonomous underwater vehicle", IEEE Journal of Oceanic Engineering, v 26, n 4, p 453-465, October 2001.

[10]. MARCO, D. B., HEALEY, A. J., "Command, Control and Navigation Experimental Results with the NPS ARIES AUV", IEEE Journal of Oceanic Engineering, v. 26, N. 4, p 466-476, 2001.

[11]. RIDAO, P. ET AL, "O2CA2, a new object oriented control architecture for autonomy: The reactive layer", Control Engineering Practice, v 10, $n$ 8, p 857-873, August 2002

[12]. SIBENAC, M. "Modular AUV for routine deep water science operations", Oceans Conference Record (IEEE), v 1, p 167-172, 2002. 
[13]. EVANS, JONATHAN, "AUTOTRACKER: AUV embedded control architecture for autonomous pipeline and cable tracking", Oceans Conference Record (IEEE), v5, p 2651-2658, 2003.

[14]. SONG, F., AN, P. E., FOLLECO, A., "Modeling and Simulation of Autonomous Underwater Vehicles: Design and Implementation", Journal of Oceanic Engineering, IEEE, vol. 28, no. 2, 2003.

[15]. T.W. KIM, J. YUH, "Development of a real-time control architecture for a semi-autonomous underwater vehicle for intervention missions", Control Engineering Practice, v 12, n 12 SPEC. ISS., p 1521-1530, December 2004.

[16]. EL JALAOUI, A., "A control architecture for contextual tasks management: Application to the AUV Taipan”, Oceans 2005 - Europe, v 2, p 752-757, 2005.

[17]. TANGIRALA, S., "Hybrid-model based hierarchical mission control architecture for autonomous underwater vehicles", Proceedings of the American Control Conference, v 1, p 668-673, 2005.

[18]. NASAHASHI, K., "Underwater Volcano Observation by Autonomous Underwater Vehicle", OCEANS 2005 - EUROPE, 557 - 562 VOL. 1, 2005.

[19]. WANG, I. et al., "Modular Hardware Infrastructure for Autonomous Underwater Vehicles", OCEANS 2005. Proceedings of MTS/IEEE, v. 3, p 2652-2655, 2005.

[20]. PALOMERAS, N., "Mission Control System for Dam Inspection with an AUV", Intelligent Robots and Systems, 2006 IEEE/RSJ International Conference on, 2006.

[21]. MARTIN, S. C. ET AL., "A mission controller for high level control of autonomous and semi-autonomous underwater vehicles", OCEANS 2006, P. $1-6,2006$.

[22]. WATANABE, K., "An AUV Based Experimental System for the Underwater Technology Education”, OCEANS 2006-Asia Pacific, p 1-7, 2007.

[23]. ZHANG, H. W. et al., "CAN bus based control system for autonomous underwater vehicle", Jiqiren/Robot, v. 28, n. 4, p 448-452, 2006. Em língua chinesa.

[24]. CUFF, T. R., "Support Platform and Communications to Manage Cooperative AUV Operations", OCEANS 2006 - Asia Pacific, p 1 - 8, 2006.

[25]. WANG, Y., "Research on Test-platform and Condition Monitoring Method for AUV", Mechatronics and Automation, Proceedings of the 2006 IEEE International Conference on, p 1673 - 1678, 2006. 
[26]. D. RIBAS et Al., "ICTINEU AUV Wins the First SAUC-E Competition", 2007 IEEE International Conference on Robotics and Automation ICRA'07, p 151-156, 2007.

[27]. JI, S.H., "Development of an open architecture controller for a commercial AUV", International Symposium on Underwater Technology, UT 2007 - International Workshop on Scientific Use of Submarine Cables and Related Technologies 2007, p 568-573, 2007.

[28]. M. CARRERAS, "Design of a mission control system for an AUV", International Journal of Control, Volume 80, Issue 7 July 2007 , pages 993 - 1007, 2007.

[29]. BENJAMIN, M. R. et al., "Autonomous control of an autonomous underwater vehicle towing a vector sensor array", Proceedings - IEEE International Conference on Robotics and Automation, ICRA'07, p 45624569, 2007.

[30]. ACOSTA, G. G., "Low-cost Autonomous Underwater Vehicle for pipeline and cable inspections", International Symposium on Underwater Technology, UT 2007 - International Workshop on Scientific Use of Submarine Cables and Related Technologies 2007, p 331-336, 2007.

[31]. HASSAAN KHALID, M. et al., "FATCAR-AUV: Fault tolerant control architecture of AUV", Proceedings of International Bhurban Conference on Applied Sciences and Technology, IBCAST, p 161-167, 2007.

[32]. SANGEKAR, M., "Hardware architecture for a modular autonomous underwater vehicle STARFISH", Proceedings of IEEE OCEANS 2008, $p$ $1-8,2008$.

[33]. CHITRE, M., "DSAAV - A distributed software architecture for autonomous vehicles", OCEANS 2008, p 1-10, 2008.

[34]. MCGANN, C., "A deliberative architecture for AUV control", Proceedings - IEEE International Conference on Robotics and Automation, ICRA 2008, p 1049-1054, 2008.

[35]. JUAN, L., "Research on hierarchical control architecture for autonomous underwater vehicle", Proceedings of 2008 IEEE International Conference on Mechatronics and Automation, ICMA 2008, p 483-487, 2008.

[36]. ZHANG, L. et al., "Design and experiment of automatic pilot for long range AUVs", 2008 3rd IEEE Conference on Industrial Electronics and Applications, p 1824-1827, 2008.

[37]. LEI, Z., "Motion control of AUV based on embedded operation system", 4th IEEE Conference on Industrial Electronics and Applications, ICIEA 2009, p 1167-1172, 2009. 
[38]. BIAN, X. Q., "Research of autonomous control based on multi-agent for AUV", 2009 International Workshop on Intelligent Systems and Applications, ISA 2009, p 1 - 4, 2009.

[39]. WOITHE, H. C. and Kremer, U., "A Programming Architecture for Smart Autonomous Underwater Vehicles", The 2009 IEEE/RSJ International Conference on Intelligent Robots and Systems, p 4433 4438, 2009.

[40]. BARISIC, M., "A MOOS-based online trajectory re-planning system for AUVs", OCEANS '09 IEEE Bremen: Balancing Technology with Future Needs, p $1-6,2009$.

[41]. EICKSTEDT, D. P., SIDELEAU, S. R., "The Backseat control architecture for autonomous robotic vehicles: A case study with the Iver2 AUV", Marine Technology Society Journal, v 44, number 4, p 42 -54, 2010.

[42]. IEC "Functional Safety of Electrical/Electronic/Programmable Electronic Safety-related Systems" IEC61508, IEC, 2010.

[43]. SCHLAGER, J. "Systems engineering: key to modern development". IRE Transactions EM-3 (3): p 64-66, 1956

[44]. ARTHUR D. HALL "A Methodology for Systems Engineering" $1^{\text {st }}$ ed., Princeton, New Jersey, Van Nostrand Reinhold, 1962, 478 p.

[45]. NASA "NASA Systems Engineering Handbook", Revision 1, NASA/SP-2007-6105, NASA, 2007

[46]. EL JALAOUI, A.;ANDREU, D.; JOUVENCEL, B., "Contextual management of tasks and instrumentation within an AUV control software architecture", IEEE International Conference on Intelligent Robots and Systems, P 3761-3766, 2006.

[47]. VOSS, W., "A Comprehensible Guide to Controller Area Network", $2^{\text {nd }}$ ed., Greenfield, Massachusetts, United States of America, Copperhill Media Corporation, 2005, $176 \mathrm{p}$.

[48]. OKURA, J. H., "Metodologia de qualificação de componentes eletrônicos", 1995, 176 p. Dissertação (Mestrado) - Faculdade de Engenharia Elétrica, Universidade Estadual de Campinas, Campinas, 1995.

[49]. TEXAS INSTRUMENTS INC., "PCB Design Guidelines for Reduced EMI", Application Report, 1999, 23 p.

[50]. SCHREINER, A., "Object Orientated Programming in ANSI-C", $1^{\text {st }}$ ed., Hollage, 1993, $221 \mathrm{p}$. 
[51]. QUIGLEY, M., ET AL, "ROS: an open-source Robot Operating System", ICRA workshop on open source software. VOL. 3. NO. 3.2. 2009.

[52]. LABROSSE, J. J., " $\mu$ C/OS-II, The Real-Time Kernel”, $2^{\text {nd }}$ ed., CMP Books, Kansas - USA, 2002, 303 p. 